Universidade de São Paulo Instituto de Arquitetura e Urbanismo Programa de Pós-graduação em Arquitetura e Urbanismo

\title{
Ouvir outros espaços Entornos híbridos, interfaces sonoras em espaços públicos
}

Dissertação de Mestrado

Luciana Santos Roça

Orientador: Prof. Assoc. Dr. Marcelo Tramontano 


\section{Ouvir outros espaços:}

Entornos híbridos, interfaces sonoras em espaços públicos

Luciana Santos Roça

Dissertação apresentada ao Programa de PósGraduação do Instituto de Arquitetura e Urbanismo da Universidade de São Paulo como parte dos requisitos para obtenção do título de Mestre em Arquitetura e Urbanismo.

Orientador: Prof. Associado Dr. Marcelo Tramontano 
AUTORIZO A REPRODUÇÃO TOTAL OU PARCIAL DESTE TRABALHO, POR QUALQUER MEIO CONVENCIONAL OU ELETRÔNICO, PARA FINS' DE ESTUDO E PESQUISA, DESDE QUE CITADA A FONTE.

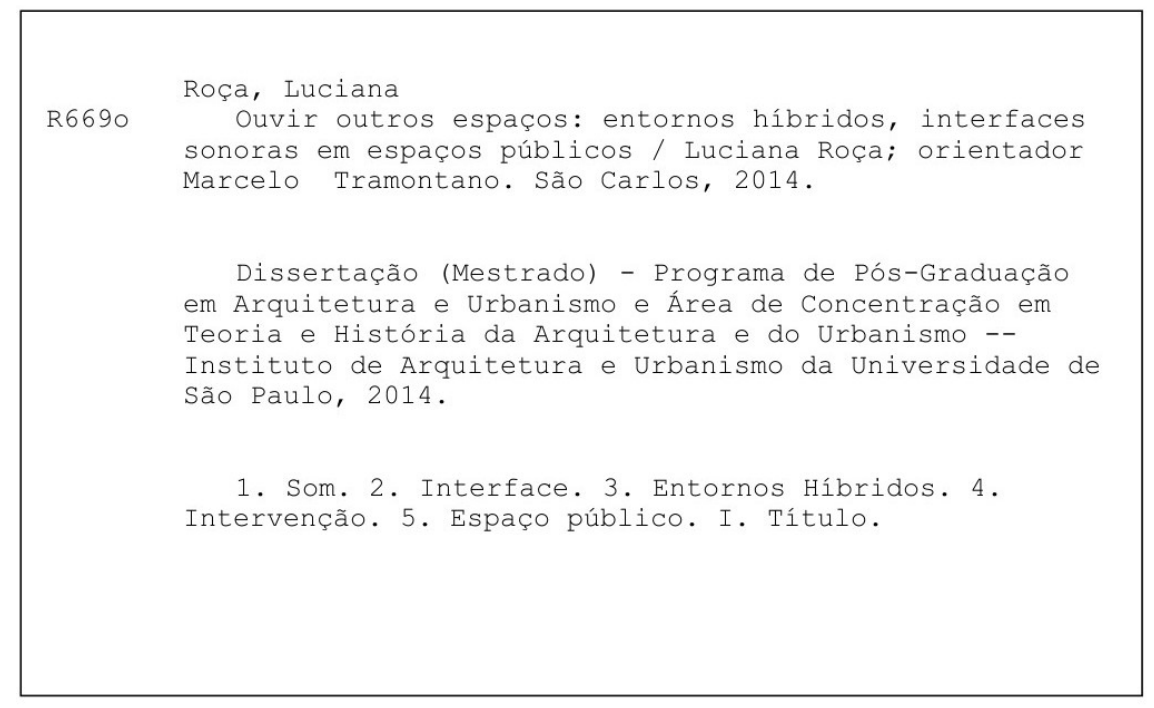




\section{FOLHA DE JULGAMENTO}

Candidata: Bacharela em Imagem e Som Luciana Santos Roça.

Título da dissertação: "Ouvir outros espaços: entornos híbridos, interfaces sonoras em espaços públicos".

Data da defesa: 30/04/2014.

Comissẳo Julgadora:

Prof. Dr Anarceld Claudio tramontano (orientador)

(Instituto de Arquitetura e Urbanismo - USP)

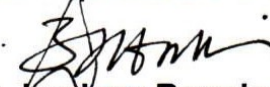

Profa. Dra. Kuciana Bongiovanni Martins Schenk (Instituto de Arquitetura e Urbanismo - USP)

Profa. Dra. Suzana Reck Miranda

(Departamento de Artes e Comunicação/UFSCar)
Resultado:
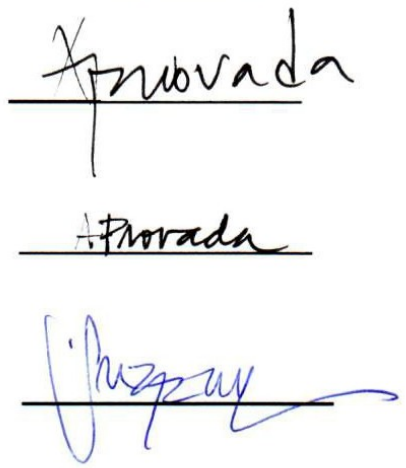

Presidente e Coordenador do Programa de Pós-Graduação em Arquitetura Urbanismo: Professor Associado Márcio Minto Fabricio 

A todos meus mestres, formais e informais, que me ensinaram a ouvir. 



\section{Agradecimentos}

Tantas inspirações, sonhos, ideias, aprendizados, além de todo o amadurecimento pessoal e acadêmico são contidos nessa jornada, ao mesmo tempo longa e curta, mas certamente muito intensa e que não cabe nessa dissertação.

Certamente também não caberiam nessas poucas páginas de agradecimento os nomes de todas as pessoas, compositores, bichos, sons e coisas aos quais devo agradecimento. Foram muitas vivências cruzadas e caminhos alternativos que fazem parte desse resultado final. Por isso, acabo dedicando essa dissertação a todos meus mestres que me ensinaram a ouvir e ajudaram a aumentar minha sensibilidade e reflexão. São aqueles que participaram da minha educação formal e também informal, naquelas horas em que uma simples fala ou ato oferecem um insight imenso.

Ao Prof. Assoc. Dr. Marcelo Tramontano, por me dar oportunidades para ampliar minhas visões de mundo e por me auxiliar a compreender melhor assuntos tão diversos.

A todos os pesquisadores do Nomads.usp, os quais a formalidade dos títulos aqui escritos nunca significou inacessibilidade ou hierarquia, mas sim grandes trocas e compartilhamentos. São companheiros de pesquisa pelos quais tenho grande admiração, em especial Profa. Dra. Anja Pratschke e Profa. Dra. Varlete Benevente; Dra. Denise Mônaco dos Santos, Dra. Mayara Dias, Msc. Cynthia Nojimoto, Msc. Daniel Paschoalin, Msc. Elza Miyasaka, Msc. João Paulo Soares, Msc. Felipe Anitelli, Msc. Gilfranco Alves, Msc. Priscilla Marchetto, Msc. Sandra Soster, Raimundo Santos, e Theodoro Monteleone de Oliveira. Fico feliz por ter cruzado seus caminhos pela combinação frutífera de amizade com pesquisa, risos com reflexão.

A todos os participantes do Projeto Territórios Híbridos, projeto tão importante para essa pesquisa e para minha formação pessoal. Dos bastidores aos participantes; àqueles das horas do café, aos que carregaram trilhos comigo e àqueles das horas de abordagem e que aceitaram conversar com uma estranha.

À Fundação de Amparo à Pesquisa do Estado de São Paulo (FAPESP), pela concessão da bolsa de mestrado que possibilitou o desenvolvimento dessa pesquisa. 
Aos Professores e Funcionários do Instituto de Arquitetura e Urbanismo da Universidade de São Paulo, que tangenciaram o processo de pesquisa e possibilitaram seu desenvolvimento. Ao Prof. Dr. Fábio Duarte e à Profa. Dra. Luciana Bongiovanni M. Schenk, pelos esclarecimentos dados na banca de qualificação que ajudaram a construir esse trabalho final, e à Profa. Dra. Suzana Reck Miranda por participar do exame final.

Aos meus colegas e amigos que conviveram sonoramente comigo no estúdio Casablanca Sound, em meio a bicicletas, dinossauros e tantos diálogos alheios a serem editados. Principalmente Luiz Adelmo por todos os ensinamentos sobre o potencial que o som tem, ajudando-me a ver claramente a aliança de teoria e prática e por me dar oportunidade de explorar isso e de amadurecer tantas ideias que me ajudaram a encontrar o meu objeto de pesquisa e revigorando minha relação com o som.

A todos os meus amigos que me incentivaram e vibraram junto comigo, sempre me lembrando que não se deve ser tão sério. Especialmente os amigos André Marques, Anderson Marques, Fátima Machado, Gabriela Callile, Ian Mazzeu e Victor Canela. Ao Emerson Santos, por todo incentivo, interesse, discussões reflexivas e jantares gourmet no fim dessa etapa.

À minha família e com muito carinho aos meus amados pais que, por mais tortuosos sejam os caminhos que escolho, permanecem ao meu lado me dando forças para continuar. 


\section{Resumo}

Esta pesquisa investiga relações entre som e espaço, discutindo conceitos referentes à justaposição de entornos sonoros e físicos. Para tanto, a abordagem da pesquisa reside na discussão dessas relações a partir do uso de interfaces sonoras que promovam escuta coletiva em espaços públicos, constituindo entornos híbridos e proporcionando diferentes apreensões do espaço. Tratando-se de uma pesquisa multidisciplinar, o estudo busca aproximar as disciplinas da Arquitetura e Urbanismo e Estudos de Som. A investigação teórica contextualiza e fornece conceitos de ambos campos disciplinares sobre a função do som enquanto elemento do espaço. A partir dos conceitos trabalhados, são realizadas leituras de intervenções sonoras e a análise do experimento da pesquisa, que inclui a realização de uma intervenção. A intervenção consta no relocamento do conjunto de sons do trem para uma praça pública, de forma a dialogar com seu contexto e dinâmicas sociais e históricas, contribuindo para o surgimento de diferentes interpretações e reflexões das pessoas presentes. Dessa forma, reforça-se a importância da associação entre teoria e prática, que se constitui como procedimento fundamental para a investigação sobre o assunto.

Som - Interface - Entornos Híbridos - Intervenção - Espaço público 



\title{
Listen to other spaces:
}

Hybrid environments, sound interfaces in public spaces

\begin{abstract}
This research investigates sound and space relationships, discussing concepts referred to the juxtaposition of sonic and physical environments. So, the research approach lies in the discussion of these relationships based on the use of sound interfaces which promote collective listening in public spaces, producing hybrid environments and promoting different apprehensions of space. As it is a multidisciplinary research, the study seeks to approach Architecture, Urbanism and Sound Studies disciplinary fields. Theoretical investigation contextualizes and provides concepts from both disciplinary fields on the role of sound as an element of space. From the developed concepts, readings on sound interventions are made as well as the analysis on the research's experiment, which includes the accomplishment of an intervention. The intervention is based on the relocation of a set of trains sounds to a public square, engaging with its context and social and historical dynamics, contributing to the appearance of different interpretation and thinking on the people present. Thus, the importance of the association between practice and theory is reinforced, which is fundamental for researching this subject.
\end{abstract}

Sound - Interface - Hybrid Environments - Intervention - Public Space. 



\section{Sumário}

Introdução

Capítulo I - Elaborando entornos híbridos

11

Reverberações

13

Difusão: Pluralidade de ruídos

20

Como soa?

25

Ressonâncias: Considerações sobre o espaço

32

Difração: Uso de interfaces

39

Reflexão: Consequências dadas pelo aspecto tecnológico

46

Propagação: Ouvindo junto

49

\section{Capítulo II - Práticas Sonoras:}

\section{leituras de um campo extenso}

55

Direcionamento qualitativo dado pelas interfaces sonoras 60

Engajamento através da escuta e participação 63

Transformações quanto aos entornos sonoros 64

21 balançoires, Daily Tous Les Jours, 2011-2013. 68

Sound Island [Arche Sonore], Bill Fontana, 1994. 73

Tiefdruckgebiet, Carl Schilde e Anselm Nehls [Heavylistening], 2011-2012 79

Voz Alta, Raphael Lozano-Hemmer, 2008.

Sons do invisível 88 
Capítulo III - outros sons, mesmo espaço? $\quad 91$

Três elementos em "Reverberação Urbana" 96

Caminhando para ouvir, ouvindo para entender 102

Soundwalk: construção de elementos sobre o entorno sonoro acústico 103

$\begin{array}{ll}\text { Entorno sonoro: Praça do Mercado } & 107\end{array}$

Entorno sonoro: CDHU $\quad 112$

Praça do Mercado e CDHU: diferenças sonoras $\quad 115$

Reverberação Urbana: o trem intervém na praça 117

Considerações sobre as entrevistas e métodos de registro 118

Direcionamento qualitativo dado pelas interfaces sonoras $\quad 122$

Quanto ao fator tecnológico: visibilidade da interface $\quad 128$

Reações do público 132

Quanto às relações de escuta 134

Além do som: o som como elemento representativo 137

No ouvido do outro: a questão do CDHU 141

$\begin{array}{ll}\text { Considerações } & 143\end{array}$

$\begin{array}{lr}\text { Conclusões } & 149\end{array}$

$\begin{array}{ll}\text { Referências } & 157\end{array}$

$\begin{array}{lr}\text { Anexos } & 169\end{array}$ 


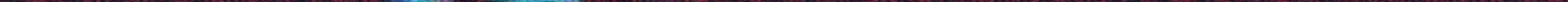




\section{Introdução}

A investigação para se desvendar possibilidades e especificidades nas relações entre som e espaço tem sido realizada tanto por artistas quanto acadêmicos, por vezes pesquisadores que também incluem a prática artística em seus trabalhos. O campo disciplinar da Arquitetura e Urbanismo possui papel fundamental em discutir o tema sob a perspectiva do espaço, da acústica; outras vezes, claramente não menos importantes, com estudos sobre processos de leitura urbana e sobre a influência das tecnologias de informação e comunicação sobre os espaços urbanos. Os Estudos de Som contribuem com pesquisas sob perspectivas abrangentes, que vão do estudo da música eletroacústica, arte sonora, música computacional aos estudos de escuta; além da Teoria do Cinema que desde seu início se preocupa com questões relacionadas à conjunção de som e imagem dentro do contexto audiovisual. De maneira geral, é possível perceber atualmente crescente preocupação em abordar mais consistentemente o universo sonoro.

Essa busca, contudo, exige a necessidade de adentrar em campos disciplinares distintos, que algumas vezes possuem termos contrapostos para determinado objeto, outras vezes existem perspectivas e pontos de vista que parecem divergentes. Nesse amplo mapa há hibridizações e complementaridades, que junto às contraposições formam um todo rico e diverso. Sob essa compreensão, a complexidade do assunto determinou a abordagem multidisciplinar da presente pesquisa, que procurou integrar os campos disciplinares de Arquitetura e Urbanismo e Estudos de Som para entender conceitos relacionados à justaposição de entornos sonoros e físicos em espaços públicos, através de interfaces sonoras que promovam escuta coletiva em espaços públicos, que proporcionam diferentes experiências e reflexões nos ouvintes através da escuta. Dessa forma, a presente pesquisa trata principalmente da relação conversacional ${ }^{1}$ entre espaço e som; sem esquecer-se dos modos de escuta.

Considera-se que o som é um elemento relacional, que atua com o espaço e também através dele, como defende LaBelle (2006). O entorno sonoro é formado por um conjunto

\footnotetext{
1 Prefere-se o termo "conversacional" a fim de explicitar a mutualidade e a interdependência entre som e espaço, onde um afeta o outro. A recepção e interpretação do espaço podem-se alterar de acordo com o resultado dessa relação. Trata-se, portanto, de uma interação profunda entre esses dois elementos.
} 
de sons, que é influenciado pelo espaço físico através de fenômenos acústicos, e também influencia a apreensão que se tem de um espaço.

O som, sendo produzido por vibrações físicas que, após todo um processo, o cérebro identifica como som, está presente o tempo todo, é dinâmico e mutável. Se silêncio é a ausência total de sons pode-se inferir que ele só existe na ausência de matéria, na surdez completa e na morte. Sendo produzido por vibrações físicas, os sons e o entorno sonoro, consequentemente refletem nossas próprias ações, movimentos, costumes e modos de vida.

A escuta coletiva trata da ação de determinado entorno sonoro que é comum a mais de um ouvinte, em contraposição à escuta individualizada proporcionada por fones de ouvido. A importância da escuta coletiva é criar algo em comum entre os ouvintes, um assunto compartilhado que transcende o âmbito privado e criando um terreno propício para a constituição de entornos híbridos e a elaboração de loci de comunicação.

O entorno sonoro pode ser transformado e reelaborado através do uso de interfaces sonoras, constituindo entornos híbridos. O uso de interfaces, por sua vez, também concorre para a reconfiguração do espaço. Tanto no próprio entorno sonoro ou na constituição de entornos híbridos por meio do uso de interfaces sonoras, as relações entre som e espaço são intrínsecas, que colabora para a escuta criar, influenciar e formar relações que temos com qualquer entorno (TRUAX, 2001).

A justaposição entre entornos sonoros e físicos promove a constituição de entornos híbridos, que através do adensamento do espaço físico por instâncias virtuais gera um caráter híbrido (TRAMONTANO, 2007). O híbrido promove complementaridades, adensamentos. Através do uso de interfaces, que criam um campo conector entre domínios, contextos ou questões, é possível tornar características do espaço mais notáveis. Esse cruzamento de instâncias físicas e virtuais é um processo que "pressupõe interações entre as partes que compõe o todo, e dessas interações emergem qualidades, às vezes desconhecidas, às vezes inesperadas" (TRAMONTANO; SANTOS, 2013, p. 47).

Neste contexto, Entornos Híbridos: interfaces sonoras em espaços públicos é uma dissertação de mestrado desenvolvida no Programa de Pós-Graduação do Instituto de Arquitetura e Urbanismo, da Universidade de São Paulo, junto ao Núcleo de Estudos de Habitares Interativos, o Nomads.usp. 
Quanto às motivações da pesquisa, elas são originadas tanto do âmbito acadêmico, quanto de vivências pessoais. O som, elemento tão cotidiano, acabava por ser tornar um elemento gerador de reflexão.

Desde antes de sua graduação em Imagem e Som, pela Universidade Federal de São Carlos, a pesquisadora tem sido inquietada por tal elemento. Primeiramente, pelo universo dos sons organizados em forma de música. Depois, como um resultado de sua graduação e de sua atuação profissional, a "domesticação" do som para sua captação em obras audiovisuais e seu forjamento para uni-lo à imagem cinematográfica. E, enfim, a inquietação vinda dos inúmeros anônimos de passagem, do próprio cotidiano, das práticas de escuta e das relações entre som e espaço.

O Nomads.usp busca integrar diferentes campos do conhecimento em suas pesquisas, onde as pesquisas individuais constituem um panorama diverso que abrange variadas áreas. A pesquisa é também fruto desse panorama, que por sua vez contribui com a participação na interlocução com pesquisadores vindos de outras áreas.

De 2010 a 2013, o Nomads.usp desenvolveu o Projeto de Políticas Públicas "Territórios Híbridos: meios digitais, comunidades e ações culturais", também financiado pela FAPESP, Fundação de Amparo à Pesquisa no Estado de São Paulo. Trata-se de um projeto de políticas públicas que teve como temática a construção coletiva de espacialidades híbridas - combinando instâncias físicas e virtuais - em territórios urbanos através de ações culturais. O projeto teve como preocupação a aproximação de olhares diversos de comunidades distintas, explorando a diversidade e a ampliação de olhares de mundo.

Nesse sentido, o projeto Territórios Híbridos visou também aprofundar discussões conceituais em relação ao uso qualificado dessas tecnologias por pessoas e comunidades. Como horizonte maior, foi proposto como resultado final a formulação de políticas públicas capazes de estimular o reconhecimento e valorização de diversidades culturais, socioeconômicas, étnicas e regionais, entre grupos distintos da população residentes em fragmentos urbanos, através de ações de cunho cultural promovidas pelo poder público em cooperação com o terceiro setor, auxiliadas pelo uso de meios digitais. O projeto de políticas públicas Territórios Híbridos foi concebido de forma a criar canais de diálogo entre pesquisas individuais, que contribuem teoricamente com o projeto de políticas públicas e também se alimentam de suas práticas. O projeto contou com parcerias, de nível local a nacional, com instituições públicas, privadas, coletivos e terceiro 
setor, expandindo a abrangência de atuação do projeto. O projeto realizou ações culturais em variados âmbitos de expressão cultural, utilizando-se de meios digitais para promover loci de comunicação entre pessoas de diferentes universos.

A aliança entre teoria e prática dada pelo projeto Territórios Híbridos beneficiou a presente pesquisa através de discussões sobre concepção, métodos e análise com outros pesquisadores, outras vezes incluindo também agentes culturais e parceiros. A pesquisadora participou do projeto Territórios Híbridos tanto no caráter prático quanto teórico, possibilitando não somente reflexões de cunho teórico e metodológico para a pesquisa como também o exercício de atividades práticas, que auxiliam os procedimentos desta pesquisa. O projeto também colaborou para a investigação e maior entendimento de variados assuntos ligados à pesquisa, tais como interface, ocupação de espaços públicos, constituição de entornos híbridos, dentre outros. Dessa forma, participar das ações culturais, de variadas naturezas, e das discussões realizadas pelo Nomads.usp auxiliou o amadurecimento acadêmico.

Apesar do projeto Territórios Híbridos auxiliar o desenvolvimento da presente pesquisa, maiores detalhes sobre o projeto de políticas públicas e de suas compreensões e análises não serão abordados na presente pesquisa, pois não cabe ao escopo da dissertação a discussão de temas como cultura, ações culturais e políticas públicas. Para melhor cobertura desses temas e sobre o projeto, e também reflexões diretamente relacionadas às ações culturais, recomendam-se outras produções acadêmicas de pesquisadores do Nomads.usp e o livro "Territórios Híbridos - ações culturais, espaço público e meios digitais" (2013).

Sob essa perspectiva, o presente estudo procura aliar teoria e prática em sua investigação, através de leituras de intervenções sonoras e, principalmente, através de um experimento que implica em uma intervenção sonora em uma de suas etapas. A relevância do experimento se dá em explorar relações entre som e espaço de maneira prática, aplicando os conceitos teóricos estudados e tecendo correlações entre eles.

Dessa forma, é possível observar na presente dissertação o estudo teórico baseado em fontes de consulta secundárias, formação de um banco de dados com intervenções sonoras interessantes à pesquisa para realizar leituras e, com auxílio desses dois procedimentos, a elaboração e execução de um experimento que, por sua vez, colabora com a aplicação e com a investigação prática dos conceitos estudados. 
O experimento, como um todo, trabalha três elementos: o Conjunto Habitacional Waldomiro Lobbe Sobrinho, popularmente chamado de "o CDHU"²; a Praça do Mercado Municipal de São Carlos; e, por fim, a ferrovia que atravessa essa mesma cidade. $O$ procedimento se deu em etapas, uma primeira etapa que compreende a pesquisa do entorno sonoro dos dois locais, realizada através do método Soundwalk, e uma segunda etapa que se dá através da aplicação de interfaces sonoras na Praça do Mercado Municipal, caracterizando uma intervenção.

A intervenção "Reverberação Urbana" elege o som do trem como um elemento representativo do CDHU e da cidade de São Carlos, e consiste no relocamento do som do trem gravado na CDHU para a Praça do Mercado Municipal, onde o som é reproduzido de forma descontextualizada historicamente, pois a praça nunca foi atravessada pela ferrovia, através de alto-falantes. Assim, através de registros de fotos e vídeos e entrevistas semiestruturadas, procurou-se coletar informações sobre como se deu a escuta das pessoas, sua interpretação sobre o som do trem na praça; além de também, por meio de entrevistas, abordar a dimensão política sobre o CDHU, que possui 928 apartamentos e que tem seu local demarcado pela ferrovia, além de ser considerada bairro periférico. Dessa forma, a intervenção procura trazer essa problemática às pessoas na Praça do Mercado, colocando-as em contato com um contexto distinto através do som. Pode-se perceber nas entrevistas da intervenção reflexões muito diversificadas suscitadas pelo som.

Diante desses aspectos, a intervenção se liga ao contexto histórico e social da cidade de São Carlos, e de tantas outras que têm seu interior atravessado pela linha do trem; como também colabora para o entendimento do som enquanto elemento qualitativo que se relaciona com o espaço.

Nessa perspectiva de proporcionar o aporte prático ao teórico, a estrutura da dissertação se dá em três capítulos e no item de conclusões.

O capítulo I compreende as reflexões teóricas da pesquisa, apresentando questões conceituais que envolvem a constituição de entornos híbridos através de interfaces

\footnotetext{
${ }^{2}$ O Conjunto Habitacional será referenciado dessa maneira nessa dissertação. O Conjunto é referido dessa maneira pelos habitantes por ser o único conjunto habitacional sob o programa da Companhia de Desenvolvimento Habitacional e Urbano na cidade de São Carlos.
} 
sonoras. Para tanto, são discutidas relações conversacionais entre som e espaço, implicando também conceitos como escuta, ruído e uso de interfaces sonoras.

No capítulo II são realizadas análises sobre intervenções sonoras que contribuem para o entendimento dos conceitos teóricos e para a compreensão da atividade prática realizada no curso dessa pesquisa. Para tanto, há, primeiramente, uma reflexão sobre o termo "intervenção", preferido pela pesquisa por se referir a uma alteração sobre um contexto preexistente, pois o espaço nunca é imparcial em relação à intervenção. Em segundo lugar, há reflexão sobre as categorias sobre as quais as intervenções são analisadas.

Procurou-se abordar intervenções de diferentes naturezas, sempre apresentando como características essenciais: uso de interfaces sonoras, com diferentes características entre si; escuta coletiva; e, por fim, sua aplicação em espaços públicos.

Não se pretende realizar um panorama histórico de intervenções sonoras e procura-se não julgá-las de acordo com gêneros, pois se entende que tais trabalhos possuem particularidades e essências abrangentes e que muitas vezes não possuem consenso para serem tipificadas. Contudo, tais leituras auxiliam a compreensão da aplicação dos conceitos teóricos do primeiro capítulo, além de exemplificar potencialidades inscritas no uso de interfaces sonoras em espaços públicos e as relações entre som e espaço que esses trabalhos instauram.

São quatro intervenções abordadas: 21 balançoires, Daily Tous Les Jours, Canadá; Sound Island, Bill Fontana, E.U.A. e França; Tiefdruckgebiet, Heavylistening, Alemanha e Áustria e Voz Alta, Raphael Lozano-Hemmer, México.

O capítulo III expõe criticamente e analisa o experimento e suas etapas. É realizada reflexão sobre os métodos de coleta, a importância das etapas, bem como compreensões acerca do uso de interfaces sonoras na intervenção e reação do público, relacionando-a com conceitos de escuta tratando o som como um elemento representativo e sobre o contexto do CDHU.

As conclusões, por sua vez, demonstram a apreensão obtida através do processo de pesquisa, que engloba de forma mais direta as correlações entre a investigação teórica e o aporte prático. Assim, apresentam considerações críticas sobre o trabalho, avaliando seus resultados e procurando apontar dificuldades, êxitos e aplicações, realizando uma avaliação que assinala caminhos futuros. 



\section{Elaborando entornos híbridos}

A proposta do presente capítulo é formular e discutir ideias e conceitos nos quais a pesquisa se baseia, dentre eles entornos híbridos, interfaces sonoras e espaços públicos. Tais conceitos apresentam-se como bases estruturais da pesquisa, que considera a justaposição de entornos sonoros e físicos através do uso qualificado de interfaces sonoras em espaços públicos, utilizando escuta coletiva. Entende-se que existem variados olhares e perspectivas sobre tais assuntos que não podem ser compreendidos em uma única pesquisa, no entanto esses conceitos são discutidos de acordo com o direcionamento e interesse do presente trabalho. Para tanto, o capítulo se estrutura em torno da reflexão sobre o som como um elemento do espaço e suas relações conversacionais, que podem ser alteradas através do uso de interfaces sonoras, implicando em compreensões sobre escuta, interface e espaço público.

\section{Reverberações}

De maneira resumida, o som é produzido por ondas mecânicas em um meio, e que causam vibrações no tímpano. Essas vibrações são convertidas por um complexo sistema de órgãos auditivos em impulsos elétricos que o cérebro reconhece como sons. Segundo Roederer (1998, p. 17), físicos explicam em termos gerais para interpretar esse processo através da constatação da cadeia de sistemas fonte-meio-receptor. Nesses sistemas envolvidos podem-se categorizar outros processos, relacionando a fonte ao mecanismo de excitação primária, elemento vibrante e ressonador adicional; o meio que transmite o som, a propagação sonora também influenciada pelas instâncias físicas; e o receptor, que, considerando ser o ouvinte, há atuação do tímpano, ouvido interno e sistema nervoso (ROEDERER, 1998, p. 18-20). ${ }^{1}$ Esses termos, apesar de parecerem simplistas em determinada forma, dão um ponto de partida onde há discussões que podem ser estendidas a diversas direções.

\footnotetext{
${ }^{1}$ Esse modelo pode ser complexificado através de interfaces e mediação tecnológica, no entanto será usado como insumo para a discussão a seguir.
} 
O som possui uma relação de causalidade com o movimento. Embora existam muitos tipos e formas de vibração, somente uma pequena gama de frequências pode ser percebida pelo ouvido humano, sendo interpretada pelo cérebro como som. Contudo, além das questões fisiológicas, deve-se levar em consideração que o som é percebido e produzido junto a processos culturais e sociais (STERNE, 2003). Sob esse ponto de vista, o entorno sonoro, sendo formado por sons, não deve ser abordado enquanto um único objeto, e sim como algo resultante de vários processos, que compreendem desde sua relação com o espaço físico até uso de interfaces e também interpretações dadas por processos de escuta.

O som se relaciona diretamente com o movimento e também com o tempo e espaço concreto. O tempo está associado à dinamicidade e efemeridade, de modo que o entorno sonoro é um fenômeno mutável, manifesto em uma relação contínua com o ouvinte.

Em um primeiro momento, o aspecto relacional mais direto entre som e espaço concreto se refere à acústica que pode ser transferido a uma cadeia linear de eventos: criação por variadas fontes sonoras, influência do espaço concreto e interpretação pelo cérebro humano como som. O som reflete detalhes de movimentações físicas de um objeto, 14 colocado como aqui como uma fonte sonora. Contudo, o espaço físico e seus objetos também influenciam as ondas sonoras através de fenômenos físicos. De determinada perspectiva, a onda sonora que chega ao ouvido é também resultado da influência do estado atual do entorno físico (TRUAX, 2001, p. 17).

O aspecto relacional mais direto entre som e espaço pode ser encontrado em suas consequências acústicas, onde o espaço imprime no som suas características. Contudo, sendo a produção sonora derivada de movimentações físicas, o som consequentemente pode expressar ações contidas no espaço físico. O que soa tem uma vibração física, o que denota suas atividades no espaço físico. Essa ideia pode se estender, não se relacionando somente às ações de causa e consequência, como o caminhar e o som do passo, ou o carro e o som do motor, atrito da pista e do deslocamento de ar; mas também podem concorrer para expressar modos de vidas, relações e produções sociais que estão inscritas nessas atividades.

Enquanto que o entorno sonoro tem sua produção relacionada a esses aspectos, os elementos físicos do espaço influenciam as características sonoras, podendo torná-las reverberantes, dispersas, contê-las ou silenciá-las. Em um primeiro contato, o entorno sonoro compreende esses dois aspectos: elementos ativos que influenciam a produção 
sonora, enquanto que os elementos físicos e concretos influenciam as características sonoras.

Henri Lefebvre (2004) indica a possibilidade de se encontrar ritmos nos trabalhos da cidade, vida urbana e movimento. Segundo o autor, a cidade é palco da interação entre espaço, tempo e dispersão de energia: repetição de ações, situações e diferenças; interferências dos processos lineares e cíclicos; início, crescimento, pico, declínio e fim (LEFEBVRE, 2004, p.12). Aqui, processos cíclicos da cidade referem-se à organização social, de intervalos grandes e simples, enquanto processos lineares à rotina diária. Os ritmos variam de acordo com a organização temporal, dia ou mês, e espacial, lugares considerados públicos ou privados, caracterizando um tempo social. Portanto, Lefebvre considera que esse tempo social é feito a partir da existência de relações sociais junto às temporalidades diversas ${ }^{2}$. Assim, além da movimentação e do espaço físico, o som está também relacionado à temporalidade. Padrões sonoros rítmicos e cíclicos podem ser observados tanto na natureza quanto no tempo social e na produção humana, em intervalos temporais longos ou curtos.

Percebe-se relação direta entre som e próprias ações ocorridas no espaço da cidade. Os bairros e comunidades podem possuir características sonoras próprias, que possuem informações e significados sobre seu local, compartilhando experiências sonoras da localidade. Ainda que tais sons não sejam únicos ou particulares de uma localidade, o som de um trem de uma ferrovia que circunda ou transpassa um local possui significados para a comunidade habitante do local, assim como o apito de uma fábrica imprime relações temporais de trabalho e pode conferir um lembrete sobre sua atuação econômica (TRUAX, 2001, p.69).

Dessa maneira, um bairro pode não soar como outro, uma cidade ainda pode possuir elementos sonoros que caracterizam culturas e formas de expressão próprias, ainda que perdidos na intensidade sonora de suas ruas. A audição também é um sentido humano que faz parte na apreensão do espaço da cidade, conforme é sugerido por Southworth ${ }^{3}$ (1969), de que a "experiência visual das cidades é proximamente ligada aos sons que a acompanham" (SOUTHWORTH, 1969, p. 65).

\footnotetext{
${ }^{2}$ Considera-se que determinadas cidades possuem seus ciclos de repetição, no entanto há a ressalva de que tempos de repouso são mais difíceis de serem identificados, quando turnos de trabalho são mais distribuídos durante o dia e a noite, por exemplo.

${ }^{3}$ Southworth (1969) nesse estudo possui seu interesse nas correlações intensas entre som e espaço físico, realizando experimentos em indivíduos privados de audição para a pesquisa, outros de visão e
} 
A questão da temporalidade parece intrínseca à cidade. A cidade é para Lynch (1982) um objeto perceptível que é produto de variados construtores, não havendo um resultado final e sim uma sucessão de fases (Ibid., p.12). Por outro lado, Gordon Cullen (1983) aponta que a percepção ambiental urbana, ou de sua paisagem urbana, compreende a possibilidade de apreensão de conceitos de locais e diversas características que são compostas por uma visão serial, na qual aparecem surpresas e revelações pelo trajeto. Por consequência, a apreensão carrega em si um percurso e temporalidade, que resulta na associação do que se vê e que compõe o todo. O tempo é fundamental e por ele perduram as ações, por consequência a dinamicidade. Permitindo-se uma transposição dessas afirmações, é possível compreender que entornos sonoros implicam uma situação dinâmica semelhante: uma sucessão de fases, que, nesse caso, confere efemeridade e mutabilidade aos entornos sonoros, refletindo ações, movimentos e modos de vida.

Imaginabilidade, termo de Kevin Lynch $^{5}$ (1982), se refere à formação de fortes imagens, dotadas de significados, da cidade pelo observador, "onde os objectos se podem não apenas ver, mas também são apresentados de forma definida e intensa aos nossos sentidos" (LYNCH, 1982, p.20) e é produzida em um processo bilateral entre observador e meio. Assim como na imaginabilidade, a identidade e representação sonora auxiliam essa formação de uma imagem intensa em um ouvinte, que também pode se relacionar com sua vivência ou experiências passadas, não necessariamente sonoras. Os objetos são apresentados aos "nossos sentidos", conforme Lynch (Idem.). Veneza provavelmente não teria a mesma imaginabilidade para alguns observadores se tivesse um entorno sonoro diferente, assim como muitas outras cidades - tanto de maneira positiva quanto negativa.

A imaginabilidade não é necessariamente aliada a algo fixo, limitado, unido, e também não é obrigatoriamente óbvia e clara. Ela está relacionada a atributos da identidade e estrutura da imagem mental (Idem.). Os sons também possuem identidades e significados, tecidos em uma trama de relações, e o entorno sonoro por sua vez pode sugerir e interferir na formação das fortes imagens mentais.

\footnotetext{
indivíduos sem privações. Southworth (1969, p.52) aborda a hipótese de que o som possui uma ligação intensa com a realidade, e que sem som a percepção visual é diferente: o som e a visão interagem entre si. Além disso, Southworth (1969) também identifica em seus experimentos que os indivíduos que não foram privados sonoramente perceberam a cidade mais intensa através do desenvolvimento de relações de contraste e de senso de envolvimento, além de percepção de fluxo e ritmo de eventos.

${ }^{4}$ Tradução nossa. "the visual experience of cities is closely related to the sounds that accompany it".

${ }^{5}$ É possível averiguar colaboração entre Southworth e Lynch em alguns trabalhos publicados. Também é possível identificar estudos posteriores de Southworth que são diretamente influenciados por Kevin Lynch, como por exemplo SOUTHWORTH, M. Shaping the City Image. Journal of Planning Education and Research, vol. 5 , outubro 1985, p. 152-59.
} 
Imagem 1: mapa sonoro de Southworth, identificando sons específicos de cada local de acordo com o trajeto. Fonte: Southworth, 1969.

Michael Southworth, "The Sonic Environment of Cities", Environment and Behavior 1:1(June 1969), pp. 49-70.
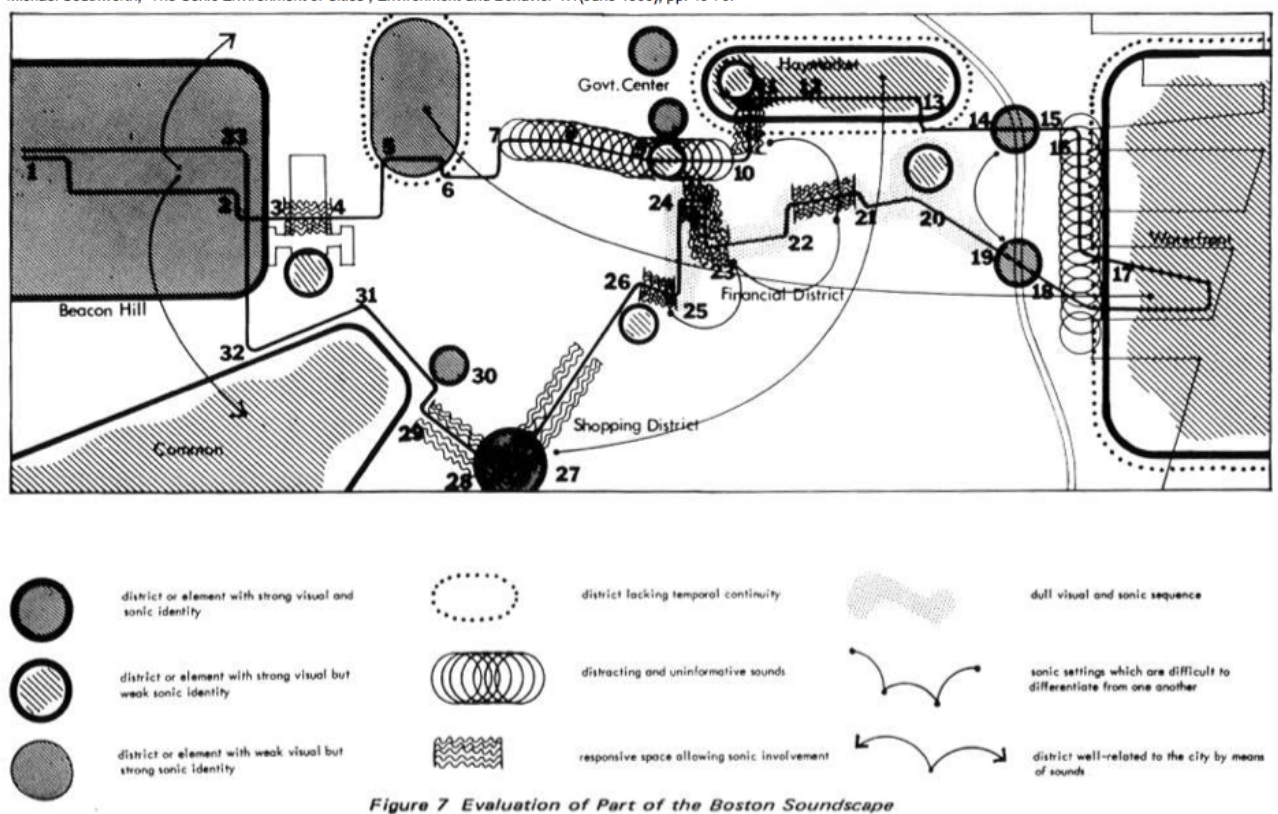

No entanto, há também a perspectiva da descrição de sons característicos de determinado local, na qual o conceito de paisagem sonora de Murray Schafer (2001) se baseia. A paisagem sonora [soundscape] é estudada em variadas pesquisas, empíricas e práticas, com diferentes aproximações

Assim como a paisagem [landscape] refere-se ao que a visão abarca inserida em uma temporalidade, a paisagem sonora se refere a todo evento acústico, seja próximo à fonte sonora ou mediado por interfaces sonoras, que compõe "ambientes reais ou construções abstratas"6, como por exemplo uma composição musical, som de uma televisão, dentre outros. A paisagem sonora [soundscape] pode ser estudada assim como uma paisagem imagética, landscape (SCHAFER, 2001), sendo o resultado de um conjunto de diferentes

\footnotetext{
${ }^{6}$ Schafer (2001, p. 366) realiza essa distinção, no entanto a autora entende esses dois termos como entornos sonoros físicos não mediados, que também incluem a escuta musical em uma sala de concerto, e entornos sonoros mediados por interfaces, que realizam processos de amplificação e que interferem em sua totalidade.
} 
elementos sonoros de variadas naturezas. Barry $\operatorname{Truax}^{7}$ (2001, p.65) defende que o estudo da paisagem sonora também implica a consideração do ouvinte e seu entorno para sua constituição. Originado da terminologia de outras áreas do conhecimento, o conceito de paisagem sonora auxilia a determinação desse ambiente acústico e seus eventos; e o estudo do mesmo o que reflete em criação de uma terminologia particular, aqui brevemente abordada.

Em uma apuração histórica sobre a evolução da paisagem sonora, Murray Schafer (2001) identifica duas categorias principais e antagônicas que se referem a características da paisagem sonora: high fidelity e low fidelity, alta e baixa fidelidade. A paisagem sonora determinada por Schafer como hi-fi, como abreviada pelo próprio autor, é a paisagem sonora em que os sons podem ser ouvidos claramente, atribuindo amplitude à audição, caracterizando-se como um ambiente de baixa intensidade sonora. Para Truax (2001, p.23), o ambiente hi-fi possibilita escuta dos sons com clareza: sons podem ser identificáveis, inclusive detalhes e proporcionando orientações espaciais. Nesse contexto hi-fi, o som pode se propagar em maiores distâncias devido à baixa intensidade de outros sons, que possibilita maior audição do espectro sonoro (composição de frequências de um som) e do conjunto de fenômenos físicos que influem no som. A partir dessa constatação, sendo o som identificável e diretamente relacionado a uma localidade, pode conferir-lhe determinado senso de lugar.

Para Truax (Ibid.) paisagens sonoras hi-fi também possibilitam maiores trocas de informações acústicas entre o ouvinte e seu entorno, pois o ouvinte pode se ouvir mais facilmente. Na paisagem sonora lo-fi, os sons são justapostos entre si devido a sua intensidade, acarretando em perda de diferenciação. A relação "sinal-ruído" é menos favorável, havendo uma "superpopulação de sons" intensos (SCHAFER, 2001, p. 107). Nesse caso, se a amplitude sonora é comprometida e há necessidade de proximidade física entre fonte sonora e ouvinte, especialmente sem a utilização de mediação tecnológica.

Para os autores (TRUAX, 2001; SCHAFER, 2001), os sons são intensos a ponto de se confundirem com seu próprio fundo, criando uma "parede sonora" (SCHAFER, 2001) que compromete a espacialidade e a perspectiva sonora, acarretando em maior isolamento do ouvinte. Se vários elementos produzem sons de alta intensidade, limita-se a perspectiva

\footnotetext{
${ }^{7}$ Barry Truax também foi pesquisador do World Soundscape Project e também possui uma linha de pensamento que se interliga à ecologia acústica com abordagem comunicacional, além de também ser pesquisador de música eletroacústica.
} 
da audição, que se restringe à proximidade entre fonte sonora e ouvinte. Para Augoyard e Torgue (2006, p. 131-7) o âmbito urbano e os espaços arquitetônicos podem possuir condições físicas que favorecem a propagação e deslocalização sonora; efeito que pode também ser enfatizado também com o fundo sonoro da cidade e a multiplicidade de fontes sonoras. Truax (2001) defende também que a paisagem sonora lo-fi fornece informações sonoras redundantes e de pouco valor comunicativo, que acarretam em maior isolamento do ouvinte de seu entorno, ameaçando o sentido de experiência coletiva sonora.

Contudo, é importante considerar que essas categorizações das paisagens sonoras estipuladas por Schafer (2001) não são excludentes: sons característicos de cada paisagem sonora são misturados entre si, não havendo uma paisagem sonora totalmente hi-fi ou lo-fi.

Apesar do conceito de paisagem sonora ser útil para a compreensão do entorno sonoro e ser utilizado em diversos campos disciplinares, é necessária uma reflexão crítica a seu respeito. Ao adotar uma visão ecológica sobre os entornos sonoros, Schafer (2001) os estigmatiza e polariza. Por um lado, ele considera benéfica a paisagem sonora sem intervenção humana. E, por outro lado, critica o seu oposto: a paisagem formada pelos inevitáveis sons da cidade contemporânea, com 'tecnologias ruidosas'. Dessa forma, Schafer opera em uma escala de valor delimitada pelos conceitos de estabilidade e caos, formando posições antagônicas que também podem ser entendidas como uma paisagem sonora "apreciável" (hi-fi) e outra nociva e confusa (lo-fi).

O título A Afinação do Mundo (Schafer, 2001), publicado originalmente em 1977, sugere uma ordenação dessa paisagem sonora. É necessária, possível, ou mesmo desejável, uma "afinação do mundo"? (OBICl, 2008)

Sendo o som resultado de movimentos, ele reflete apenas nossas próprias ações, implicadas em contextos abrangentes e diversos de implicância social, cultural e tecnológica. A redundância dada pelo contexto lo-fi é proveniente dessas mesmas ações. Ainda que os elementos sonoros possam ser redundantes, é possível que eles possuam expressividade e reflitam características, lógicas e dinâmicas de determinado espaço. 


\section{Difusão: Pluralidade de ruídos}

Pode ser considerado a partir da discussão acima exposta que o som produzido na cidade reflete valores e características sociais e culturais que a cidade possui em si. Esse reflexo é importante para o entendimento e compreensão da cidade e, ainda que uma paisagem sonora possa ser considerada lo-fi, ela também pode possuir características próprias ou significados para seus habitantes, positivos ou negativos.

O equilíbrio de uma paisagem sonora natural, hi-fi, pode ser mais proveitoso ao ouvinte do que uma paisagem sonora lo-fi, que pode isolá-lo em si mesmo, contudo, é necessário considerar tanto o valor das atividades que os sons inscrevem quanto o papel desempenhado pelos sons, agradáveis ou não, bem como seu papel reflexivo ou subversivo ${ }^{8}$.

De acordo com Raimbault e Dubois (2005, p. 341):

[...] se a intensidade do ruído do tráfego, aeroporto ou rodovias são responsáveis por stress e outros efeitos na saúde, essas consequências são geralmente menores que a perda auditiva devido à música amplificada. No entanto, o fato é que em um caso o ruído é amplamente considerado como uma indesejável e inevitável poluição e, no outro, como um entretenimento pretendido [...]. Em outras palavras, o julgamento sobre o efeito do ruído sobre a saúde não pode ser feito independente do valor social da atividade (por exemplo, transporte versus prazer) ${ }^{9}$.

A intensidade sonora interfere em nossa escuta, não somente no sentido fisiológico, pois a recepção refere-se também a processos sociais e culturais. Tal fator confere uma característica bilateral do som, entre bem estar e expressividade: como no exemplo da música amplificada no campo da expressividade, e a possibilidade de dano auditivo em decorrência dessa atividade no campo do bem estar. $O$ inevitável e a intenção referentes

\footnotetext{
${ }^{8}$ Ainda que seja considerada a grande importância e validade de estudos relativos à intensidade sonora, a presente pesquisa possui foco em diferentes aspectos.

${ }^{9}$ Tradução nossa. "If the intensity of noise due to traffic, airport or highways is responsible for stress and other health effects, its consequences are generally lower than hearing loss due to amplified music. Nevertheless, the fact is that, in one case, the noise is widely considered as an unwanted and unavoidable pollution and, in the other, as intended entertainment [...] In other words, the judgment concerning the effect of noise on health cannot be made independently of the social value given to the activity under consideration (e.g., necessity of transportation versus pleasure)."
} 
à escuta problematizam tais questões, pois inserem o fator da escolha do ouvinte, derivada também de processos culturais e sociais que, por sua vez, constituem um contexto polifacético quanto às práticas sonoras e de escuta.

No estudo de Southworth (1969), os sons que eram memoráveis aos indivíduos de seu experimento se diferenciavam do resto da sequência ouvida no centro de Boston, pois comunicavam mais sobre o caráter espacial e de atividade. Por outro lado, os indivíduos na pesquisa de Southworth se incomodavam principalmente devido aos sons de carros e caminhões, considerados de alta intensidade, desinformativos e que cobrem uma área abrangente (1969, p. 59-60). Apesar da data do estudo de Southworth, dado no final da década de 1960, é possível estabelecer relações com Raimbault e Dubois (2005) de que esses sons são considerados uma poluição inevitável, sem caráter cultural ou de lazer, e então o incômodo transparece.

O valor significativo de informação e comunicação dado pelo som transforma a recepção, sendo que o som possui um efeito de mediação entre o indivíduo e seu entorno. Seguindo essa constatação, Truax (2001, p. 94) reflete que o ruído é uma fonte de uma mediação negativa entre ouvinte e entorno, dificultando o relacionamento e a comunicação. Assim, nessa perspectiva, tem-se que ruído seria todo aquele som que coloca o relacionamento do ouvinte com seu entorno em detrimento.

Contudo, no âmbito das interfaces sonoras, intervenções, e outras formas de se trabalhar sons de forma qualitativa, a relação som e contexto pode, na verdade, fazer surgir inquietações e estranhamentos, levando ao questionamento do ouvinte e obtendo um produto positivo. Por essas razões, o ruído tem sido trabalhado em variadas vertentes da música ou da arte, como exposto no comentário de Douglas Kahn (1999, p. 21), "com tanto atendimento em relação ao ruído rapidamente torna-se evidente que ruídos são muito significativos para serem ruídos" ${ }^{10}$.

Ruído pode ter significados diversos e também sendo relativo às particularidades de uma comunidade. Assim, possui pluralidade de significados, tanto no campo acadêmico e na elaboração de conceitos, quanto na vida diária e decorrentes interpretações informais. Podem-se referir a deturpações, interferências, sons não musicais ou indesejados.

Jacques Attali (1985, p.26), em uma primeira reflexão, inicia do desenvolvimento da ideia

\footnotetext{
${ }^{10}$ Tradução nossa. "With so much attendant on noise it quickly becomes evident that noises are too significant to be noises."
} 
de que o "ruído não existe em si mesmo, mas somente em relação ao sistema em que está inscrito: emissor, transmissor, receptor"11, seguindo conceitos da teoria da informação e considerando ruído como um sinal indesejável em uma transmissão de mensagem, em um sistema. No entanto, Abraham Moles (1968 apud RUSSO; WARNER,1987) expande os limites do modelo e elabora concepção baseada em percepção cultural: "Um ruído é um som que não queremos ouvir. É um sinal que não queremos receber, que tentamos

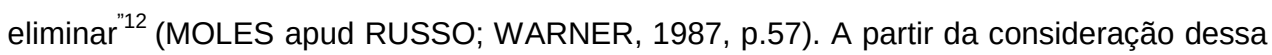
percepção cultural e subjetiva do ruído, o ruído também somente existe em relação a algo ou alguém, pois não é possível sua identificação sem sistema ou contexto. Como escreve Moles (1966 apud COX, 2009),

não há diferença estrutural absoluta entre ruído e sinal. Eles são da mesma natureza. A única diferença que pode ser estabelecida logicamente entre eles é baseada exclusivamente no conceito de intenção da parte do transmissor ${ }^{13}$.

Moles (1966 apud COX, 2009) apresenta a característica relacional da definição entre ruído e sinal, baseada na intenção. No entanto, a recepção também é importante fator. O ruído não existe em si mesmo, e sim somente dentro de um contexto que o inscreve. Se a 22 interpretação do som se dá mediante um contexto, sem contexto não há interpretação (TRUAX, 2001, p. 55).

Attali (1985) assinala que muito antes da abordagem teórica, ruído era experienciado como destruição, desordem e agressão contra as mensagens estruturadas, além de, do ponto de vista fisiológico, ser uma fonte de dor (Ibid.). Dessa maneira, o ruído é considerado desconexão, morte. Através desse pensamento, Attali (1985) desenvolve que a música é a recriação entre sons e a canalização do ruído, retirando sua dimensão trágica: é a organização e a domesticação; enquanto o ruído é destruição e terror, a música é um simulacro de um sacrifício, o homicídio em ritual.

\footnotetext{
${ }^{11}$ Tradução nossa. "Noise, then, does not exist in itself, but only in relation to the system within which it is inscribed: emitter, transmitter, receiver." (ATTALI, 1985, p.26).

${ }^{12}$ Tradução nossa. "A noise is a sound we do not want to hear. It is a signal we do not want to receive, one we try to eliminate".

${ }^{13}$ Tradução nossa. "There is no absolute structural difference between noise and signal. They are of the same nature. The only difference which can be logically established between them is based exclusively on the concept of intent on the part of the transmitter."

${ }^{13}$ Tradução nossa. "there is no absolute structural difference between noise and signal. They are of the same nature. The only difference which can be logically established between them is based exclusively on the concept of intent on the part of the transmitter. A noise is a signal that the sender does not want to transmit."
} 
O ruído é uma das fontes de mutação de códigos estruturados, e uma rede ou sistema que não possuam códigos e regras suficientes para normalizá-lo e repreendê-lo podem ser destruídos por ruídos que os atacam e os transformam (ATTALI, 1985, p. 33). No entanto, como afirma Attali (1985), o ruído na realidade também cria significado, pois a interrupção da mensagem significa uma interdição, censura e também toda a ausência de sentido ou a repetição de uma mensagem liberta a imaginação do ouvinte (ATTALI, 1985, p.30).

A ausência de significado, como dizemos, é absurda; mas também é a possibilidade de quaisquer e de todos significados. Se o excesso de vida é morte, então ruído é vida, e a destruição de velhos códigos na mercadoria [musical] é talvez a condição necessária da real criatividade. Não tendo que dizer nada em uma linguagem específica é a condição necessária para a escravidão, mas também a emergência da subversão cultural. (ATTALI, 1985, p. 122) ${ }^{14}$

Imagem 2: John Neff tocando 4'33", de John Cage.

Fonte: <http://www.artnet.com/magazine/reviews/ velez/velez4-2-7.asp>. Acesso em 04 set. 2013.

Um exemplo da quebra que o ruído proporciona a um sistema, ocasionando ruptura de códigos e estabelecendo outras ordens, é dado pela peça de John Cage 4'33": o músico senta ao piano e marca o tempo citado em três movimentos, sem fazer nenhum som ao piano. O efeito desejado por John Cage nesta peça é que a atenção da audiência seja direcionada aos sons que ela própria produz e que a cercam, incorporando sons considerados não musicais em uma composição (KAHN, 1999, p.165; LABELLE, 2006). Além disso, Cage também critica o código e a rede instaurados no sistema (ATTALI, 1985, p. 136): o que antes

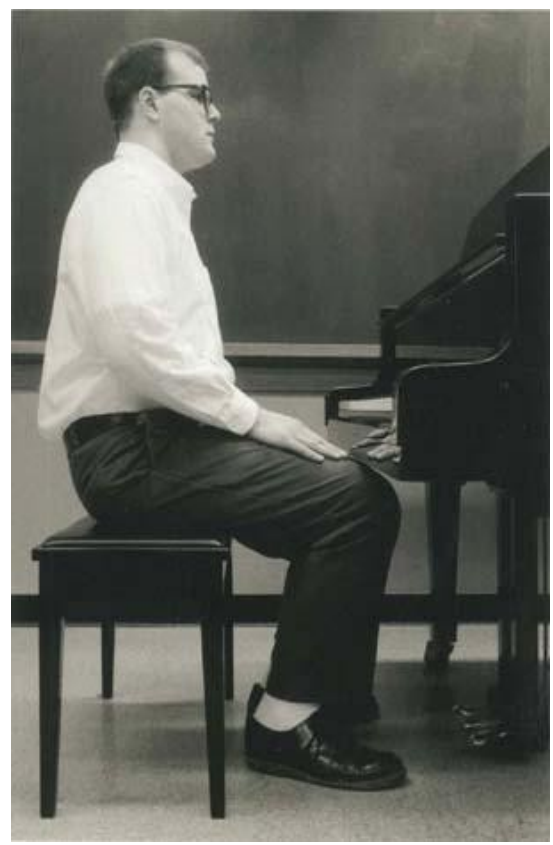

\footnotetext{
${ }^{14}$ Tradução nossa. "The absence of meaning, as we have said, is nonsense; but it is also the possibility of any and all meanings. If an excess of life is death, then noise is life, and the destruction of the old codes in the [musical] commodity is perhaps the necessary condition for real creativity. No longer having to say anything in a specific language is a necessary condition for slavery, but also of the emergence of cultural subversion."
} 
era considerado ruído instaura outra ordem através da atribuição de novos significados. O ruído possui a capacidade de instaurar renovações em códigos que tornaram-se fracos pelo seu uso recorrente em redes em mudança (ATTALI, 1985, p.34). Essa reflexão também sustenta a ideia que os sons incorporam diversidade de códigos culturais, gerando grande variedade também através de seus significados inscritos que, por sua vez, são múltiplos e inconstantes (KAHN, 1999, p. 162).

Se a composição e o design dão significados aos ruídos, instaurando códigos e estabelecendo novas ordens, o ruído possui também o caráter subversivo de poder ser matéria-prima na criação de sentidos. Para Attali (1985) a composição muda as regras em direção à criação coletiva, criando também canais de comunicação: "o aleatório, então, reencontra ordem. Qualquer ruído, quando duas pessoas decidem investir seu imaginário e desejo nele, torna-se uma relação potencial, futura ordem" ${ }^{15}$ (ATTALI, 1985, p. 143).

Mas o ruído realmente existe, e tentar defini-lo de um modo unificador em toda gama de contextos só irá convidar o ruído sobre si mesmo. Suprimindo o ruído só contribui para sua tenacidade e diminui a investigação de meios complexos através dos quais o próprio ruído é suprimido; e ao comemorar o ruído torna-o facilmente em uma tática de suprimir qualquer outra coisa. ${ }^{16}$ (KAHN, 1999, p. 21).

Tentar unificar o conceito de ruído pode acarretar em definições precipitadas - insere mais ruído e desentendimento. Por ser multifacetado, o ruído apresenta-se como uma categoria ambígua que é definida socialmente e em constante renegociação, pois depende de um sistema e também de contextos sociais e culturais. A distinção entre sinal e ruído é muito mais relativa do que absoluta. Em relação ao campo auditivo, assim como objetos preenchem o espaço visual, ruídos preenchem a audição quando combinados entre si, não sendo somente um som entre tantos outros: ruído é o conjunto de forças sonoras capazes que estabelecer relações diferenciais, podendo ultrapassar sua condição e tornar-se a base e a condição para a existência do som significativo (COX, 2009).

\footnotetext{
${ }^{15}$ Tradução nossa. "The aleatory then rejoins order. Any noise, when two people decide to invest their imaginary and their desire in it, becomes a potential relationship, future order."

${ }^{16}$ Tradução nossa. "But noise does indeed exist, and trying to define it in a unifying manner across the range of contexts will only invite noise on itself. Suppressing noise only contributes to its tenacity and detracts from investigating complex means through which noise itself is surpresed, while celebrating noise easily becomes a tatic of supressing something else."
} 


\section{Como soa?}

A audição é um elemento claramente importante quando tratamos do tema da pesquisa, e principalmente considerando o entorno sonoro como um dos elementos através dos participam da apreensão do espaço. Também, através da consideração da importância da escuta, inserem-se também pessoas no processo relacional entre som e espaço.

Ouvir, escutar; audição, escuta: esses termos representam, como poderá ser verificado, o nível de sensibilização do ouvinte ou de importância dada ao entorno sonoro. Apesar de serem palavras semelhantes, podem ter sentidos e implicações diversas. A importância, no entanto, reside mais nas diferenciações entre um termo e outro na presente pesquisa.

Roland Barthes (apud LABELLE, 2006, p. 158; BARTHES, 1985) realiza distinções entre escutar e ouvir ${ }^{17}$ : são modos separados de fornecer atenção ao som em diferentes níveis de consciência, atos passivos e ativos. Barthes (1985) estabelece a relação entre o fenômeno fisiológico e mecânico de "ouvir", realizado de forma passiva, e o ato psicológico de "escutar", onde para o ser humano a apropriação do espaço é também uma questão sonora.

Brandon LaBelle (2006, p. 158) expõe que o ato de ouvir é decisivo, um processo de externalização e interiorização que incorpora entornos e sua audibilidade. Tal afirmação de LaBelle sugere que o ato de escutar, enquanto ato psicológico tal como argumentado por Barthes, propõe condições relacionais entre escuta, entornos sonoros e o espaço.

Em seus estudos sobre as formas e modos de escuta, Pierre Schaeffer ${ }^{18}$ (1988), também identifica um modo que é passivo, podendo tomar variadas formas que não aprofundam seu processo. Conforme o autor, ouvir [ouïr] é um ato contínuo, dado que a audição humana nunca cessa, nem o entorno sonoro. Ouvir, para Schaeffer (1988, p.62-3), é perceber com o ouvido, ou seja, ouve-se o que é dado pela percepção, sem

\footnotetext{
17 Hear e Listen.

${ }^{18}$ Compreende-se que há complexidade nas teorias de escuta de Schaeffer e de Barthes, contudo não é interesse da pesquisa analisá-las em seus pormenores por ser um estudo extenso que se correlaciona com diversas questões. Portanto, resolve-se ater à diferenciação entre ouvir e escutar.
} 
necessariamente haver intenção. A consciência do que se ouve é um processo acontece através da reflexão ou memória.

Adapto-me instintivamente a ele [o som], aumentando a voz quando seu nível se eleva, sem sequer me dar conta. No entanto, conhece-se o exemplo de gente que, morando próximo de uma estação, repara quando o trem não passa em seu horário (SCHAEFFER, 1980, p. 63) ${ }^{19}$.

Apesar dessa afirmação de Schaeffer parecer exagerada ou radical, a adaptação do ouvinte em relação ao seu entorno sonoro se dá, talvez, como uma forma de entorpecimento da escuta devido a ocasiões como falta ou excesso de variabilidade como, por exemplo, quando se percebe conscientemente determinado som quando este cessa, ou quando causa um estranhamento devido à sua falta de contexto. Sem necessariamente se pautar em uma intenção, a escuta cotidiana pode se adaptar a um entorno sonoro comum, reduzindo sua sensibilidade a algumas características sonoras não tão perceptíveis.

Contudo, os dois estudos, apontam para duas categorias principais: audição atenta, ativa e reflexiva; e a audição que não é internalizada conscientemente ou intencionalmente. Assim, difere-se o sentido fisiológico da escuta de seu sentido de compreensão, de perceber determinadas características ou estar atento ao som de forma qualitativa. No entanto concorda-se com Salomé Voegelin (2010) que não é porque não se escuta com atenção que o som não forma a realidade, fazendo parte de um contexto.

O engajamento auditivo, contudo, quando não está a serviço de simplesmente decorar o objeto visual pragmático, exerce um engajamento diferente. Deixada no escuro, eu preciso explorar o que eu ouço. A escuta descobre e gera o que é ouvido (VOEGELIN, 2010, p.4). ${ }^{20}$

Voegelin (2010) discute que é desse processo de se ter um engajamento mais profundo que gera um descobrimento através da escuta, que dirige ao conhecimento.

A escuta do som forma parte da realidade, contudo é através do processo de engajamento da escuta que se gera um descobrimento através da audição, que direciona ao

\footnotetext{
${ }^{19}$ Tradução nossa. "Me adapto instintivamente a él, elevando la voz cuando su nivel se eleva, sin si quiera darme cuenta. Sin embargo, se conoce el ejemplo de gente que, vivendo cerca de uma estación, se despierta cuando el tren no passa a su hora"

20 Tradução nossa. "The auditory engagement however, when it is not in the service of simply furnishing the pragmatic visual object, pursues a different engagement. Left in the dark, I need to explore what I hear. Listening discovers and generates the heard."
} 
conhecimento. É um processo individual e contingente, como a própria autora afirma (Ibid.), e também que considera outras experiências anteriores do ouvinte, não unicamente sonoras. Forma-se uma cadeia de relações durante o processo da escuta mais engajada, da qual podem se gerar reflexões diversas.

Outros autores também lidam com características diferentes de escuta cotidiana, mediada ou não por meios digitais e eletrônicos, atribuindo categorias. Katharine Norman (1996, p.5) chama de escuta referencial ${ }^{21}$ quando primeiramente ouvimos sons e tentamos relacioná-los a eventos e objetos, procurando correspondência visual da escuta. Trata-se de uma forma de suplementar a audição e, segundo a autora, tal correspondência com a visão pode se referir a uma tentativa de trazer a experiência sonora à realidade temporal, definindo o que acontece em nossa presença. Na escuta referencial, atenção torna-se sinônimo de visão, onde cria-se uma percepção interna do espaço procurando correspondências de causa e efeito. Além disso, "a escuta referencial conecta sons a objetos, a medições de tempo e lugar e a 'símbolos' aprendidos"² (NORMAN, 1996, p.11).

A mediação tecnológica, no entanto, coloca em detrimento a escuta referencial principalmente no aspecto direto de causa e efeito. Através da reprodução e outros processos, o som produzido é mais ligado quanto aos "símbolos' aprendidos", como Norman (1996) estabelece, do que à correspondência direta entre visão e audição, pois as características físicas dos objetos não correspondem necessariamente ao seu som produzido.

Tais aproximações entre visão e audição, e suas correlações diretas que a escuta pode implicar, são parcialmente desatreladas no caso da escuta acusmática, a escuta do que não se vê. O termo "acusmático" refere-se à filosofia grega. Pitágoras ensinava seus alunos falando atrás de uma cortina, a fim de proporcionar maior entendimento e concentração das lições através da privação do sentido da visão (SCHAEFFER, 1988). Todavia, a escuta acusmática determinada por Schaeffer (1988) é pautada principalmente pela cadeia de reprodução: o que antes era dado por uma cortina hoje se dá pelas formas de reprodução e transformação sonora (SCHAEFFER, 1988, p.56). Historicamente, a música acusmática é diretamente relacionada à composição em estúdio, pela

\footnotetext{
${ }^{21}$ Tradução nossa: Referential Listening.

${ }^{22}$ Tradução nossa: "referential listening connects sounds to objects, to measurements of time and place and learnt 'symbols'".
} 
manipulação sonora através de equipamentos, com ausência do intérprete e de seus gestos.

Nesse contexto, pode-se considerar a escuta acusmática cada vez mais presente no cotidiano, principalmente as que correspondem aos formatos fonográficos musicais. Considerando a proximidade física entre ouvinte e fonte sonora, sem mediação tecnológica, como escuta direta, esta escuta corresponde ao entorno sonoro atrelado à visão, ou seja, o entorno sonoro acústico, sem a inserção de tecnologias sonoras. Usualmente os sons são percebidos e diretamente relacionados à sua fonte sonora, atribuindo causas ao som. A escuta acusmática, porém, proporciona um menor comprometimento do som à sua fonte sonora, mas não de forma totalizante.

Norman (1996) também faz a distinção entre a escuta referencial da reflexiva, relacionada ao significado conceitual dos sons, tratando-se de uma experiência mais qualitativa do que quantitativa, porém que não é alienada da memória e da imaginação. No entanto, a imaginação é responsável por prover outras interpretações do som, com menos percepções de lugar comum (NORMAN, 1996, p. 14), através de associações que instauram perspectivas mais particulares e pessoais, ocasionando em uma pluralidade de interpretações. Assim, a autora discorre sobre a escuta contextual, que se refere à avaliação do material sonoro pelo ouvinte, de acordo com seu contexto:

Isso implica que ambas atividades de escuta, referencial e reflexiva, na verdade ocorre ao longo de um campo pervasivo, no qual material e contexto são interrelacionados e avaliados. É nesse campo, um acúmulo de conhecimento individualmente experienciados, que se estende sob nossas novas experiências para influenciar e condicionar nossa direção perceptual. Antes de qualquer aquisição de informação referencial específica, nós relacionamos nossas experiências atuais ao nosso histórico de experiências, ao contexto de nossas vidas ${ }^{23}$ (NORMAN, 1996, p.18).

Dessa forma, a escuta contextual relaciona o material sonoro, em um âmbito referencial e

${ }^{23}$ Tradução nossa: "This implies that both referential and reflective listening activity in fact takes place over a pervasive ground, through which material and context are interrelated and evaluated. It is this ground, an amassing of individually experienced knowledge, that extends beneath all our new experiences to influence and constrain our perceptual direction. Prior to any acquisition of specific referential information, we relate our current experience to our experiential history, to the context of our lives." 
reflexivo, ao contexto da história individual do ouvinte, influenciando a imaginação sobre o som, bem como os significados fornecidos por ele. Tal constatação também imprime o sentido relacional entre cultura e som, estabelecendo divergências e heterogeneidades em sua recepção.

Michel Chion (1994), em estudo amplamente referenciado pela teoria do cinema, define três modos de escuta: causal, semântica e reduzida, que não são excludentes entre si. A escuta causal é apontada como a mais comum, quando consiste em ouvir determinado som a fim de coletar informações com sua fonte (CHION, 1994, p. 24-26). Ao mesmo tempo em que essa escuta possui relação de causa e efeito, de maneira similiar à escuta referencial, esse modo não necessita da visão da fonte sonora. Porém, reconhece-se que há maior dificuldade na identificação específica da fonte do som quando não é diretamente vista. No exemplo de Chion, há maior dificuldade em determinar qual é o latido particular de um cachorro em meio a uma matilha que late. A escuta causal para o autor também se refere a uma imaginabilidade, como imaginar aspectos físicos de um interlocutor de rádio, bem como determinar uma natureza geral da procedência de um som: uma máquina, um animal. A escuta semântica refere-se ao entendimento de códigos e linguagens para a interpretação de uma mensagem, exemplificados pelo autor (Ibid., p. 28) como a língua falada ou o código morse. O autor não desenvolve com muita profundidade esse modo de escuta, no entanto toma-se como pressuposto que é inclusa a linguagem que é interpretada e entendida, ou que é de conhecimento do ouvinte que possui um significado linguístico. Pode-se não entender o código morse, ou a língua russa, no entanto é de reconhecimento que aqueles sons são possuidores de um conteúdo semântico.

Por fim, Chion (1994) recorre à Schaeffer (1988) para refletir sobre a escuta reduzida. A escuta reduzida compreende a escuta do som em si, independentemente de sua causa ou significado (SCHAEFFER, 1988, p. 165; CHION, 1994, p. 29). A escuta reduzida refere-se ao objeto sonoro, que não se trata do sinal físico do áudio ou de sua transdução, pois não pode ser quantificado. Grosso modo, a fim de estruturar o pensamento à presente pesquisa, o objeto sonoro pode ser definido através dos termos de Chion (1994, p. 29), "som [...] como ele mesmo, como um objeto a ser observado ao invés de ser um veículo de outra coisa" ${ }^{24}$. Para Schaeffer (1988) a percepção sonora não é um fenômeno puramente individual, portanto a escuta reduzida está no âmbito da objetividade: o som

\footnotetext{
${ }^{24}$ Tradução nossa: "the sound [...] as itself the object to be observed instead of as a vehicle for something else".
} 
deve ser fixado e ouvido variadas vezes, pois a escuta reduzida não é alcançada em uma única vez. Trata-se de "uma redução ainda mais rigorosa que a redução acusmática" onde "é o próprio som que me interessa, aquele que eu identifico" ${ }^{25}$ (SCHAEFFER, 1988, p. 163), conotando portanto a intencionalidade de ouvir às qualidades inerentes ao som.

A ideia de escuta reduzida enfatiza a audição preocupada em entender as características sonoras, diferenças entre sons, na preocupação da forma na qual determinado som se apresenta, sendo assim um exercício útil de escuta, pois a atenção é voltada às características sonoras. A escuta reduzida, no entanto, não é imune ao criticismo. Defende-se na presente pesquisa que a objetividade pura na escuta não existe. Ainda que a identificação sonora ou associações que os ouvintes tragam sobre o som possam ser similares, essa identificação geralmente acontece quando o som provém de uma fonte reconhecível ou o grupo possui perspectivas culturais em comum. As características relacionais do som são difíceis de serem desfeitas no âmbito da interrelação entre som, espaço e contexto. O som, de maneira geral, possui heterogeneidade, pois não é possível ignorar a carga cultural e social do indivíduo ou grupo, bem como seu contexto.

Dentro desse breve panorama sobre escuta, é possível identificação de duas perspectivas quanto aos modos de escuta: uma em relação à internalização do som pelo ouvinte e outra direcionada ao objeto de escuta. A escuta ativa e reflexiva, que vai além de seu contexto fisiológico, promove também apropriação do entorno soro e, consequentemente, do espaço. Nota-se que não somente a visão e a audição interferem nas formas de apropriação, devido à multissensorialidade. Porém, o som determina sua abrangência quanto ao espaço de maneira semelhante à visão, no sentido de que possui uma abrangência mais ampla que o tato, por exemplo.

A visão isola, enquanto o som incorpora; a visão é direcional, o som é omnidirecional. O senso da visão implica exterioridade, mas a audição cria uma experiência de interioridade. Eu observo um objeto, mas o som me aborda; o olho alcança, mas o ouvido recebe (PALLASMAA, 2005, p. 46).

O som participa de outros processos relacionais com o espaço além dos acústicos, que também influenciam na sua percepção. O entorno sonoro é dinâmico, sempre mutável, resultante de variados elementos que agem, que permeia o ouvinte todo tempo. Sob esse ponto de vista, o entorno sonoro não deve ser abordado enquanto um único objeto, e sim

25 Tradução nossa: "uma reducción más rigurosa aún que la reducción acusmática"; "es elpropio sonido lo que me interessa, aquello que yo identifico". 
como resultante de vários elementos, pois o som é percebido e produzido de forma interdependente a processos culturais e sociais. Conforme Barry Truax (2001, p.12) discute, a significância comunicacional do som só pode ser julgada dentro de seu contexto completo, no sentido social e cultural mais amplo. Baseando-se nos três elementos colocados por Truax (2001), representando um processo sob o qual pessoas, sons e entorno se inter-relacionam, pode-se concluir que, nesse conjunto, os sons possuem papel ativo de influência entre pessoas e seu entorno.

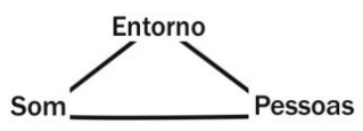

Considera-se o entorno sonoro como um elemento relacional, atuando em conjunto e também através do espaço. Como afirma LaBelle (2006), som possui características relacionais, principalmente com espaço, podendo operar através de modos de espacialidades. Assim, o entorno sonoro refere-se a um dos aspectos através dos quais se têm a percepção do espaço, e é resultado da junção de variados elementos sonoros, mediados tecnologicamente ou não. A percepção dada pelo entorno sonoro pode se justapor a outras características do espaço, sendo uma instância que pode também auxiliar em suas configurações. Sons podem se relacionar com espaço, ao mesmo tempo reconfigurando-o ou dissolvendo-o.

Sob determinada perspectiva, o entorno sonoro é ubíquo: sons nunca cessam, não existe a possibilidade de privar o ouvido da audição assim como fechamos os olhos para impedir a visão. Como argumenta John Cage (1961, p.22-23), silêncio é formalmente considerado a pausa entre dois sons, dentro de uma perspectiva musical tradicional na qual o silêncio torna-se sons que não provém dos instrumentos. Esses sons, no entanto, estão presentes em todos os locais e ocasiões. Como exemplificação, há o conhecido relato pessoal de Cage (1961, p.8, p. 13, p.23): o compositor entrou em uma câmara anecoica, sala tão silenciosa o quanto a tecnologia permite, e percebeu duas frequências: uma alta que se refere à operação do sistema nervoso; e uma grave, dada pela circulação sanguínea. Assim, há a consideração de que o silêncio, se considerado como ausência total de sons, talvez exista somente na debilidade fisiológica da surdez.

Segundo Truax (2001, p. 13) a experiência acústica, a experiência dada através da 
audição, "cria, influencia e forma as relações usuais que temos com qualquer entorno" 26 . Dessa forma, o ouvinte não é mais o receptor de um sistema de comunicação linear, e sim faz parte de uma cadeia que envolve também o entorno sonoro e espaço, que constantemente se influenciam entre si. A partir dessa perspectiva, considera-se que a relação dos entornos sonoros pode ser discutida além de seus aspectos acústicos, principalmente pelas complexificações das relações e produções espaciais trazidas pelo uso de interfaces sonoras. Direcionando a atenção ao uso de meios digitais e eletrônicos, veem-se possibilidades de ampliação desse horizonte acústico, além do evidenciamento de características do espaço que podem não ser tão perceptíveis sem o uso dessas técnicas.

\section{Ressonâncias: considerações sobre espaço}

A partir da consideração do som como um elemento do espaço, que age de maneira conversacional, é de interesse a consideração do espaço não como um invólucro delimitador ou contêiner de objetos físicos, e sim como possuidor de caráter reflexivo e heterogêneo, formado também por dinâmicas sociais e culturais e além de instâncias físicas. No entanto, a diversidade de perspectivas conceituais em relação ao espaço, como também ao espaço público, não são possíveis de serem abordadas em uma única pesquisa. Dessa maneira, para foco da presente pesquisa, são apresentadas e discutidas ideias que contribuem para a consideração do caráter conversacional entre som e espaço, bem como discutindo espaços públicos que são de interesse da pesquisa.

Lynch (1980, p.11) inicia seu livro "A imagem da cidade" argumentando que os elementos móveis, as pessoas e suas atividades, são tão importantes quanto as partes físicas da cidade. O autor aborda que não somente de características relativas ao espaço físico são relevantes para a consideração de seu objeto. Prosseguindo e ampliando esse argumento, o espaço pode ser considerado não somente seus objetos físicos, como também todas as ações que ocorrem nele e que o determinam. Há assim a consideração de que o espaço é formado tanto por instâncias físicas quanto pelas dinâmicas que lhe são próprias. Não somente formado pela sua matéria inerte, como também elementos que

\footnotetext{
${ }^{26}$ Tradução nossa. "creates, influences, and shapes the habitual relationships we have with any environment".
} 
Ihe dão vida.

Configurações físicas possibilitam ou delimitam determinadas ações no espaço, no entanto dois espaços físicos com as mesmas características podem ter usos completamente diferentes. Dessa maneira, reforça-se a ideia de Milton Santos (2001) sobre o espaço sendo formado por um conjunto de fixos e fluxos, ou seja, da interação de instâncias físicas, movimentos e dinâmicas inscritas. Os elementos fixos permitem ações, fluxos recriam condições ambientais e sociais, sendo resultado direto ou indireto das ações que permeiam os fixos; assim realizado um processo de interdependência, onde um altera o outro.

Ações e objetos interagem de maneira inseparável, levando à dinamicidade de situações e processos (SANTOS, 2001, p.61). Como Milton Santos (2001, p. 63) descreve:

Sistemas de objetos e sistemas de ações interagem. De um lado, os sistemas de objetos condicionam a forma como se dão as ações e, de outro lado, o sistema de ações leva à criação de objetos novos ou se realiza sobre objetos preexistentes. É assim que o espaço encontra sua dinâmica e se transforma.

Tem-se a partir dessa perspectiva de que o espaço, portanto, não está somente limitado ao seu caráter determinado por instâncias físicas, ainda que tais instâncias possam possuir diversas categorias. As ações são próprias das pessoas e são resultantes de necessidades naturais ou criadas de diversos âmbitos: materiais, imateriais, econômicas, sociais, culturais, morais, afetivos (SANTOS, 2001, p.82).

A variedade de atividades humanas depende de contextos, desde complexos de segregações, conflitos sociais e históricos, até condições do espaço concreto. Na visão do antropólogo Edward Hall o uso do espaço é uma elaboração especializada da cultura (HALL, 1977, p. 13): a cultura é responsável pelo uso e estruturação do espaço, sendo que o sentido humano do espaço é resultado de variadas sínteses sensoriais. Nessa visão, portanto, o espaço é dado como heterogêneo e apreendido de acordo com filtros culturais, em que, às vezes, várias características passam desapercebidas. O espaço varia culturalmente, de indivíduo para indivíduo, e comporta-se como dado fundamental para sensações, atividades e instituições.

É conhecida a abordagem política do espaço público, representada por escritos de autores como Hannah Arendt (1958) e Jürgen Habermas (1962), de que o espaço público é associado pelo encontro de cidadãos para produzir discussões sobre assuntos de 
preocupação pública de forma livre e aberta. A grosso modo, Arendt (1958) trabalha sobre os conceitos de vida pública e vida privada para constituir seu entendimento sobre espaço público, e é em público onde o indivíduo exerce suas atividades públicas, e o caráter público perde-se quando as pessoas não vêem motivos para se agregarem para exercer sua liberdade e influenciar decisões políticas. Por outro lado, Habermas (1962) determina 'público' como acontecimentos acessíveis a quaisquer pessoas, onde uma de suas marcas é a luta de classes, apoiando-se na teoria marxista. Como é possível verificar, tal discussão é muito ampla e difícil de ser abarcada em apenas uma pesquisa.

Contudo, para proveito da presente pesquisa, prevalece-se o entendimento do espaço público como um locus de cultura compartilhada, de interesse público, onde envolve diversidade, sociabilidade e o convívio de olhares e perspectivas diferentes. Para isso, sustenta-se que se deve enxergar o "público" como uma característica fundamental desses espaços, como uma qualidade que se refere a um potencial comunicativo, de sociabilidades e atividades em comum de grupos de pessoas ou comunidades, exercendo funções de convívio social, de maneira que comporte também diversidade de pessoas.

Estes espaços conferem diversas características particulares em seu uso devido às 34 dinâmicas sociais e culturais, e, portanto, não é isento de ambiguidades e dicotomias. Esses aspectos polares são provenientes tanto de seus aspectos físicos de acessibilidade quanto formas de controle, vigilância e presença de empresas privadas através da publicidade.

Lilia Voronkova e Oleg Pachenkov (2011), considerando praças como espaços públicos urbanos tradicionais na Europa, discorrem que esses espaços possuem uma natureza ambígua sobre seu caráter público em diferentes contextos de cada cidade. Os autores (2011) indagam sobre diversas características sobre esses espaços em relação ao acesso e abertura: segregação social; domínio de determinados grupos sobre o espaço; presença de empresas privadas e de sua decorrente publicidade; vigilância, seja remota ou presencial, por câmeras ou autoridades. Uma praça pode ser acessível quanto às suas dimensões físicas, porém podem ter limites implícitos através de vigilância e autoridades que determinam quem pode utilizá-los, removendo os indivíduos que não são desejados (VORONKOVA; PACHENKOV, 2011); ou até mesmo o estabelecimento de grupos sociais que intimidam ou não permitem a ocupação do espaço por outros grupos de maneira simbólica.

Um exemplo disso em relação ao uso sonoro pode ser o Sterne $(2005$, p.48) aponta como 
"música de dissuasão não-agressiva". Trata-se do uso de música, por vezes discreto, que estimula segregações e prevalência de grupos. Há exemplo de lojas que preferem fazer uma lista de músicas pensada para atrair consumidores com perfis desejados e que, por consequência, ajuda a delimitar a presença de pessoas que não compartilham daquele determinado gosto musical. Nesse exemplo, o entorno sonoro atua como uma estratégia para 'proteger' espaços, criando um "dentro e um fora” (STERNE, 2005, p.48).

No entanto, para além do quesito de sociabilidades, interação e comunicação entre pessoas, o "público", fundamental característica do espaço aqui discutido, refere-se também a outros aspectos, como aborda Manuel Castells (2008): "a esfera pública não é somente a mídia ou os sítios sócio-espaciais de interação pública. É o repositório cultural/informacional de ideias e projetos que alimentam o debate público" ${ }^{27}$, onde a essência da comunicação se dá através de um significado cultural em comum. O público trata do domínio de interesses e valores compartilhados (DEWEY, 1954 apud CASTELLS, 2008). Trata-se de uma organização que transcende o âmbito do privado.

Sob a luz de que a esfera pública é também o lugar onde ideias e projetos culturais e informacionais alimentam o debate público, além de também ser local e meios sócioespaciais de interação pública, é importante também considerar o que Jane Jacobs (2000, p. 119$)^{28}$ defende: inserção espontânea da vida cultural faz parte da missão histórica das cidades. Assim, os espaços devem ser capazes de possibilitar a inserção da vida cultural, bem como interação pública.

Jane Jacobs (2001) discorre que a vitalidade e animação dos espaços públicos são provenientes da diversidade, onde tipos arquitetônicos e pessoas interagem. Para a autora, o importante não é somente a colocação e inserção, quase que artificial, de um espaço público. O espaço público precisa dialogar com os arredores bem como ter a capacidade de absorvê-los, também suas características socioculturais, como a autora explica com relação aos parques:

os parques urbanos não são abstrações ou repositórios automáticos de virtudes ou avanços, assim como as calçadas não são abstrações. Eles nada significam se forem divorciados de seus usos reais, concretos e, portanto, nada significariam se divorciados das influências concretas boas ou más - dos bairros e usos que os afetam. [...] Não basta só ter

\footnotetext{
27 Tradução nossa. "The public sphere is not just the media or the sociospatial sites of public interaction. It is the cultural/informational repository of the ideas and projects that feed public debate."

28 "Morte e vida de grandes cidades", de Jane Jacobs, foi publicado pela primeira vez em 1961.
} 
parques, eles são afetados pelos seus arredores. Eles têm seus usos divididos. Atividades culturais fomentam o uso dos parques, desde que consonantes com sua vizinhança. É um problema ter parques vazios, pela sensação de segurança. O parque precisa ser sustentado pelo uso da própria vizinhança. O parque deve agregar diversidade de usos. (JACOBS, 2001, p.121)

Não somente a existência de um equipamento e de um espaço físico, construído com a intenção de ser uma referência e um ponto de encontro, torna-o um espaço público. O público provém de atividades que as pessoas exercem, da absorção e apropriação do espaço por elas. Esse espaço pode se referir tanto a um espaço físico quanto a loci de comunicação que não são palpáveis, e que só existem quanto utilizados, como por exemplo tecnologias da informação e comunicação que podem propiciar um terreno para a discussão e debate de assuntos compartilhados, públicos. Uso de interfaces pode fomentar essas discussões e ideias, conferindo um locus de comunicação, onde o público se dá.

As relações instauradas em espaços físicos também são transformadas através do uso de tecnologias da informação e comunicação. Em um ponto de vista tecnológico, tais tecnologias, incluindo meios digitais e eletrônicos, possuem alto caráter de obsolescência, no entanto sua construção social e histórica implica em mudanças de modos de vida e também em transformações da experiência sobre o espaço (FIRMINO; DUARTE; ULTRAMARI, 2011). Essas transformações se dão também com o uso de interfaces sonoras, do relacionamento entre som, espaço e ouvinte, que pode ser observado principalmente com a presença de tecnologias de uso diário como celular ou tocador de mp3, além de outras tecnologias e seu contexto histórico (BULL, 2000; STERNE, 2003; IAZZETTA 2012; OBICI, 2008).

Instâncias virtuais também estão entrelaçadas ao espaço físico, cuja relação se pauta pela "incorporação crescente e imperceptível de tecnologias da informação e comunicação (TICS) em sistemas e estruturas da vida urbana", que catalisam transformações espaciais e vivenciais nas cidades (FIRMINO; DUARTE, 2008).

Foth, Choi e Satchell (2011) entendem a cidade como uma ecologia que consiste em camadas tecnológicas, sociais e arquitetônicas, com interações que promovem entornos que incluem tecnologia, instâncias físicas e materiais e pessoas. Através desse processo são alterados comportamentos, percepções e expectativas no espaço urbano (Idem.). Ecologia, pois tais camadas possuem interações entre si e não se encontram separadas 
definidamente. Isso também reflete a dificuldade em separar o imbricado formado por instâncias virtuais e concretas.

Como afirma Dana Cuff (2003) há incorporação espacial dessas instâncias virtuais, o que a autora denomina como cyburg. Aborda-se a ideia de que tecnologias atuais podem estar em todos os lugares e em lugar nenhum, operando também espacialmente. Os já antes tênues limites entre público e privado tornam-se ainda mais imperceptíveis, por se referirem não somente a espaços físicos, como também espaços metafóricos como discurso público, normas sociais, interação e pertencimento social (Ibid. p.44). Para Cuff (2003) esse espaço pós-moderno é caracterizado pela coexistência entre o cyburg e o ciberespaço. As possibilidades geradas pela computação pervasiva reestruturam modos de vida e proporcionam novos significados ao espaço urbano e vínculos sociais.

Através desse breve panorama, pode-se verificar uma crescente indeterminação da fronteira entre instâncias virtuais e físicas, dada pelas relações de diálogo entre essas duas instâncias. Considera-se que o continuum entre "ambiente físico" e "ambiente virtual" não se apresenta mais de maneira nítida devido ao crescente uso cotidiano de tecnologias da comunicação e informação. Cadeias de ações e reações são criadas entre essas duas instâncias, tornando-as interdependentes.

os mecanismos para ampliação das nossas relações espaciais têm sido capacitados pelas TICs e, como tal, representam claras manifestações das características híbridas ambíguas do espaço e tecnologia no mundo urbano contemporâneo $^{29}$ (FIRMINO; DUARTE; ULTRAMARI, 2011, p.10)

Ainda que questões como comunicação remota não sejam algo novo, uso intenso dos meios digitais e eletrônicos confere um estado de reconfiguração e diálogo entre instâncias virtuais e concretas. Dessa maneira, devido a essa mútua influência, virtual e concreto não podem mais serem vistos como diametralmente opostos superando o caráter dualista de contraposição que os termos podem indicar. As mudanças contemporâneas ocasionadas por esses usos vão além da questão do remoto, da presença de imagens eletrônicas ou digitais, aparelhos digitais, interfaces sonoras. São transformações dadas pelos usos, adaptação e persistência desses meios, pois estes agem sobre as relações comunicativas, incluindo pessoas e criando canais de comunicação e diálogo.

\footnotetext{
${ }^{29}$ Tradução nossa. "[...] the mechanisms for augmenting our spatial relations have been empowered by ICTs and, as such, they represent clear manifestations of the ambiguous hybrid characteristics of space and technology in the contemporary urban world."
} 
A questão da relação entre dados digitais e instâncias físicas também é abordada por Lev Manovich (2009), que realiza uma abordagem mais ampla do que David Bennahum (1998 apud MANOVICH, 2009) sobre o conceito de cellspace, referindo-se à inserção de dados digitais do espaço físico. Manovich (2009) chama de dataspace a transformação ocorrida entre espaço físico e dados digitais. Essa transformação pode se dar por duas vias: considera que fatores como vigilância extraem dados digitais do espaço, ou seja, transformam o que ocorre no espaço em registro, dados digitais; por outro lado, considera que mídias locativas, internet, telas eletrônicas inserem informações digitais no espaço, onde uma camada de informação é colocada sobre o espaço físico.

Tais conceitos de Manovich (2009) exemplificam de forma simples o processo de dupla via na relação entre espaço físico e dados digitais. No entanto, essa justaposição pode se caracterizar mais como um adensamento entre instâncias virtuais e físicas.

Adriana Silva (2006) discorre que o digital nunca foi realmente separado do físico, e que há crescente indefinição nas fronteiras entre espaços digitais e físicos, promovendo mudanças em padrões de comunicação e sociabilidade. O espaço híbrido também é um espaço em rede (networked space), criado por pessoas e tecnologias móveis que operam em espaços geograficamente distintos e descontínuos (SILVA, 2006, p.272). O uso de meios digitais pode combinar dois espaços físicos distintos, criando situações de interações entre os locais e seus habitantes, transformando também relações sociais e os próprios espaços os quais inscrevem o uso. Há uma justaposição, portanto, entre as instâncias físicas e virtuais, criando interrelações e ocasionando hibridizações entre essas instâncias.

Sob esse panorama, reforça-se a ideia de que a instância híbrida é dada através do uso de meio digitais na vida cotidiana e pode ser verificada em uma escala crescente (SANTOS, Denise, 2008, p. 23). O espaço arquitetônico adensa-se, também composto por instâncias virtuais que conferem à sua natureza concreta um caráter híbrido (TRAMONTANO, 2007, p. 49). A hibridização de instâncias virtuais e concretas, conferida pelo uso de meios digitais e eletrônicos, também pode ser vista como potencializadora do processo de trazer características não aparentes desses espaços, transformando percepções sobre espaços urbanos através da elaboração de outras formas de interlocução.

Portanto, consideram-se entornos híbridos provenientes dessa relação de mutualidade e interdependência entre instâncias concretas e virtuais, derivadas de relações intrínsecas 
entre essas instâncias, auxiliadas pelo uso de meios digitais e eletrônicos, que têm usos e apropriações cada vez mais presentes em atividades cotidianas. Devido essa simbiose, relações entre concreto e virtual não se dão como contraposição, adição, adereço ou complementaridade, portanto enfatiza-se aspectos relacionados à interdependência entre essas duas instâncias - também dada através uso de meios digitais e eletrônicos.

\section{Difração: uso de interfaces}

A partir da consideração de que o espaço é heterogêneo e possuidor de dinâmicas e atividades, considera-se que seus processos inscritos se organizam de uma maneira própria e característica. Dessa forma, o uso de interfaces se apresenta como um campo onde tais características do espaço devem ser consideradas, pois interfaces influenciam em dinâmicas do espaço, conferindo caráter híbrido.

Conceito sobre interface é discutido em variadas áreas do conhecimento, tendo seus objetivos delimitados e definidos de acordo com campos de interesse. No entanto, tais objetivos referentes às interfaces aplicados por variados campos disciplinares nem sempre são desejáveis quando se trata do contexto sonoro, pois aspectos como variabilidade e aleatoriedade podem ser desejáveis, bem como transparência e invisibilidade podem não ser premissas úteis quando se abordam contextos das interfaces sonoras. Devido à vasta bibliografia sobre conceitos de interface, propõe-se aqui uma noção abrangente de interface, não delimitada ao seu aspecto tecnológico ou da interface como um objeto físico. Essa abordagem possui dois lados. Uma noção abrangente de interface, por um lado, pode tornar o conceito amplo, por outro lado, atende-se outras características que vão além da interface humano-computador, criando possibilidades para outras reflexões e uma revisão de objetivos e características da interface.

Sendo assim, opta-se por uma aproximação mais humana à interface, enfatizando sua importância crítica e reflexiva e levantando questões referentes às Ciências Humanas e da Comunicação, em contraposição aos conceitos de interface estabelecidos pelo campo disciplinar da Interação Humano-Computador. Consideram-se importantes as formas de comunicação e expressão criadas pelas interfaces, dando suporte também ao caráter humano. Por exemplo, em uma comunicação remota através do computador, o que 
interessa à presente pesquisa não é a relação entre o usuário e a programação, os objetos computacionais, e sim as possibilidades determinadas pelo computador no estabelecimento de interlocuções entre um e o outro. De maneira geral, interlocuções condicionadas pelas interfaces não só entre humano-máquina, mas também são entre pessoas.

Para Zielinski (1997),

A interface determina a relação entre um e o outro, o qual é diferente e fundamentalmente desconhecido, e vice-versa: através da interface um se apresenta ao outro, e faz isso em respeito aos aspectos que são compreensíveis $^{30}$.

Pode-se considerar que interface não é necessariamente um limite, e sim um campo onde é possível agência e atuação, estabelecendo relações entre duas partes e sendo responsável por diálogos entre o indivíduo e o outro. Ao mesmo tempo em que interfaces denotam uma separação, também são responsáveis pela construção de um locus comunicativo de ações e reações. Como Zielinski (1997) afirma, a interface conecta e separa, pois sem essas características ela perde o sentido de ser. Separa, pois é requerida para uma interlocução entre elementos que previamente não se entenderiam ou possuem desconexões.

Assim, pode-se primeiramente afirmar que interfaces estabelecem aberturas que possibilitam interlocuções entre duas instâncias. Steven Johnson (1997, p.17) entende que a interface atua como um tradutor, mediando duas partes e tornando uma sensível a outra. O autor considera apenas a interação entre pessoa e computador, e se refere a softwares que dão forma à essa interação, onde "a relação governada pela interface é uma relação semântica, caracterizada por significado e expressão, não por força física" (JOHNSON, 1997, p.17, grifo do autor).

Lev Manovich (2001) se aproxima dos termos de Johnson (1997), tendo em mente a interface-humano-computador. Utilizando-se do termo "interface cultural", Manovich (2001) descreve-as como "interface-humano-computador - modos os quais computadores apresentam e permite-nos a interagir com dados culturais" ${ }^{31}$ (Ibid., p.70), nas quais a

\footnotetext{
${ }^{30}$ Tradução nossa. "The interface determines the relation of the one to the other which is different and fundamentally unknown, and vice versa: through the interface the other presents itself to the one, and does this with respect to those aspects that are understandable."

${ }^{31}$ Traduçãonossa."a human-computer-interface - the ways in which computers present and allow us to interact with cultural data."
} 
linguagem é formada a partir de formas culturais familiares (Ibid., p. 79). Manovich (2001, p. 69) também constata que a distribuição das formas de cultura crescentemente tem se dado por meios digitais, de forma que "já não estamos mais à interface com um computador, e sim à cultura codificada de forma digital" ${ }^{32}$ (MANOVICH, 2001, p. 69-70). Ou seja, não se lida somente com uma máquina, com suas interfaces físicas como o mouse e o teclado, e sim se lida com um conteúdo cultural.

Manovich (2001, p.66) identifica que a cultura computacional produz números de interfaces variadas para se relacionarem ao mesmo "conteúdo", em que os dados informacionais podem se referir a diversas representações. Isso implica, portanto, uma conexão de domínios diferentes através do computador, que pode "conectar diferentes tipos de mídias exibidos utilizando uma só máquina”"33 (MANOVICH, 2001, p. 51). A partir dessa consideração, a interface apresenta-se como inseparável do conteúdo (Ibid., p.67). Apropriando-se do pensamento de Manovich (2001) sobre interfaces culturais, notam-se relações que transpassam o âmbito do computador. Trata-se de uma marcante característica de meios digitais de possuírem leitores de formatos de diferentes naturezas, sendo possível realizar conexões multimodais, explorando através de uma mesma interface sons, visualizações, interações hápticas, dentre outros. Essa característica é aproveitada no âmbito da arte digital, instalações e intervenções. Além disso, sendo dotadas de conteúdo cultural, essas interfaces concorrem para a alimentação do debate público, pois proporcionam meios para a formação de um loci de comunicação.

Jay Davis Bolter e Diane Gromala (2003) consideram a arte digital como uma boa forma de design de interface, considerando como interface a face que o dispositivo apresenta aos seus usuários. Nesse conceito, Bolter e Gromala (2003) tratam como janelas e espelhos para convergir duas perspectivas diferentes: janelas como metáfora para interfaces que auxiliam o enquadramento de nossa visão, nossa perspectiva, como também uma extensão do que pode ser visto; o espelho como uma metáfora para a interface reflexiva, que auxilia o usuário entender seu próprio contexto. Tais metáforas também consistem em uma interface que não é invisível e que seja adaptável. Os meios digitais não são neutros, eles reconfiguram e transformam e também são formados por instâncias físicas e contextos culturais.

Para Bolter e Gromala (2003, p. 26-7) as interfaces não podem, nem devem, ser

\footnotetext{
${ }^{32}$ Tradução nossa. "we are no longer interfacing to a computer but to culture encoded in digital form."

${ }^{33}$ Tradução nossa. "[...] diferent media types to be displayed using one machine [...]".
} 
totalmente invisíveis ou transparentes: através da combinação de janelas e espelhos, estar entre a invisibilidade e a reflexividade, há a possibilidade de outras formas experimentais em que o design da arte digital se dá de modo a favorecer a experiência do usuário (BOLTER;GROMALA, 2003). Além de trazer o contexto do interator ao uso de meios digitais, interfaces devem também se adaptar a esses contextos, realizando uma interlocução.

Trata-se de uma relação em que o interator é ciente de seu contexto e do uso aplicado à interface, direcionando a um processo em que o contexto é redefinido através da interação entre interface e interator (BOLTER; GROMALA, 2003, p. 27).

Essa relação indicada por Bolter e Gromala (2003) estabelece um processo responsivo no qual há processos de adaptação e readaptação entre interfaces e interatores. Portanto, refere-se da consideração de um conjunto de interações que não reflete somente pergunta-resposta, ou ação-reação, e sim processos de interlocução e conversa.

A interface, tendo em vista reflexões sobre tais abordagens (MANOVICH, 2001; JOHNSON, 1997; BOLTER; GROMALA, 2003), não trata de eliminação de camadas, e sim de uma conexão de domínios criando canais de comunicação em um sentido amplo.

Aproveitando-se de tais abordagens, de uma forma semântica, interface apresenta-se como um "tradutor" que adapta "linguagens"; contudo, que vai além do modelo estímulo/resposta, estabelecendo condições para gerar um locus onde partes se comunicam. A interface realiza transformações de estados, representações e interlocuções. Interlocuções, pois não somente se dão ações reativas, pontuadas entre ação e resposta, e sim ações que geram transformações. Tal conexão entre instâncias físicas e virtuais auxiliam no processo de construção de entornos híbridos, estabelecendo um locus comunicativo entre domínios através da interface. 
Imagem 3: Wooden Mirror, de Daniel Rozin, no Museu de Israel, 2004.

Fonte: site do artista. <http://www.smoothware.com/da nny/woodenmirror.html>. Acesso em 13 de jun. de 2013

Peter Weibel (2000) utiliza conceitos da endofísica de Otto Rössler para discorrer sobre um conceito ampliado de interface. Um dos princípios fundamentais da endofísica é a consideração do observador como atuante em sua observação, ou seja,

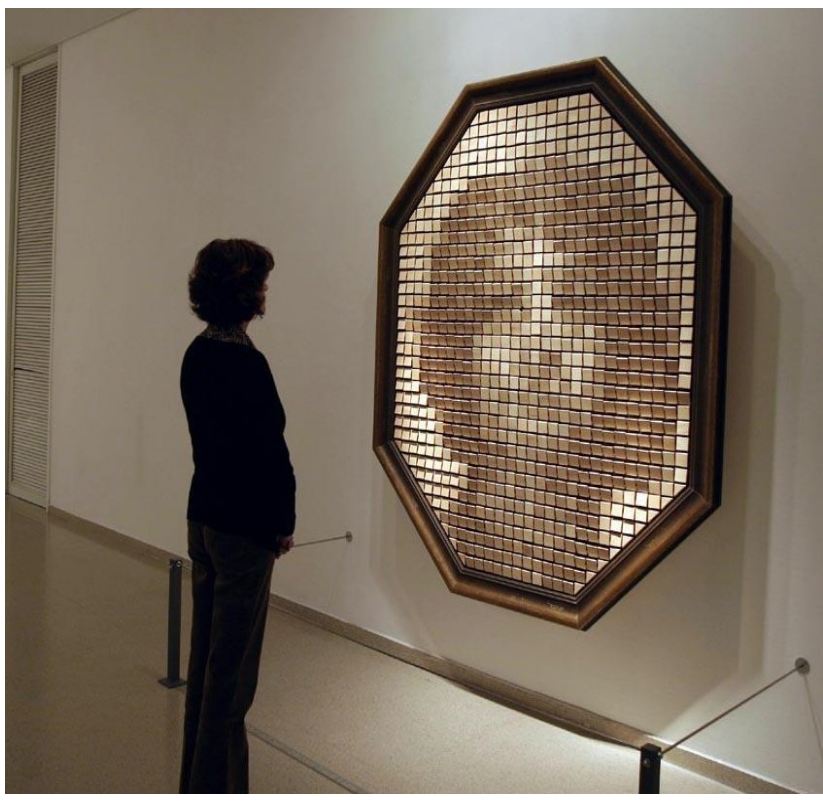
investiga aspectos de uma observação na qual o próprio mesmo está inserido. "Enquanto seres humanos formamos parte de um mundo que também somos capazes de observar. Portanto, só podemos percebê-lo de seu interior"34 (WEIBEL, 2000, p.28). A ideia de que o observador sempre faz parte daquilo que observa coloca em questão a existência da objetividade, devido à relatividade do observador. Somos parte do sistema que observamos ou interagimos, Weibel (2000) retrata que a tecnologia eletrônica, e podemos dizer também os meios digitais, nos fazem compreender essa condição.

Esses meios são parte de tecnologias de "presente expandido" (WEIBEL, 2000, p. 25), no sentido de que são modos de transcender o horizonte local tornando coordenadas de espaço-tempo mais maleáveis. Assim, o presente não é mais uma experiência limitada, podendo ser uma experiência simultânea e sem localidade geográfica específica. O uso de interfaces auxilia o pensamento e a compreensão do mundo em que vivemos, colocando em evidência instâncias nem tão noticiáveis para elaborar um entendimento epistemológico do mundo.

É criada a oportunidade de ir ao outro lado da interface para compreender de certa forma "as distorções específicas do observador que se produzem em nosso próprio mundo" 35 .

\footnotetext{
${ }^{34}$ Tradução nossa. "Encuanto seres humanos, formamos parte de um mundo que también somos capaces de observar. Por tanto, sólo podemos percibirlo desde su interior."

${ }^{35}$ Tradução nossa. "surge la possibilidade de ir al otro lado de la interfaz y desentrañar em parte las distorsiones específicas del observador que se producen em nuestro próprio mundo".
} 
Isso se trata, nas palavras de Weibel (2000), de olhar atrás da cortina.

Tratam-se de formas que auxiliam o pensamento epistemológico do mundo, dando "as pistas e os insights necessários", pois "as artes interativas, com suas interfaces, explicitam e colocam em evidência uma dimensão epistemológica que vai além da própria estética, já que elas servem de modelo para entender a maneira como nos relacionamos com 0 mundo" (ARANTES, 2005, p. 73). Nessa relação, proposta por Priscila Arantes (2005) sobre o pensamento de Weibel (2000), os domínios envolvidos pela interface se dá em inter-relação, e não podem ser vistos separadamente pois há uma influência recíproca.

Essa questão da arte eletrônica colocada por Weibel (2000), e também dos meios digitais, de certa forma também caracteriza a questão da reflexividade da interface colocada por Bolter e Gromala (2003). As interfaces, colocadas no âmbito da arte eletrônica e digital, podem proporcionar entendimento do contexto do observador, que pode ser capaz de enxergar seu próprio contexto através da interface. Esse processo não se dá de maneira súbita, no entanto pode levar à elucidações instantâneas ou futuras: trazer à tona o que não era antes tão notável e gerando um entendimento.

Perspectivas diferentes podem ser aproximadas através dos meios digitais e eletrônicos. A função a interface vai além do modelo reativo: ela conecta e possibilita trocas, sem exigir a eliminação ou invisibilidade de suas camadas. É através dessas camadas das quais se obtêm espelhos e janelas (BOLTER; GROMALA, 2003) para auxiliar compreensões diversas. Assim, interfaces possuem o potencial de instaurarem um locus de comunicação, estimulando e estabelecendo interlocuções que podem demonstrar aspectos não aparentes ou demarcados.

O adensamento do espaço físico arquitetônico, trazido pelo uso de meios digitais, também se dá através de interfaces sonoras que, eletrônica ou digitalmente, sobrepõem instâncias concretas e virtuais, modificando modos de escuta e produção sonora. Justaposições entre entornos sonoros e entorno físico promovem diferentes relações entre pessoas, som e entorno. Na presente pesquisa considera-se que entornos híbridos são decorrentes da justaposição de entornos sonoros e físicos, a qual é auxiliada pelas interfaces sonoras.

A consideração das interfaces sonoras apenas como elementos geradores ou reprodutores de som torna o conceito tecnicista, além de aglomerar uma infinidade de objetos concretos ou desmaterializados, musicais ou não, meios acústicos, eletrônicos e digitais em uma única categoria. Também não convém considerar interfaces sonoras 
como apenas dispositivos tecnológicos que transduzem, codificam ou decodificam dados informacionais relacionados a som, qualificando interfaces apenas como instrumentos de mediação tecnológica, às vezes muito pontuais sem a consideração do todo.

A interface pode ser formada por objetos físicos, contudo não se restringe somente a eles; também pode se apresentar como um conjunto de elementos associados, onde o importante é a criação de interlocuções através do uso desse conjunto.

Tendo em mente tais reflexões, interfaces sonoras podem ser percebidas como formas que auxiliam a compreensão do mundo, criando condições para a formação de um locus de comunicação. Além disso, o conjunto de elementos associados à interface proporcionam uma conexão de domínios, onde o som possui papel que não pode ser descartado.

Interfaces sonoras promovem interlocuções, transformando ou criando outras formas de escuta e produção sonora. Conseguem também ampliar a diversidade de entornos sonoros através da mediação tecnológica, pois o ouvinte não se encontra mais limitado ao seu entorno sonoro sem mediação, ou seja, não é mais necessária a aproximação física entre ouvinte e fonte sonora ao mesmo tempo. Com uso de meios digitais, relações espaciais se complexificam devido suas influências, além das possibilidades trazidas quanto à interatividade e interlocução interdependente entre instâncias virtuais e concretas.

Por fim, para produzir compreensões sobre constituição de entornos híbridos em relação a instâncias sonoras, é interessante entender sua composição como um conjunto de ações e reações que fazem com que elementos envolvidos influenciem-se mutuamente. O som, como elemento do espaço, também é um elemento envolvido nessas dinâmicas. Em práticas sonoras, como instalações e intervenções sonoras, o som toma papel central e tem suas relações com o todo modificadas pelas interfaces, e também é influenciado por elas. O uso de interfaces contribui para a constituição de canais de interlocuções, fazendo surgir outros significados e constituindo um locus. Trata-se de aproximar e colocar elementos em contato, evidenciando características antes não tão notáveis.

Interface, nesse contexto de interdependência entre virtual e concreto, é responsável por uma conexão de domínios, pela comunicação entre elementos como objetos concretos, instâncias desmaterializadas e agência humana. A interface não resume-se em somente um aparato ou dispositivo, no entanto ela pode ser um conjunto de elementos associados, 
que possibilitam tal conexão entre domínios. Criando condições para interlocuções entre pessoas, ou entre pessoas e meios digitais, a interface não promove apenas características reativas, de uma maneira simplificada, mas quando utilizadas de modo qualitativo podem criar um locus de comunicação.

Assim, sob a luz desses aspectos, as interfaces auxiliam a instauração de entornos híbridos e quando utilizadas de maneiras qualitativas em espaços públicos podem promover tais locus de comunicação. Além disso, o uso de tais interfaces podem promover diferentes atividades em espaços públicos, alterando a relação entre pessoas, entorno e som. A justaposição de entornos sonoros e físicos vem em decorrência do estabelecimento de entornos sonoros virtuais e também dos aspectos tecnológicos em relação ao som e áudio, que modifica variadas características de entornos sonoros e tendo participação no processo de conceituação e atuação da interface.

\section{Reflexão: Consequências dadas pelo aspecto}

46 tecnológico

Sons podem ser captados, mixados, transmitidos ou masterizados e arquivados, através de processos tecnológicos que podem manipular sua natureza, transformando-o.

[...] as tecnologias de reprodução modernas utilizam dispositivos chamados transdutores, os quais transformam som em algo e esse algo novamente em som. Todas tecnologias de reprodução sonora trabalham através do uso de transdutores. [...] Todas tecnologias digitais de reprodução sonora usam transdutores; elas apenas adicionam outro nível de transformação, convertendo corrente elétrica em uma série de zeros e uns (e vice-versa) (STERNE, 2003, p. 22) ${ }^{36}$

Passando por processos variados de transdução, o som de natureza mecânica é transformado em diferentes naturezas (eletrônicas ou digitais) para ser novamente transformado em som acústico, através de falantes. Essa transformação de som em

\footnotetext{
${ }^{36}$ Tradução nossa. "[...] modern technologies of sound reproduction use devices called transducers,which turn sound into something else and something else back into sound. All sound reproduction technologies work through the use of transducers. [...] Digital sound-reproduction technologies all use transducers; they simply add another level of transformation, converting electric current into a series of zeros and ones (and back again)."
} 
áudio, e vice-versa, é essencial à acessibilidade da escuta por conferir reprodução e repetição. É também a partir da possibilidade de transdução que é possível a complexificação dessas relações de mediação, indo além das possibilidades de reprodução e amplificação, instaurando diferentes aspectos nas relações entre sons, produção sonora e escuta. Tais processos inscrevem em si também processos sociais, implicando em "relações sociais entre pessoas, máquinas, processos, e sons" 37 (STERNE, 2003, p. 219). Dessa maneira, a ideia de transdução como um fenômeno inerente à mediação marca uma alteração na relação entre fonte sonora original, som e escuta, ao invés de uma dissociação (FERREIRA, 2012). Ou seja, a ideia de transdução marca uma diferenciação dessa relação.

Tais processos, banais e cotidianos, o entorno sonoro é modificado por mediação tecnológica. A escuta não está mais confinada ao espaço físico contínuo, não é necessária proximidade de algo para poder ouvi-lo. De certa forma, não é mais necessário "ver para poder ouvir". Há a dissociação temporal e espacial, ainda que não seja equiparada ao original, possuindo diferenciações. Essa questão refere-se diretamente à escuta acusmática. Dessa forma, a escuta acusmática pode ser definida como cotidiana, pois os alto-falantes ou fones de ouvido não se configuram como a fonte sonora primária do som e sim como tecnologias que reproduzem sons. Ao mesmo tempo em que essas interfaces conferem acessibilidade à escuta, conectando ouvinte e a reprodução da fonte sonora, elas os separam, realizando um deslocamento espaço-temporal através da inserção de processos tecnológicos.

Técnicas como processamento e mixagem oferecem ao compositor a oportunidade de obscurecer sons do mundo real, e assim negar nosso acesso fácil a indícios referenciais sem romper inteiramente nossa conexão com a fonte. Elas podem guiar-nos em uma viagem perceptual sinuosa na qual suas re-percepções do som nos dirige à nossa própria escuta criativa $^{38}$ (NORMAN, 1996, p. 20).

Podem ser percebidos forjamentos desses entornos sonoros através de gravação, reprodução e transformação do sinal de áudio através dessas mediações tecnológicas referentes à reprodução sonora. Através desses processos, o som ouvido não é mais

\footnotetext{
${ }^{37}$ Tradução nossa. "[...] sound reproduction - from its very beginnings - always implied social relations among people, machines, practices, and sounds."

${ }^{38}$ Tradução nossa. "Techniques such as processing and mixing give the composer the opportunity to obscure real-world sounds, and so deny our easy access to referential clues without entirely severing our contextual connection with the source. She can guide us on a circuitous perceptual journey in which her re-perceptions of the sound direct our own, creative, listening."
} 
inteiramente correspondente ao espaço físico de sua captação, como comumente pode-se perceber em produtos fonográficos musicais. Um estúdio musical pode simular comportamento acústico dos sons dos instrumentos, bem como a distribuições do som nos canais, levando o ouvinte para um entorno sonoro desejado pelos músicos e produtores musicais.

Tecnologias de reprodução sonora, e também fenômenos inscritos à transdução sonora, propiciam manipulação e edição de características físicas do espaço contidas no som. Ainda que determinadas mudanças drásticas das características do som gravado podem direcionar a um resultado artificial, é possível criar e simular entornos sonoros através do uso dessas tecnologias. Esses entornos sonoros são construções possibilitadas pelos processos de mediação tecnológica, possibilitam o surgimento de interfaces que influenciam no relacionamento entre ouvinte, entorno físico e sonoro.

Tanto dimensões interativas quanto responsivas em práticas sonoras importantes ao presente estudo mostram-se como fatores importantes facilitados pelo uso de meios digitais. As maiores diferenças entre esses usos refletem-se principalmente através de sistemas de produção sonora, transmissão e na diversidade de elementos de interação.

48 Meios digitais e eletrônicos possibilitam a não necessidade do som corresponder acusticamente ao corpo físico de sua fonte sonora original,podendo ser transformado ou gerado de forma eletrônica ou digital, além de inserir elementos de outras naturezas em um sistema de interação, como movimento, luz, tato, dentre outros.

Através da mediação tecnológica de dispositivos digitais acentua-se atuação de instâncias virtuais, transformando também métodos para criação e escuta sonora. Usos de meios digitais também propiciam variabilidade de materiais e de elementos, tanto de manipulação quanto de resposta, que podem caracterizar estruturas mais complexas entre criação sonora e escuta, bem como interação.

Outra possibilidade referente à mediação tecnológica através do uso de meios digitais reside nas formas de transmissão. Ainda que a transmissão de sons não seja confinada à transmissão de dados digitais, afinal por exemplo o telefone e o rádio são formas de transmissão que datam do início do século XX, a comunicação remota via internet confere outras possibilidades que trazem questões ligadas à constituição de entornos híbridos. Além da correlação entre entornos sonoros e locais geograficamente distintos, os diferenciais se encontram na facilidade de trocas e nos processos colaborativos no que condiz a respeito de criação sonora e escuta. 
Podemos reinterpretar os deslocamentos acusmáticos de gravação, telefone, rádio e sínteses como casos da tecnologia aproximando lacunas ao invés de criálas - a possibilidade de tornar as pessoas mais próximas, especialmente em suas mais recentes versões que incluem interatividade e dimensões responsivas. Portanto enquanto as conexões locais parecem quebradas pela tecnologia, mandamos um e-mail ou um texto a alguém da sala ao lado - espaços e tempos distintos podem se juntar, a rede emerge ${ }^{39 .}$ (EMMERSON, 2012, p.10).

Transformações quanto à abrangência e interrelações entre entorno sonoro e físico são propiciadas por tecnologias que permitem um processo colaborativo. A criação sonora via internet, por exemplo, proporciona condições que enfatizam questões de colaboração. Há incorporação de redes de informação para conjuntos de práticas sonoras, permitindo interação simultânea entre participantes em locais geograficamente distintos. Tais trocas em rede permitem práticas em múltiplas localidades, não somente através do uso de computadores como também através de aplicativos e dispositivos como celulares.

Participantes podem realizar trocas sonoras entre si em locais geograficamente distintos, ou características próprias de uma localidade podem interferir em outra, de forma remota e síncrona, dentro dos limites técnicos e de latência, proporcionando integração entre entornos físicos geograficamente distintos através do som. A incorporação espacial de tecnologias promove maior acesso e possibilidades para se trabalhar essas questões, também em intervenções sonoras, que serão discutidas no segundo capítulo.

\section{Propagação: Ouvindo junto}

Pensemos na seguinte situação: uma pessoa volta de seu trabalho à sua casa ouvindo, no rádio, uma entrevista feita "ao vivo". Chegando em casa, decide escutar música, pluga o tocador de mp3 no seu sistema de caixas de som e escolhe uma música do material que

\footnotetext{
${ }^{39}$ Tradução nossa. "We can reinterpret the acousmatic dislocations of recording, telephone, radio and synthesis as cases of technology bridging gaps rather than creating them - the possibility of bringing people closer together, especially in their more recent versions which include interactive and responsive dimensions. Thus while local links appear broken by the technology, - we send an e-mail or text to someone in the adjoining room - far removed spaces and times can join up, the network emerges."
} 
possui. Quando começa a ouvir música, o celular toca. A pessoa interrompe a música e atende, iniciando uma conversa com outra que está, por exemplo, a $200 \mathrm{~km}$ de distância.

Todos esses processos no exemplo acima estão longe de serem novos, porém todos eles implicam em uso de interfaces sonoras que promovem alterações quando comparados à escuta direta de um som, no qual se faz necessária a aproximação do ouvinte à fonte sonora. O ouvinte não se encontra no estúdio da emissora de rádio, nem ao mesmo tempo em que a banda no estúdio de gravação, nem fisicamente próximo ao interlocutor da conversa telefônica. Tampouco essas reproduções, nos dois primeiros casos, correspondem ao som propriamente dito: tanto a entrevista quanto a gravação fonográfica tiveram suas condições direcionadas para o seu formato final, para a linguagem que o formato final requer: para isso, os sons foram capturados, mixados, transmitidos ou masterizados e arquivados. Nesses processos, tão banais e cotidianos, há a justaposição de outro entorno sonoro no espaço físico e ao seu entorno sonoro direto sem interfaces. A escuta não está mais confinada à continuidade geográfica, não sendo mais necessária proximidade da fonte sonora para poder ouvi-la.

Joshua Meyrowitz (1985, p.115) discorre que os meios eletrônicos dissociaram o "lugar" 50 físico do "lugar" social ${ }^{40}$, desvinculando onde estamos fisicamente de onde estamos socialmente. Marcus Foth, Jaz Choi e Christine Satchell (2011), em estudo mais recente que aborda meios digitais, discorrem que tecnologias cotidianas permitem interatividades independentes, transpassando fronteiras físicas e geográficas. A disjunção entre um lugar físico e social é exemplificada por William Mitchell:

Abra um livro, entre em um cinema, ou coloque uma música no seu iPod e sua atenção é instantaneamente direcionada para outro lugar ou espaço. A densa incorporação desses espaços midiáticos no tecido urbano produz uma cidade que, como um filme com jump cuts e flashbacks, é experienciada e entendida como uma sequência de cenas descontínuas - algumas delas expressões da realidade, do local atual, e outras construções efêmeras da mídia (2005, p.15).

O exemplo mais comum dessa justaposição refere-se à individualização da escuta. A audição hoje, devido ao uso de meios digitais e de fones de ouvido, está mais suscetível à escolha do ouvinte do que antes dessas tecnologias. O uso individual dos aparelhos de reprodução sonora portáteis tende à personalização da escuta, provendo uma esfera particular dentro da esfera pública da cidade. Os celulares e tocadores de mp3 são

\footnotetext{
${ }^{40}$ Nessa referência, preferiu-se manter a tradução de "place" como "lugar".
} 
particularmente influentes para criação de um entorno sonoro particular, pela sua portabilidade e por ser uma possibilidade de fuga dos sons da cidade, dos sons do outro. O ouvinte através da escuta individualizada pode ser indiferente, isolado, apesar de estar cercado de pessoas.

É possível observar que o som desconexo de sua fonte de origem no espaço concreto é proporcionado principalmente pelas telecomunicações, o que implica em transmissão remota analógica ou digital de conteúdos simultâneos ou reproduzidos. Em aparelhos de reprodução sonora, como tocadores de $m p 3$, é possível a repetição o mesmo conteúdo diversas vezes de acordo com os desejos do usuário. Os processos de reprodução possibilitaram armazenamento e repetição, permitindo controle do fluxo temporal pelo ouvinte, também acarretando em uma possível fragmentação (IAZZETTA, 2012, p.14), no sentido de que o ouvinte encontra muitas vezes possibilidades de interromper tal escuta quando deseja.

Com a onipresença de meios de reprodução sonora e da escuta individual, criam-se entornos próprios e personalizáveis, em detrimento do entorno sonoro não mediado.

$\mathrm{Na}$ escuta individualizada, o som é direcionado ao ouvinte que personaliza sua escuta escolhendo, por exemplo, seu gênero música preferido em detrimento da audição de seu entorno sonoro. Os sons relativos a transportes e trabalho somam-se aos sons de diversão, entretenimento e de abstração à situação do deslocamento, caracterizando-se como uma alternativa de fuga e abstração àquela situação, uma reconfiguração da intimidade (BULL, 2000); ou, como aponta Edward Hall (1977), uma forma de privação dos sentidos para suportar a aglomeração. Segundo Jonathan Sterne (2003), a prática individualizante da escuta é uma forma burguesa da escuta, pois os ouvintes podem ouvir seus próprios espaços acústicos, tornando o espaço de escuta em uma propriedade privada em que o ouvinte habita sozinho, estabelecendo relação de alheamento com entorno. Com uso desses meios de reprodução sonora individuais, criam-se entornos próprios e personalizáveis, em detrimento do entorno sonoro que se dá de maneira coletiva. No entanto é importante ressaltar que a reprodução sonora não é entendida como um aspecto negativo, porém tecnologias e seus processos derivados não são neutros (STERNE, 2003).

Ainda fundamentando-se em conceitos para tal afirmação, têm-se no termo audile technique, ou techniques of listening (STERNE, 2003, p.23, 90-96), que pode ser traduzido como técnicas de escuta, a referência a esse conjunto de práticas culturais 
inerentes às tecnologias de reprodução sonora, que também proporcionam direcionamento qualitativo. Nesse termo, a técnica conota também conexão entre prática, tecnologia e instrumentalidade, como também possibilidade de falha e acidente. Nesse contexto, a técnica auditiva não é uma representação do espaço da escuta e sim um elemento atuante: "O espaço ocupado por sons torna-se algo para ser formado, moldado,

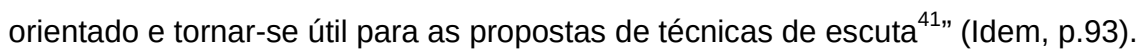

Considera-se como escuta coletiva a ação do entorno sonoro que é comum a mais de um ouvinte, que age em determinado local e tem sua atuação de modo expansivo, seja sem ou com o uso mediação tecnológica. É o oposto da escuta individual, personalizada. Além de atingir maior público e posteriormente também participação, considera-se que a escuta coletiva coloca em detrimento a escuta individualizada, trazendo a atenção das pessoas ao espaço compartilhado no dado instante. A difusão sonora é a projeção e distribuição de sons (SMALLEY apud AUSTIN, 2000), que expande geograficamente a atuação do entorno sonoro, agregando ouvintes.

Como essa escuta não está limitada aos fones de ouvido, pode agir em diferentes escalas do entorno sonoro. Dessa forma, estabelece o som como fator em comum às pessoas 52 presentes em determinada porção de espaço físico, tornando-se fator em comum entre elas. Através do uso de formas de transmissão, tais como rádio ou internet, essa escuta pode-se referir a pessoas que estão em locais distintos, não havendo a necessidade de haver continuidade geográfica.

Junto à difusão sonora, a escuta coletiva favorece a constituição de entornos híbridos e o alcance de interfaces, de forma que estabelecem um locus de comunicação.

Através da escuta coletiva amplia-se a abrangência do espaço de escuta. Essa abrangência também pode se dar de forma descontínua em relação ao espaço concreto através das formas de transmissão, podendo interferir em locais geograficamente distintos de forma simultânea. A amplificação, em práticas sonoras relacionadas à pesquisa, possui papel importante pois dependendo de como as interfaces atuam não permitem somente uma ampliação do espaço de escuta, como também de atuação do ouvinte.

Em espaços públicos, interfaces podem inserir aspectos sobre a rotina cotidiana,

\footnotetext{
${ }^{41}$ Tradução nossa. "The space occupied by sounds becomes something to be formed, molded, oriented, and made useful for the purposes of listening techniques."
} 
ocasionando práticas inusitadas, ou até mesmo um estranhamento ao cotidiano. Tais diferenciações podem se comportar como fomento à outra utilização de espaços públicos, ou trazer à tona aspectos e características que não eram facilmente percebidos pelas pessoas que utilizam o espaço; atuando como um ponto convergente que pode promover atividades sociais entre pessoas, como será discutido no próximo capítulo.

Portanto, a elaboração de formas de escuta coletiva também reflete uma preocupação sobre a utilização do espaço público. A fim de não reduzir a prática somente a uma esfera de pergunta-resposta, nem pessoas a consumidores, é interessante abordar aspectos referentes às práticas cotidianas, questões socioculturais, ou históricas do espaço. Através dessa consideração, significados mais profundos podem ser trazidos à prática. Para tanto, deve-se considerar aspectos que interfaces e processos de mediação tecnológica podem agregar nessa interrelação, tanto na leitura como na elaboração de intervenções sonoras. Dessa forma, afirma-se a condição intrinsecamente relacional entre som e espaço, realizando o foco nas relações que constituem entornos híbridos. Relações que são desencadeadas através da combinação de formas de escuta, participação, som e espaço, trazendo o espaço também como um interlocutor. 
54 
56 


\section{Práticas sonoras: \\ leituras de um campo extenso}

As leituras do presente capítulo auxiliam a compreensão das potencialidades do uso de interfaces sonoras em espaços públicos, não somente considerando valores artísticos, como também sociais e culturais. A constituição de entornos híbridos através da utilização de interfaces sonoras de escuta modo coletivo também pode ser fonte para a construção de conhecimento sobre relações entre pesquisa, espaço e som; formando um campo onde ideias e opiniões são discutidas. Para tanto, primeiramente são feitas algumas considerações sobre intervenções sonoras.

Saskia Sassen (2006) afirma que a arte e o trabalho de design podem auxiliar a capturar qualidades indescritíveis que as cidades produzem e torná-las aparentes, e tecnologias promovem amplitude a essa questão contribuindo para valorização de contextos existentes. Transferindo tal afirmação ao contexto sonoro, o uso de interfaces altera relações de produção sonora e escuta, acarretando em mudanças entre pessoas que possuem contato a elas, entorno e som, produzindo outras relações e interpretações do espaço, auxiliando a tornar aparentes outras qualidades do espaço, valorizando determinados contextos.

Interessa à pesquisa a atuação de interfaces sonoras em espaços públicos, constituindo uma intervenção, introduzindo mudanças em um contexto existente através do som. $\mathrm{Na}$ etimologia da palavra, intervenção possui relação com intervenire, relacionada com "sobrevir", "intervir", "meter-se de permeio" (HOUAISS, 2013). Trata-se de uma alteração, provida de uma dimensão contextual que transforma intencionalmente dada situação.

Segundo Nelson Brissac Peixoto (1998, p.12), refletindo sobre seu projeto prático que engloba intervenções de diferentes naturezas na cidade,

a intervenção é uma inscrição num fluxo mais amplo e complexo que é a dinâmica urbana, implica em entender a cidade como algo em movimento. Não na forma de vetor progressivo, orientado, mas em várias direções. 
A realização de intervenções deve considerar que o espaço físico possui dinâmicas, características e ações próprias inscritos. Dessa forma, confere-se a necessidade da consideração de variados elementos, sociais, culturais, artísticos, históricos, que podem dialogar com intervenções.

Intervenções podem ser entendidas como trabalhos que transitam entre o campo da Arquitetura e da Arte, que abarcam técnicas artísticas diversas, podendo se realizar sob a forma de dança, artes cênicas, artes visuais, dentre outros. Contudo, além da dimensão contextual, as intervenções tomam como ponto convergente sua abordagem ao espaço, seja físico ou suas dinâmicas.

As intervenções temporárias transitam por significados do espaço, sejam eles topográfico, social, histórico ou político. Baseados em locais específicos e em significados vinculados a eles, os projetos de intervenções temporárias estabelecem assim uma relação contextualizada com a cidade, chamando atenção para os seus arredores e convidando as pessoas envolvidas a explorar as complexidades, conflitos e potencialidades inerentes das localidades em questão (NIELSEN, 2013). Intervenções, segundo Nielsen (2013), relacionam-se com áreas urbanas onde estão posicionadas; o que, por sua vez, define o caráter do trabalho providenciar relações locativas, agindo in situ. Na pesquisa, considerase que essas relações estabelecidas entre a intervenção e o local não é necessariamente o que se pode denominar como site specific, e sim que há um respeito e consideração das dinâmicas prévias do espaço abordado.

Considerando interfaces como conectoras, instauradoras de um locus comunicativo onde partes se comunicam formando um todo interdependente, pode-se considerar que intervenções constituídas por interfaces propiciam não somente uma alteração intencional sob uma situação do espaço: são relevantes em uma dimensão epistemológica, pois conferem formação de reflexões e questionamentos sobre uma ordem estabelecida.

Intervenções em espaços públicos não devem ser apenas uma forma de entretenimento, pois podem abrir caminho para diversas reflexões, tanto do público quanto dos próprios pesquisadores ou artistas. Sua realização em espaços públicos faz com que a intervenção esteja imersa em um local que não é imparcial e possui seu próprio contexto e dinâmica. Assim, há uma comunicação de duas vias entre o espaço público e a intervenção: a dimensão contextual do espaço envolve a intervenção, que deve considerá-la; ao mesmo tempo em que a intervenção pode alterar momentaneamente dinâmicas que o espaço possui e apreensões que se tem do espaço. 
Os caminhos tomados pelas intervenções, que podem ser divergentes, contudo, apontam para a característica interdisciplinar e híbrida que esses trabalhos possuem, em variadas esferas, seja quanto ao uso de materiais sonoros, transmissão, teorias e conceitos que dirigem o trabalho, quanto à associação de diferentes inputs ou outputs além dos sonoros, além de formas de abordagem e ênfases. Por tais razões, na presente pesquisa não se pretende traçar um panorama histórico dessas obras, categorizando suas influências estilísticas, e sim refletir sobre alguns temas que estas práticas abarcam, suas ênfases, principalmente nas relações entre som, espaço e pessoas participantes, como ouvintes ou como produtoras.

Max Neuhaus é considerado pioneiro na criação de trabalhos sonoros dedicados a espaços específicos. A partir dos anos 1960 até a sua morte, em 2003, Neuhaus realizou obras nas quais o som desempenha papel fundamental no espaço, e vice-versa, Neuhaus (1994) considera esses trabalhos como "trabalhos sonoros [...] onde os sons são postos no espaço ao invés do tempo". ${ }^{1}$

Um dos interesses da presente pesquisa converge com a aspiração de Neuhaus de promover aprimoramento de atividades cotidianas através do som, em contraposição à interrupção de seu fluxo, papel muitas vezes exercido pela música (DANTO, 1991); assim, aproveita-se da situação cotidiana, sem as convenções ou regras mais rígidas que conduzem atitudes daqueles que vão a uma sala de concerto ou a um museu.

Intervenções podem ter características diversas: efêmeras ou permanentes; atemporais ou aproveitando-se de situações cotidiana específicas. No entanto, a escuta coletiva é considerada característica essencial, bem como o uso de meios digitais ou eletrônicos e sua aplicação em espaços públicos, em detrimento, por exemplo, da galeria de arte.

O entorno sonoro atua com e também através do espaço, tornando-se um dos elementos que influenciam a apreensão do espaço. Considerando o som como um elemento constituinte do espaço, o uso de meios digitais e eletrônicos pode alterar não somente a abrangência do som, através de caixas de som ou de redes de transmissão, como também elaborar entornos híbridos e modificar relações de escuta e produção sonora como, por exemplo, em intervenções em que o ouvinte também é produtor sonoro.

\footnotetext{
${ }^{1}$ Tradução nossa. "sound works without a beginning or an end, where the sounds were placed in space rather than time"
} 
A justaposição de instâncias concretas e virtuais, caracterizando entorno híbrido, pode agregar informações ao espaço e tornar aspectos não tão aparentes mais perceptíveis, e podem ser promovidos canais de contato e comunicação. Em uma intervenção, podem-se adicionar informações ao espaço, colocando o público em contato com contextos ou problemáticas antes desconhecidas ou não tomadas em consideração; além de estabelecer formas das pessoas se expressarem sobre o contexto apresentado. Assim, através do uso de interfaces em intervenções, é criado um locus de comunicação não palpável, que se forma através de seu uso e percebido através dele, que reelabora ações do espaço concreto e podendo reforçar a discussão de assuntos que são de interesse público, podendo reforçar o caráter público do espaço em que age.

São escolhidas no presente capítulo intervenções que se estruturam em torno de interfaces sonoras de diferentes tipos, que possuem como ponto comum a escuta coletiva e o fato de serem elaboradas para espaços públicos e neles executadas. A escolha de tais intervenções sonoras não foi realizada de forma a criar uma hierarquia ou apresentar relevância perante outros trabalhos aqui não mencionados ou discutidos.

Considerando que intervenções possuem um término determinado, foram escolhidos trabalhos que, além de possuírem significância para a pesquisa, também oferecem bibliografia, registros, entrevistas, dentre outros materiais disponíveis em sites para sua leitura, contudo, que não sejam frequentemente abordadas em profundidade em trabalhos acadêmicos.

Assim, preferiram-se trabalhos que contemplam conceitos abordados pela pesquisa realizados nas últimas décadas, cujos realizadores possuem formação plural e transitam por várias áreas. Primeiramente, há a apresentação das categorias sob as quais as intervenções são analisadas.

\section{Direcionamento qualitativo dado pelas interfaces sonoras}

Nessa categoria não se pretende analisar a sonoridade, o som propriamente dito, mas refletir sobre como processos de mediação da interface colabora qualitativamente com as 
intervenções.

Apesar dessa descrição técnica, interfaces sonoras vão além dos níveis tecnológicos, pois auxiliam e dialogam com a proposição da intervenção como um todo. Através do uso de interfaces, som apresenta-se como um elemento que completa a intervenção, auxilia e dialoga com sua proposição, inserindo-se no aspecto conceitual.

De acordo com Marcelo Tramontano e Denise Santos (2013, p.17) o uso de interfaces digitais "abriga a comunicação no virtual, estimulando-a no concreto, reforçando a vocação de lugar de trocas, de encontros humanos, de construção de opiniões, que o lugar público nunca deveria perder".

Junto ao uso de meios digitais e eletrônicos, o som, através da escuta coletiva, pode despertar diferentes apropriações do espaço; promover mediação entre pessoas que o ouvem; auxiliar retomada da memória e história; aproximar diversidades e pontos de vista distintos; tornar características do espaço mais notáveis ou criar novas ações a partir de instâncias virtuais; promover inter-relações entre localidades distintas; dentre outros.

Os processos conduzidos por interfaces incluem variados procedimentos: manipulação, transformação de sonoridade, reprodução, criação e recriação de sons sem origem acústica, de forma analógica ou digital. Os processos derivados tecnologicamente implicam em mudanças qualitativas na intervenção, pois inscrevem em si processos sociais, implicando em "relações sociais entre pessoas, máquinas, processos, e sons" (STERNE, 2003, p. 219).

Simon Emmerson (2007, p.xiv), realiza uma identificação das etapas da "revolução acusmática" ("acousmatic revolution", aspas do autor), que auxilia a identificação de processos tecnológicos: memória mecânica do som como a transformação do som em um formato físico estável, a priori, e sua reprodução mecânica; a amplificação eletrônica através da inserção de falantes eletrônicos para aumento da intensidade sonora, ainda que o desejo de fazer o som soar "mais alto" seja anterior à amplificação eletrônica; e por fim a síntese, a produção sonora sem origens notadamente mecânicas ou acústicas, ou seja, a criação de sons a partir de outras naturezas, como faz instrumentos como o telharmonium ${ }^{2}$, ondes

\footnotetext{
${ }^{2}$ Telharmonium foi criado por Thaddeus Cahill e teve três versões fabricadas, a primeira em 1897. Era um instrumento eletrônico baseado em linhas telefônicas.
} 
martenot $^{3}$ ou theremin ${ }^{4}$. Ampliando tal questão, podem ser considerados de instrumentos musicais como sintetizadores até programação computacional em softwares para produção sonora.

A memória mecânica do som está relacionada ao armazenamento, que acarreta um deslocamento espaço-temporal, ou seja, a fonte sonora original não precisa mais estar no mesmo tempo e espaço físico que o ouvinte. Além disso, memória mecânica do som subverte a questão da unicidade do som, pois possibilita repetição. A amplificação acarreta em uma maior abrangência do entorno sonoro e de escuta, pois sons mais intensos conseguem propagar-se em espaços concretos mais amplos e para audiências maiores, além de promover uma escuta compartilhada entre várias pessoas sob alcance do som reproduzido. A síntese, como referida nos termos de Emmerson (2007), auxilia na construção de um entorno sonoro com relação ainda menor quanto à materialidade, no sentido de que retira a obrigação da existência de uma fonte sonora concreta para inserir a criação de outros sons. Tais sons possuem origem eletrônica ou digital, no sentido de que não é necessária a correspondência às características acústicas e físicas do instrumento musical e a origem da produção do som, que pode ser oriundo de circuitos eletrônicos ou dados digitais que simulam, criam e transformam o som.

Ainda sobre os processos tecnológicos, o uso de meios digitais também propicia variabilidade de materiais ou ações que intercedem na produção sonora como, por exemplo, movimentos captados através de sensores que influenciam na produção sonora; ou sons captados que influem na apresentação de outras instâncias na intervenção, como projeção visual ou até mesmo em outros sons. Através do uso de meios digitais também se facilita que mais elementos sejam agregados, estabelecendo formas de participação.

Como discutido no capítulo anterior, maneiras de se trabalhar o som por interfaces reelaboram condições existentes entre escuta e produção sonora, o que pode ser aproveitado de maneira concordante com a proposta nas intervenções sonoras.

\footnotetext{
${ }^{3}$ Ondes maternot é um instrumento baseado em eletromagnetismo criado por Maurice Maternot e apresentado pela primeira vez em público em 1928. É um instrumento monofônico, que emite apenas uma nota por vez, e utiliza uma caixa de som para reproduzir o som gerado pelas válvulas de frequência oscilatória. O som se dá pela ação entre o anel do intérprete e o campo eletromagnético do instrumento.

${ }^{4}$ Theremin, ou eletrofone, é um instrumento criado por Leon Theremin patenteado em 1928. O funcionamento baseia-se em ondas eletromagnéticas e o instrumento possui duas antenas que controlam nota e intensidade de acordo com a proximidade das mãos do intérprete.
} 


\section{Engajamento através da escuta e participação}

A atuação de interfaces sonoras pode promover reflexões e interferir em dinâmicas e ações, devido a inter-relações que se dão entre som, entornos e pessoas. As pessoas também agem sobre esses elementos, não necessariamente sob a forma de atividade, como também participando através do próprio processo de escuta.

Sob essa perspectiva, há o paralelo entre a escuta passiva, que aponta mais para o ato contínuo de ouvir e sem atenção, e a escuta mais atenta e reflexiva, que vai além de seu sentido fisiológico, se faz de forma mais ativa e pode promover reflexões. O nível de engajamento do ouvinte durante atuação de uma interface sonora, contudo, não se dá apenas por suas atitudes e ações físicas na interface, mas também através de uma escuta mais internalizada, o que dificulta sua medição em processos acadêmicos de pesquisa.

A escuta coletiva confere uma abrangência além da individual já que, por não estar limitada aos fones de ouvido, pode agir em diferentes escalas do entorno sonoro. Dessa forma, estabelece o som como fator em comum às pessoas presentes em determinada porção de espaço físico, tornando-se fator em comum entre elas. Como será discutido posteriormente nesse capítulo, através do uso de formas de transmissão, tais como rádio ou internet, essa escuta pode referir-se a pessoas que estão em locais distintos, não existindo a necessidade de haver continuidade geográfica.

Voegelin (2010, p.27) reconhece que ouvir é uma tarefa subjetiva que demanda um engajamento com o trabalho sonoro. Sendo uma tarefa subjetiva, é maior a dificuldade na medição desses processos quando esses se referem à escuta internalizada. Além disso, os trabalhos não dispõem de informações referentes às reações do público.

As intervenções sonoras aqui abordadas, portanto, são interpretadas quanto à reação do público com auxílio de textos disponibilizados pela instituição ou artista, que muitas vezes se referem mais à intenção e leitura do próprio realizador, ou através de outros materiais, como, por exemplo, vídeos, associados à conceituação teórica da pesquisa. 


\section{Transformações quanto aos entornos sonoros}

Os entornos são modificados em sua totalidade quando combinados, constituindo entornos híbridos. Em relação ao som, a atuação de entornos sonoros através de interfaces implica também em uma justaposição ao entorno sonoro acústico, alterando a totalidade do entorno sonoro. Essas justaposições são complexificadas através do uso de interfaces, que são responsáveis por essas aberturas de possibilidades.

Não foi encontrado um estudo que fizesse referências diretas à constituição de entornos através de interfaces em intervenções sonoras. Portanto, recorre-se às investigações do âmbito da música, especificamente eletrônica e eletroacústica, pela preocupação desses campos disciplinares em estabelecerem relações dos espaços de performance e escuta.

Emmerson (2007, p. 97) considera que nosso universo sonoro existe em diferentes escalas. Através dessa consideração, o autor remete à aplicação da metáfora do enquadramento, delimitando áreas definidas de interesse e relacionando o espaço de performance com o som produzido. Apesar de Emmerson (2007) dedicar seu estudo à 64 música eletrônica e acusmática, podem ser realizadas derivações desses enquadramentos, devido sua pertinência à aplicação quanto ao espaço de performance e do ouvinte.

Abordando tais enquadramentos como espaços, Emmerson (2007) identifica escalas como local e campo (field), passíveis de interações entre si, e que também podem ser transcendidos, podendo caracterizar um radioframe, que se refere a um enquadramento que engloba todos os outros; um espaço virtual estabelecido por redes de comunicação como, por exemplo, a internet ou o rádio, que não obedecem necessariamente aos outros, promovendo características como descontinuidade geográfica e multilocalização entre os envolvidos. 


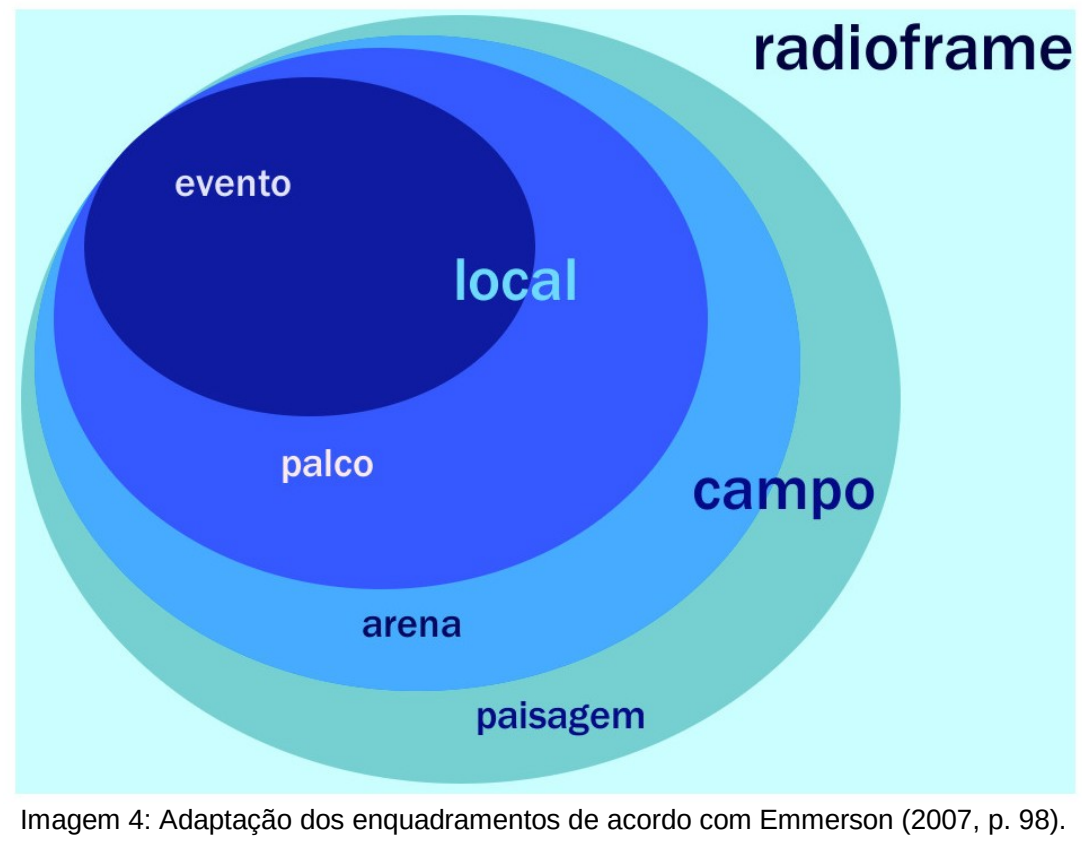

Dentro da escala do local, o som pode-se referir ao evento e ao palco, e no campo, arena e paisagem. Os controles referentes ao local procura estender a relação entre a ação do performer e do resultado sonoro. A função do campo está em criar um contexto, uma "paisagem ou ambiente onde a atividade do local pode ser encontrada"5 (EMMERSON, 2007, p. 92). O campo também possui agências que modificam o local, não sendo somente um 'campo reverberante'. O campo também pode ser transformado através de interfaces sonoras, de forma que a raiz do local se perca.

O local consta em uma escala em que controles e funções que procuram estender a relação percebida entre o performer e o resultado sonoro, enquanto que o campo cria contexto e meio onde a atividade local pode ser encontrada. Tem-se, portanto, uma relação acentuada desses enquadramentos quanto à produção sonora, pois, para Emmerson, a performance normalmente define tais espaços e suas relações inscritas. Emmerson (2007, p.97) também considera que "nas mãos de artistas esses

\footnotetext{
${ }^{5}$ Tradução nossa. "a landscape or an environment within which local activity may be found."
} 
enquadramentos tornam-se móveis, flexíveis e até mesmo sobrepostos" ${ }^{6}$. Ou seja, esses enquadramentos não são rígidos, dependendo das relações instauradas neles e sua produção.

Podem ser traçadas similaridades desses entornos mediados tecnologicamente com a sistematização e análise feitas por Smalley (2007). Trata-se de uma aproximação da análise da forma musical tendo o espaço como principal articulador, concentrando a abordagem na relação entre escuta e performance.

Smalley (2007) refere-se ao Performed Space ${ }^{7}$ como espaço de performance, a prática sonora intencional. O espaço de performance inscreve tanto o espaço dos gestos (gestural space) quanto os espaços produzidos pela atividade humana (agential space), abrangendo a voz ou a interação humana com objetos, superfícies e outros objetos físicos. Arena space é mais amplo que o espaço de performance, pois também inscreve o espaço habitado pelos ouvintes, que pode ser expandido através de mediações como o microfone e amplificador. No caso da reprodução, recorded arena space não estabelece vínculo direto com esse espaço de arena, como acontece em uma peça musical com instrumentos físicos, por exemplo. O recorded arena space é, de certo modo, "composto" pelo engenheiro/técnico de som. Mediatised performed space é mediado pela tecnologia, a fim de estender o contato visual, colaborando para a sensação de intimidade. Sendo mediado, se refere à transmissão dos espaços gestuais e do conjunto dos performers, onde há agência de microfones e amplificadores. É possível identificar nesses espaços determinados por Smalley (2007) três preocupações: as relações obtidas entre escuta, performance e a criação sonora, a abrangência desse espaço através de formas de mediação.

Nota-se, nessas duas análises, a relação principal entre performance e ouvinte, definindo performance, ou a produção sonora, como um ponto inicial para os outros espaços. No entanto, essas análises auxiliam entendimentos sobre constituição e justaposições de entornos sonoros.

Considera-se na presente pesquisa que o entorno sonoro acústico corresponde ao que se ouve sem o uso de equipamentos sonoros, esse entorno sonoro está restrito quanto à sua abrangência: está delimitado pela proximidade entre fonte sonora e ouvinte. Desde o

\footnotetext{
${ }^{6}$ Tradução nossa. "In the hands of artists these frames now become mobile, flexible, and even overlapping [...]."

${ }^{7}$ Por opção da autora, preferiu-se manter os termos na língua inglesa, original do artigo.
} 
advento de equipamentos sonoros, o som tem sido transmitido, armazenado, gravado, alterado, simulado, dentre outros processos que são recentemente intensificados por meios digitais. Assim, são formados entornos sonoros virtuais que podem ser transmitidos, que geram outras características quanto à sua abrangência. Transmissões são responsáveis por instaurar modos de abrangência mais abstratos, gerando também redes que se inter-relacionam.

Esses entornos sonoros, acústicos e virtuais, podem ser justapostos promovendo relações indissolúveis entre instâncias concretas e virtuais, resultando em diferentes configurações, estimuladas pelo uso de interfaces.

Considera-se que o som é um componente potencialmente representativo e que desfruta de inter-relações intensas com o espaço, portanto as interfaces sonoras não só colocam em contato o ouvinte com determinado som, como também podem gerar um locus onde pode estes ser postos em comunicação. 


\section{1 balançoires, Daily Tous Les Jours, 2011-2013}

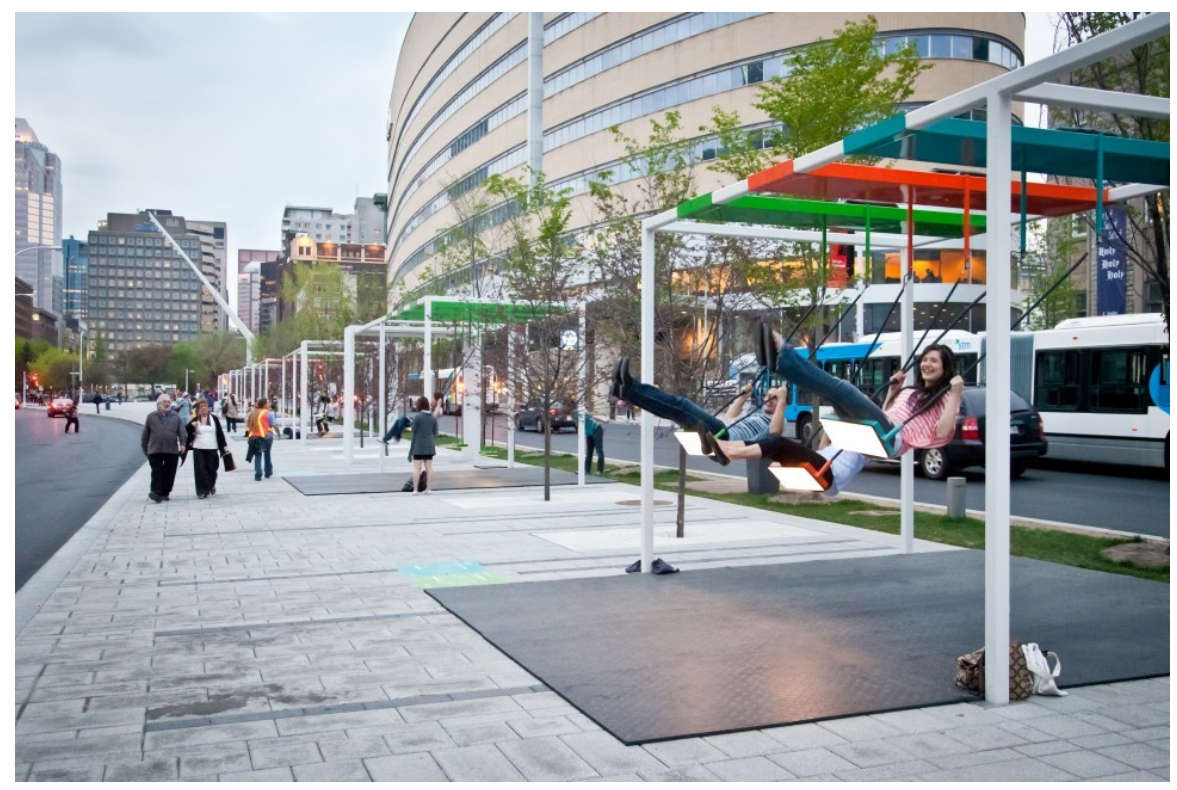

Imagem 5: 21 balançoires em Montreal.

Fonte: site do coletivo Daily Tous Les Jours. Fotógrafo: Olivier Blouan http://www.dailytouslesjours.com/project/21-balancoires/

21 balançoires, ou 21 swings, foi uma intervenção que consiste em 21 balanços que tocam sons de diferentes instrumentos em diferentes notas quando utilizados, realizada pelo coletivo de design Daily Tous Les Jours, de Montreal. Colocado em uma avenida, o grupo define 21 balançoires como um exercício de cooperação musical, pois, quando utilizado por vários participantes ao mesmo tempo, os balanços geram construções sonoras mais elaboradas do que quando utilizados por uma só. Segundo o site do grupo, "o resultado é um instrumento gigante coletivo que estimula apropriação do novo espaço, reunindo pessoas de todas as idades e origens, e criando um lugar para brincar e passear no meio do centro da cidade ${ }^{8, "}$ (DAILY TOUS LES JOURS, 2013).

De acordo com a matéria do jornal The Gazzete (HEINRICH, 2011), nove balanços emitiam sons de piano, seis de violão e outros seis de vibrafone. Quanto mais alto o usuário balançava, mais alta era a frequência da nota tocada. Segundo o mesmo jornal (Idem), os sons não possuíam forte intensidade sonora e tinham seu uso restringido até as

\footnotetext{
${ }^{8}$ Tradução nossa. "The result is a giant collective instrument that stimulates ownership of the new space, bringing together people of all ages and backgrounds, and creating a place for playing and hanging out in the middle of the city center".
} 
23h, o que denota preocupação em conter o entorno sonoro produzido em uma abrangência pequena e também não perturbar os arredores durante a noite.

\section{Direcionamento qualitativo dado pelas interfaces sonoras}

Sendo uma intervenção essencialmente interativa, 21 balançoires utiliza sons de instrumentos musicais tradicionais para despertar interesse nas pessoas para interagir. $O$ aspecto lúdico do ato de balançar colabora para atrair pessoas, e os sons produzidos pelos balanços colaboram, por sua vez, para convidar mais participantes para formar melodias musicais espontâneas.

As pessoas são atraídas a produzir sons em grupo, como em uma composição musical, através da interface pelo aspecto lúdico que a intervenção promove. Através do evidenciamento de que o resultado se torna mais rico a partir do momento em que os participantes negociam a altura que atingem com o balanço há o estímulo à produção sonora participativa, onde os participantes se comunicam entre si para obter melhores resultados.

Sendo originados por síntese sonora, os sons gerados não correspondem à configuração física dos balanços, o que acarreta em um distanciamento entre som produzido e fonte sonora. Enquanto nos instrumentos mecânicos tradicionais a produção sonora e seu objeto físico são inseparáveis, impondo limites às características sonoras, instrumentos digitais e eletrônicos possuem sua produção sonora independente da interface física acoplada, podendo reproduzir variados sons.

O som advém de caixas de som que não estão ao alcance da visão de forma óbvia, o que também muda a maneira como os balanços são percebidos, auxiliando a relação entre causa e consequência, ou seja, balanço e som musical.

Trata-se, por um lado, de um alargamento da noção de instrumento musical, possibilitando construção sonora conjunta, de maneira lúdica e despreocupada, no sentido de que torna desnecessário o conhecimento técnico e musical para interagir nos balanços. Por outro lado, é necessária a cooperação entre as pessoas participantes para atingir maior proveito 
da interface. Dessa maneira, o som reproduzido pela interface, promovendo a escuta coletiva, instaura algo em comum entre os participantes e observadores. Assim, o som reproduzido abre um campo para a participação coletiva e também para a negociação em busca de um objetivo em comum entre os participantes.

\section{Engajamento através da escuta e participação}

Pela sua localização, entre duas avenidas, a interface estimula o uso de um espaço físico que não é comumente utilizado. Não somente através das pessoas que participam utilizando os balanços, como também as pessoas que estão no local observando.

No caso de 21 balançoires, a produção sonora possibilitada pelo uso dos balanços convida, de maneira lúdica, as pessoas a utilizarem os balanços, bem como participar indiretamente da intervenção.

Os balanços constituem um local para o encontro, onde as pessoas se reúnem, participando da intervenção ou se reunindo em torno dela e, através da produção sonora e da cooperação entre os participantes que utilizam os balanços, aumenta-se o contato social entre as pessoas. Por não necessitar de conhecimentos específicos sobre música ou técnicas de instrumentos musicais, a interface abre oportunidades para a experimentação dos participantes. Dessa maneira o som musical, tem um efeito mediador ao estimular a construção de relações entre as pessoas.

A cooperação é o aspecto principal da intervenção: há o estímulo da interação entre pessoas que talvez não se conheçam, favorecendo um processo de busca coletiva de criar algo em comum. Segundo o coletivo,

A Cooperação surge quando o comportamento de cada indivíduo depende das decisões do resto do grupo: é um jogo onde, desde o começo, você precisa se ajustar às ações dos outros ${ }^{9}$. (DAILY TOUS JOURS, 2013)

\footnotetext{
9 Tradução nossa: "Cooperation emerges when the behavior of each individual depends on the decisions of the rest of the group: it's a game where, from the start, you need to adjust to the actions of others."
} 


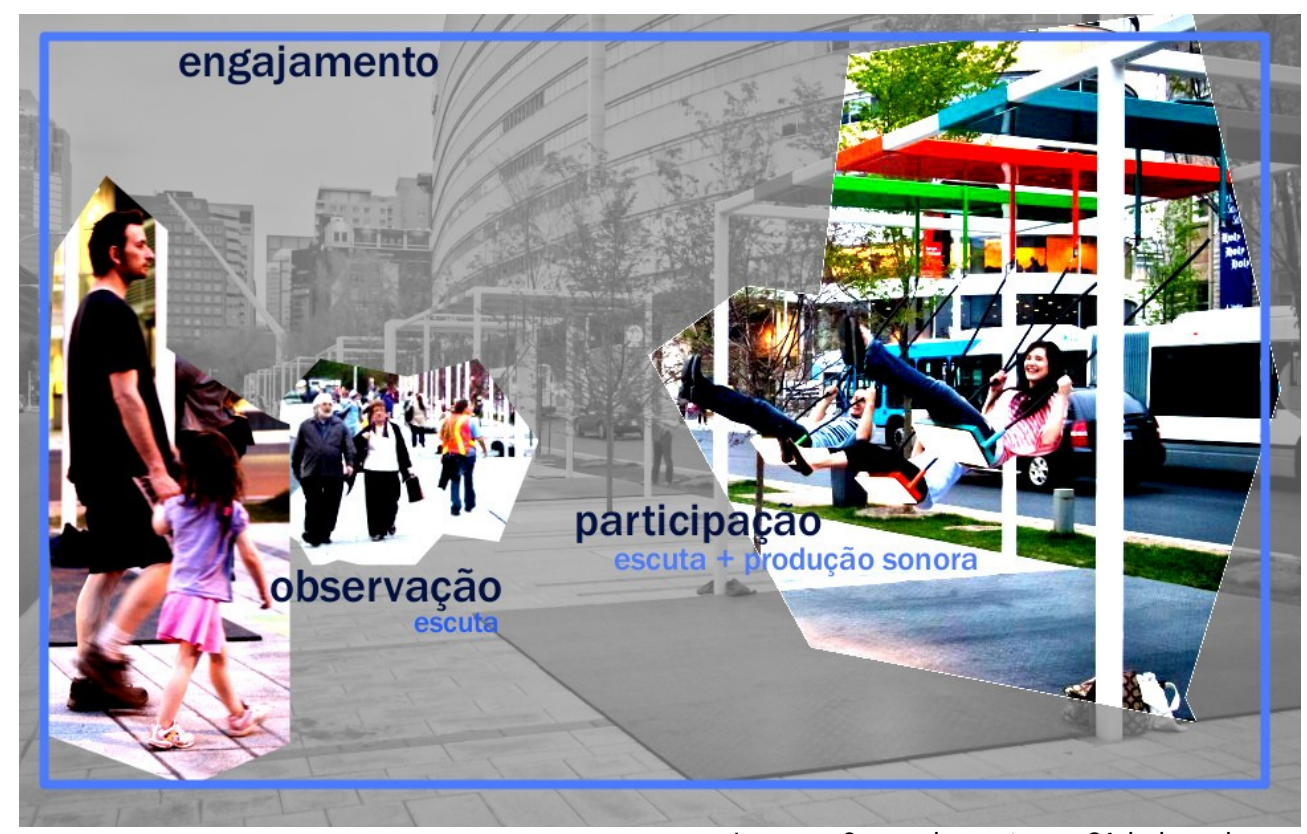

Imagem 6: engajamento em 21 balançoires.

Fonte: autora sobre fotos de Olivier Blouan, no site Daily Tous les Jours.

Dessa maneira a cooperação, aliada à escuta coletiva, possibilita completude à intervenção, levando-a a atingir seu potencial em maior nível. Em geral, para haver cooperação na construção musical é necessário não somente atuar e participar, como também ouvir os outros e a si mesmo. A intervenção, sob essa perspectiva, instaura um diálogo musical entre pessoas com o auxílio de interfaces sonoras, estimulando os participantes a ouvirem e perceberem as ações dos outros para tomarem decisões e participar da construção sonora.

Trata-se de uma forma de jogo sonoro, que reafirma a noção de improviso musical de David Hargreaves e Raymond MacDonald (2012): o improviso é essencialmente uma atividade social, espontânea, criativa e acessível. Social por reunir contribuições de mais de um indivíduo; espontânea por ser realizada enquanto se toca; criativa por gerar sempre resultados diferentes; e acessível por ser um processo em que todos podem participar, pois é uma atividade em que também são tomados aprendizados da vida diária. Ainda segundo Hargreaves e MacDonald (Idem), o improviso se trata de promover novas ideias em resposta a problemas e compartilhá-las em grupo. 
Sob desse ponto de vista, 21 balançoires é uma forma de improviso que possui tais qualidades, de maneira lúdica em que não são necessários conhecimentos musicais técnicos aprofundados para se produzir sons. A ativação dos sons de acordo com o uso do balanço pode retirar a sensação da obrigatoriedade de se ter um resultado detalhado musicalmente, favorecendo uma atitude mais exploratória. Dessa maneira, "a improvisação pode ser vista como um processo criativo exploratório para facilitar a expansão de horizontes pessoais ${ }^{10 "}$ (HARGREAVES, MACDONALD, 2012, p. 15).

A intervenção propicia um exercício de improviso musical, estimulando consciência dos usuários quanto à sua própria criação musical e também de ouvir, reconhecer o que é realizado pelas outras pessoas para ao mesmo tempo adaptar-se para construção de algo em comum.

\section{Transformações quanto aos entornos sonoros}

72 Em 21 balançoires a transformação do entorno sonoro se dá através da inserção de elementos sonoros sintetizados, que são controlados pelos participantes. O som, sintetizado e originado digitalmente, possui sua origem em instâncias virtuais, que compõe um entorno híbrido a partir da participação, que produzem os sons.

Sua ativação é diretamente relacionada com a participação das pessoas. Dessa forma, o ato de balançar, i.e., a interação insere elementos sonoros virtuais sobre o entorno sonoro e, por consequência, possibilitando outra forma de ação direta das pessoas sobre o entorno sonoro.

\footnotetext{
${ }^{10}$ Tradução nossa. "Improvisation in this sense is not about developing advanced music skills, but rather it is about borrowing from everyday life, and as such we all have the capacity to be musical improvisers."
} 


\section{Sound Island [Arche Sonore], Bill Fontana, 1994}

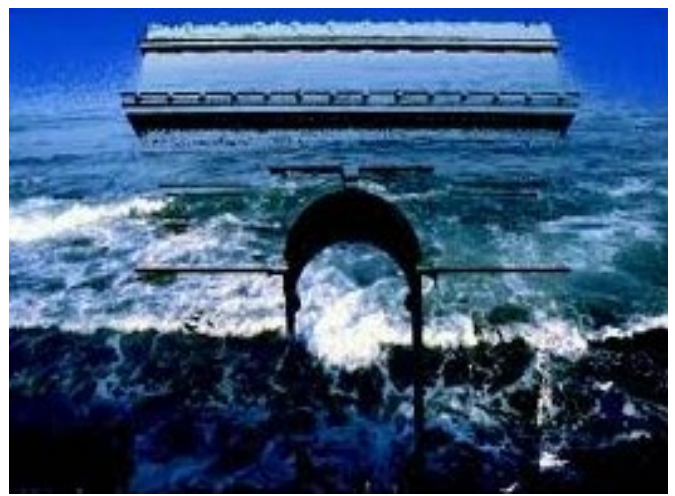

Imagem 7: representação de Sound Island.

Fonte: site de Bill Fontana.

Disponível em www.resoundings.org
Sound Island, ou Arche Sonore, foi realizada no Arco do Triunfo, em Paris, em homenagem aos 50 anos do "dia D" 11. A obra distribuiu-se em três locais diferentes onde eram reproduzidos sons de outras localidades.

Em dois acessos subterrâneos, foram instaladas caixas de som que reproduziam simultaneamente sons captados por hidrofones submersos nas águas da costa da Normandia.

Nas fachadas do Arco do Triunfo, Bill Fontana (ca. 1994) foram ocultados vários altofalantes, reproduzindo também simultaneamente o som do mar da Normandia. $\mathrm{Na}$ cobertura do Arco, havia a reprodução simultânea de sons de dezesseis locais diferentes de Paris, tratando da ideia de poder ouvir tão longe quanto o alcance da visão, criando um paralelo com o panorama visual que se tem do local, de onde partem 16 avenidas. A transmissão dos sons se deu através de sistema de radio transmissão, como é apontado por LaBelle (2006).

\section{Direcionamento qualitativo dado pelas interfaces sonoras}

Quanto à atuação das interfaces sonoras, é possível identificar nas três localidades de Sound Island o relocamento sonoro no pavimento subterrâneo e nas fachadas do Arco do Triunfo; e no terceiro andar a ampliação o processo de captação e de reprodução de som

${ }^{11}$ Dia D refere-se ao desembarque dos Aliados nas praias da Normandia, na França, um dos marcos do fim da Segunda Guerra Mundial e da vitória dos Aliados. 
procura prover maior alcance à escuta.

Trata-se de um relocamento sonoro pela reprodução de sons de outras localidades (RUDI, 2005; RESOUNDINGS, 2013). O som é captado e transposto a outra localidade simultaneamente, podendo adquirir outros significados de acordo com o contexto do local em que o som é reproduzido. Prefere-se o termo relocamento em detrimento ao de "deslocamento", pois se entende que esse termo confere um sentido negativo, de algo que está onde não deveria estar (EMMERSON, 2012). O termo relocamento faz transparecer que, através da transposição de sons de outra localidade, o som adquire outro contexto, sendo recontextualizado, transformando seu significado e não o perdendo.

Em entrevista concedida a Jøran Rudi (2005), Bill Fontana esclarece que seu trabalho de relocamento sonoro é parcialmente derivado da ideia de objet trouvé ${ }^{12}$ de Marcel Duchamp, que trata de objetos tidos geralmente como não-arte adquirirem o estatuto de peças artísticas a partir do contexto de onde são colocados; no caso de Duchamp, trata-se principalmente do museu e a galeria de arte. Tal prática pode se aproximar na música concreta, que se utiliza de sons gravados como recurso composicional: os músicos se apropriam de sons de variadas fontes sonoras, que podem ser caracterizadas como nãomusicais, para editá-las e compô-las como música, para então serem reproduzidas em concertos acusmáticos.

O cerne entre a questão do objet trouvé e Sound Island está em trocar o contexto de determinado som e considerar esse som captado, cotidiano, como merecedor de uma escuta mais atenta. O som é tratado como um objeto encontrado e apresentado fora de seu contexto, baseando-se na ideia de que a percepção e identificação visual dos espaços ensinam ao ouvinte o que se esperar sonoramente desse espaço (RESOUNDINGS, 2013).

No caso de Sound Island, sons cotidianos são captados, transmitidos e reproduzidos em outro contexto, sem edição. São sons comuns, que quando relocados em outro contexto podem gerar outras impressões do espaço. A captura do som em campo não se restringe apenas a um meio de investigação e, no caso de Sound Island, pode ser considerada como uma composição em tempo real: o som encontrado convida à escuta, obtendo valores diferentes quando relocado a outro contexto. Expectativas resultantes da percepção visual do espaço podem ser quebradas com o relocamento sonoro, e este pode consequentemente tornar-se mais notável por sua posição em outro contexto.

\footnotetext{
${ }^{12}$ Objeto encontrado. 
No pavimento térreo, onde está a praça, há sons do mar da Normandia, que é captado e veiculado para a praça via rádio. O som do mar é descontextualizado em relação ao espaço físico, além de também realizar um efeito de mascaramento [masque effet] (AUGOYARD; TORGUE, 2006): as frequências do som do mar se sobrepõem às frequências do tráfego local de veículos. Esse mascaramento se dá de modo favorável, pois se considera que "é possível evitar a percepção do rumor urbano no espaço da cidade" (AUGOYARD; TORGUE, 2006, p. 68). O relocamento providenciado pelos processos de captação, transmissão e reprodução em Sound Island também contribui para o caráter artístico da obra, realizando um paralelo do mar e das ondas ao movimento dos carros: pela sua localização, o Arco do Triunfo é uma ilha cercada pelo tráfego (RESOUNDINGS, 2013).

Nas passagens subterrâneas verifica-se também relocamento sonoro, onde há sons das águas da Normandia captadas por hidrofones, imersos na água. Segundo LaBelle (2010), há uma associação entre espaços subterrâneos e eco, bem como reverberação, devido às características desses espaços. Essa associação pode ser reafirmada em Sound Island, pois os túneis consistem em uma passagem subterrânea de acesso de pedestres da calçada ao Arco do Triunfo, com acústica propícia para reverberação e eco. A reprodução dos sons de água na passagem subterrânea reforça, portanto, a questão da recontextualização a partir da combinação entre som e espaço, realizando paralelos entre o submerso e o subterrâneo, o mar e o tráfego.

Na cobertura, o entorno sonoro tem sua abrangência aumentada: são reproduzidos sons de outros locais em Paris que são possíveis de serem vistos, mas não ouvidos. Ao mesmo tempo em que a visão alcança locais distantes, os sons desses locais são reproduzidos e trazidos à frente do ouvinte, gerando uma nova escuta. Assim, o Arco do Triunfo se caracteriza como um 'ponto convergente', onde os sons de variados locais de escuta se conectam, transformando o próprio entorno sonoro. Trata-se de uma confluência de variados sons, que são justapostos e que geram outro entorno sonoro que, aliado à visão, trata de contemplar a paisagem que abarcada pela visão de Paris de forma sonora. 


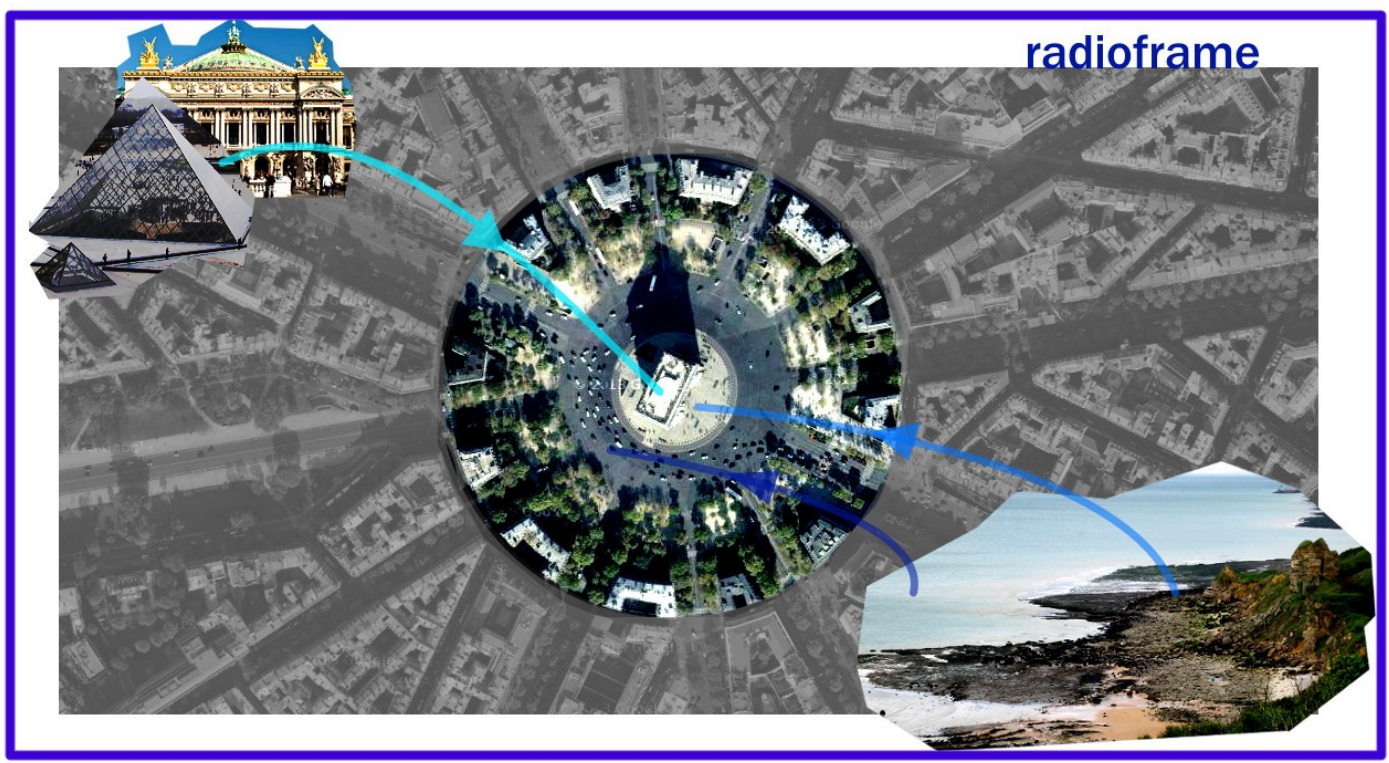

Imagem 8: diagrama representativo do live listening network, estabelecendo radioframe. Fonte: autora sobre imagens do GoogleEarth.

A transmissão via rádio, em tempo real, insere a ação de instâncias virtuais, que propiciam a interligação entre os locais. O Arco do Triunfo estabelece-se como um ponto convergente, uma rede que dá acesso à escuta de variados locais, formada pela transmissão. Trata-se, segundo Bill Fontana (RESOUNDINGS, 2013), na criação de redes de escuta ao vivo (live listening networks) que conectam múltiplos pontos sonoros em um ponto central de recepção.

\section{Engajamento através da escuta e participação}

O Arco do Triunfo é um dos locais mais visitados de Paris, recebendo um fluxo contínuo de turistas e também sendo um local em que há muito tráfego de veículos, que circulam em sua volta. A intervenção faz uso da escuta coletiva, o que também inclui várias pessoas no mesmo entorno sonoro híbrido que contrasta com os sons dos carros em volta do Arco.

Ainda que a intervenção sonora não possua aberturas para a participação do público, 
fornecendo a ele poder de influência sobre seu desenvolvimento, Bill Fontana (RUDI, 2005) defende que "[...] perceber, ouvir, experienciar e pensar são ações altamente participativas e interativas ${ }^{13}$.. Essa afirmação remete à escuta mais atenta e reflexiva, que não é simplesmente associada à imagem ou tida como efeito de uma causa ou objeto, como disserta o primeiro capítulo desta pesquisa.

Através da troca de contexto sonoro, Sound Island elabora relocamentos sonoros, nos quais o som adquire outro significado, e que também pode provocar estranhamento por sua troca de contexto. Essa ação assegura que a atenção do ouvinte se direcione ao som, pelo seu fator de estranhamento e novidade, iniciando assim outra prática de escuta mais reflexiva e atenta.

Pode-se perceber determinada aproximação com a escuta acusmática, ainda que o som não seja editado para adquirir outra forma. Não se vê a água do túnel, ou o mar, ou o teatro de ópera e o Louvre. Há um distanciamento da relação entre fonte sonora e som; o som não está subordinado à imagem, retirando a associação causal através da recontextualização, adquirindo outro significado através do entorno físico que o ouvinte se encontra. Essa troca de contexto altera o engajamento do ouvinte com o entorno sonoro.

Salomé Voegelin (2010) discute que é desse processo de se ter um engajamento mais profundo que gera um descobrimento através da escuta, que dirige ao conhecimento; contudo, é um processo individual e contingente. Essa afirmação relaciona-se com a ideia de Bill Fontana (RUDI, 2005) de que a quebra de expectativa, dada pela inserção de um som ao contexto do qual ele não pertence, transpassa a evasão natural de escuta das pessoas, portanto gerando outra forma de escuta. Dessa maneira, pode-se identificar que o uso de interfaces sonoras que utilizam o relocamento sonoro como uma forma de transpor a escuta cotidiana, pois o estranhamento e diferenciação dados pela quebra de contexto e identificação visual do espaço através do som resultam em um rompimento da escuta cotidiana. Também se pode identificar na intervenção que a escuta não está mais limitada geograficamente, nos três pavimentos, realizando uma quebra de continuidade geográfica.

\footnotetext{
${ }^{13}$ Tradução nossa. "[I think that] perception, listening, experiencing and thinking are highly interactive and participatory actions."
} 
Outro aspecto interessante é que a interface não trata do silenciamento do entorno sonoro acústico. Ao invés de promover um silenciamento para tornar o entorno sonoro com menor intensidade, Bill Fontana insere sons. O som do mar configura-se como um white noise natural, um som que possui densidade espectral equilibrada. Segundo o depoimento de Bill Fontana (ca. 1994), em vídeo disponível no site do artista (RESOUNDINGS, 2013), o som do mar mascarava o som do tráfego.

Quanto ao pavimento da cobertura, onde se ouve sons de diferentes locais de Paris, é possível estabelecer um paralelo entre panorama visual e sonoro, onde é possível ouvir tão longe quanto se pode ver. Através da transmissão do som, o ouvinte é posto em contato com diferentes sons que ocorrem simultaneamente em outros locais, ampliando a abrangência de escuta, podendo relacioná-la com a visão panorâmica.

\section{Transformações quanto aos entornos sonoros}

Sound Island trata de uma justaposição não somente entre som, contexto e localidade, como também uma justaposição de entornos sonoro e físico, além de agregar às suas instâncias virtuais formas de transmissão a rádio, complexificando a formação do entorno sonoro híbrido.

A transmissão possui papel essencial, criando uma rede invisível que conecta pontos de localidades diferentes, que então realiza a troca de contextos que dão origem à outra percepção do espaço. Através do relocamento sonoro simultâneo, Sound Island promove uma justaposição de entornos sonoros de localidades geograficamente distintas, a qual dá origem a outro entorno sonoro que influenciando a percepção do espaço, realizando transformações no contexto da localidade que recebe o som distante.

A transmissão auxilia o relocamento e a difusão, e também revela redes que possuem o som como seu resultado (LABELLE, 2010, p. 210). A transmissão simultânea amplia o entorno sonoro, deixando-o geograficamente descontínuo. Não é preciso estar no mesmo espaço-tempo que a fonte sonora para poder ouvir seu som, o que denota que meios tecnológicos nesse caso "aproximam lacunas, ao invés de criá-las ${ }^{14 " ~(E M M E R S O N, ~ 2012) . ~}$

\footnotetext{
${ }^{14}$ Tradução nossa. "[...] bridging gaps rather than creating them".
} 


\section{Tiefdruckgebiet, Carl Schilde e Anselm Nehls [Heavylistening], 2011-2012}

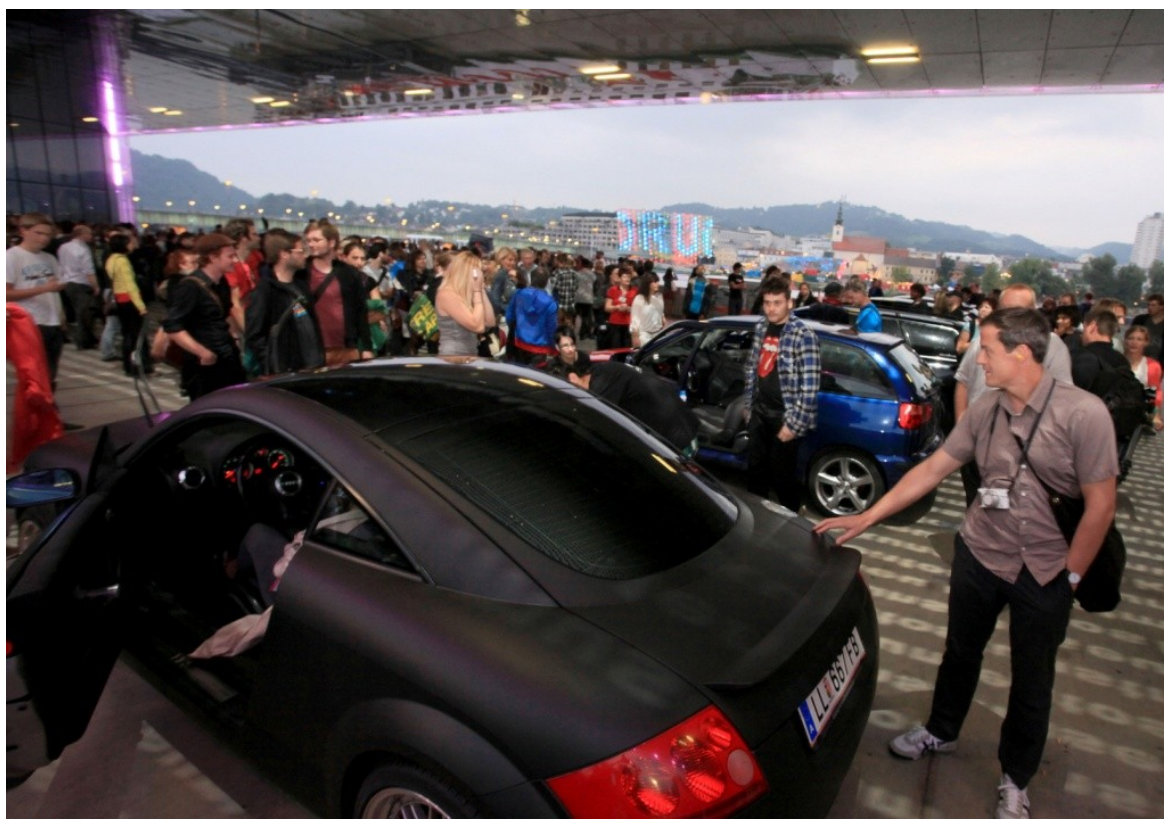

Imagem 9: Tiefdruckgebiet no Festival Ars Electronica em 2012. Fonte: site de fotos do Ars

Electronica. Disponível em http://www.flickr.com/photos/arselectronica/7920432850/in/photostream/

Tiefdruckgebiet significa "área de baixa pressão", em alemão. Realizada em variados locais, a intervenção se configura por aproximadamente 12 carros com equipamento de som potente o suficiente e hábil tecnicamente para reproduzir frequências muito baixas, às vezes inaudíveis. A intervenção foi disposta em áreas reverberantes ou ressonantes, onde o espaço físico absorve as frequências, audíveis ou inaudíveis; e por sua vez, o próprio espaço, afetado pelas ondas mecânicas, também produz som.

Competições entre donos de carros modificados para reproduzir frequências baixas com definição e intensidade são conhecidas popularmente por competições dB SPL [sound pressure level]. Contudo, nessa intervenção, os carros foram colocados em um contexto diferente: segundo os autores, eles "formam uma orquestra e criam, coletivamente, uma 
experiência de escuta física ${ }^{15 "}$ (HEAVYLISTENING, 2013a).

\section{Direcionamento qualitativo dado pelas interfaces sonoras}

O conjunto de carros em Tiefdruckgebiet se comporta como fonte sonora visível, não somente porque é possível perceber neles a origem do som, mas também porque os carros vibram fisicamente. Dessa forma, reproduzindo sons de frequências muito baixas às vezes impossíveis de serem ouvidas, Tiefdruckgebiet trata não só do som que é ouvido, mas também da experiência corpórea que essas frequências promovem: é também possível sentir de maneira háptica a ação das frequências.

A intensidade e frequências baixas escolhidas tornam perceptíveis as ações do som reproduzido sobre o espaço físico através de fenômenos acústicos, ou seja, torna notável a ação de ondas mecânicas, audíveis ou não, sobre elementos físicos. Sob essa perspectiva, a intervenção deixa claras as consequências sensíveis ao tato que o som pode conferir: é possível sentir a vibração das ondas mecânicas nos carros.

A intervenção instaura uma relação de dupla via entre som e espaço através de fenômenos físicos: não apenas as ondas mecânicas incitam reações no espaço físico, que se dão sob a forma de vibração, mas também o espaço físico influi no resultado sonoro através da reverberação.

\section{Engajamento através da escuta e participação}

Explorando frequências abaixo de $60 \mathrm{~Hz}$, o efeito dos carros não é apenas sonoro, mas também físico. Além dos carros vibrarem, é possível sentir efeitos dessas frequências também no corpo, derivando em uma experiência corpórea.

Um vídeo promocional, feito durante a realização da intervenção no Ars Electronica Festival 2012, em Linz, na Áustria (HEAVYLISTENING, 2013b), contém comentários do

${ }^{15}$ Tradução nossa. "... form an orchestra and collectively create a physical listening experience”. 
público sobre a intervenção. As pessoas entrevistadas no vídeo dizem poder sentir a mudança das frequências, até mesmo as que não foram ouvidas. Também comentam que, em certos momentos, não podiam escutar suas próprias vozes de forma apropriada. Algumas pessoas, tanto no vídeo quanto em imagens fotográficas (ARSELECTRONICA, 2013) tapam seus ouvidos, outras colocam as mãos nos carros para sentir a vibração e entram no veículo para sentir melhor as frequências através do corpo.

Do ponto de vista fisiológico, o corpo humano está sujeito a vários fenômenos de ressonância. No nível das frequências baixas, o corpo como um todo pode ser considerado como um grupo de subsistemas de massa-mola-amortecedor $^{16}$. (AUGOYARD; TORGUE, 2006, p. 106)

O corpo absorve, ressoa e reflete as frequências, respondendo às ondas mecânicas. Como diz um dos entrevistados no vídeo (HEAVYLISTENING, 2013b), "os protetores auditivos foram totalmente inúteis, porque você não escuta aquilo com seus ouvidos [...] Alguns órgãos internos estão de certo modo rearranjados agora, eu acho" 17. Dessa forma, pode-se afirmar que Tiefdruckgebiet torna o som fisicamente perceptível através da movimentação causada pela exposição às frequências graves. Contudo, vale lembrar que esses fenômenos podem provocar

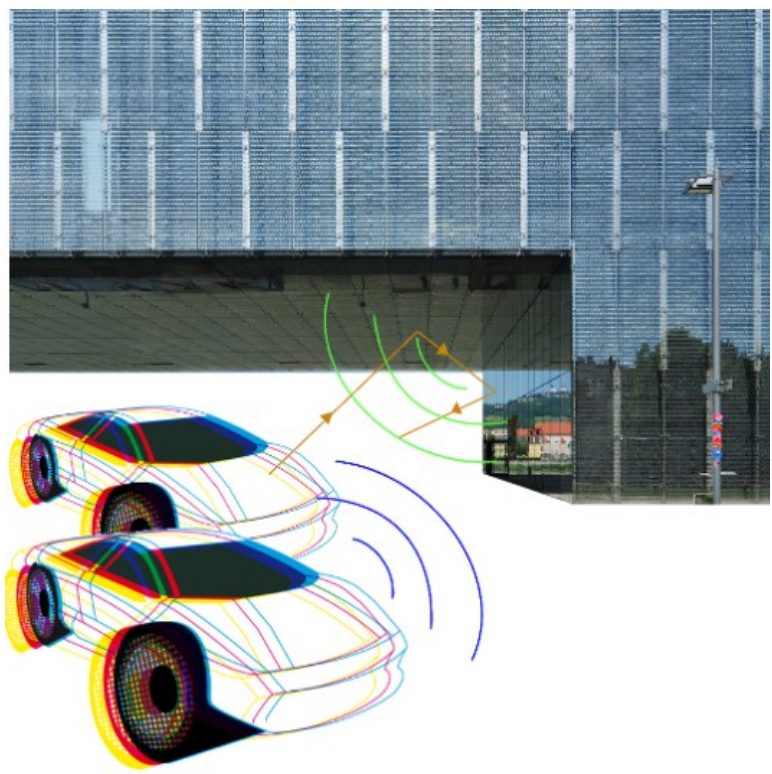
Imagem 10: Diagrama representativo dos fenômenos de ressonância, em verde e azul, e reverberação, em laranja. Fonte: autora. enjôos dependendo do

\footnotetext{
${ }^{16}$ Tradução nossa. "From the physiological point of view, the human body is subjected to many resonance phenomena. At the level of low frequencies, the body as a whole can be considered as a group of spring-mass-damper subsystems".

17 Tradução nossa, baseada na legenda em inglês: "The earplugs were really totally pointless cause you don't hear it with your ears anyway. [...] Some internal organs are somewhat rearranged now, I think."
} 
comprimento da onda, como apontam Augoyard e Torgue (2006, p. 107).

\section{Transformações quanto aos entornos sonoros}

Observa-se a atuação de dois fenômenos físicos que contribuem para a intervenção: ressonância e reverberação.

Ressonância acústica, grosso modo, é a absorção de energia por uma superfície, energia a qual é gerada por determinada frequência, o que ocasiona na vibração física da superfície (ROEDERER, 1998). No caso de Tiefdruckgebiet, as caixas de som reproduzem frequências baixas em alta intensidade, acarretando na vibração do próprio carro. Nessa escala, o carro comporta-se como um instrumento musical, aproveitando da ressonância de forma semelhante a um violão e outros instrumentos musicais. Nesse exemplo, as cordas são ativadas e produzem som, enquanto o violão ressoa conferindo características ao som através de um conjunto de frequências ressonantes.

82

Imaginando esse processo em uma escala maior, onde os sons dos carros também afetam o espaço físico provocando ressonância, devido à intensidade e às baixas frequências, trata-se de um processo em que o espaço físico é fortemente influenciado pelo som, ao mesmo tempo em que também influencia o som através da reverberação.

Como explicam Augoyard e Torgue (2006, p. 113), os elementos espaciais físicos determinam a reverberação de forma significativa também em função dos materiais utilizados. Trata-se, como foi dito, de uma relação de dupla via entre som e espaço físico dada pela energia e matéria física. Assim, intervenção trata da relação entre entornos sonoros e físicos através de fenômenos acústicos, demonstrando a relação conversacional entre esses elementos, onde um influencia o outro. 


\section{Voz Alta, Raphael Lozano-Hemmer, 2008}

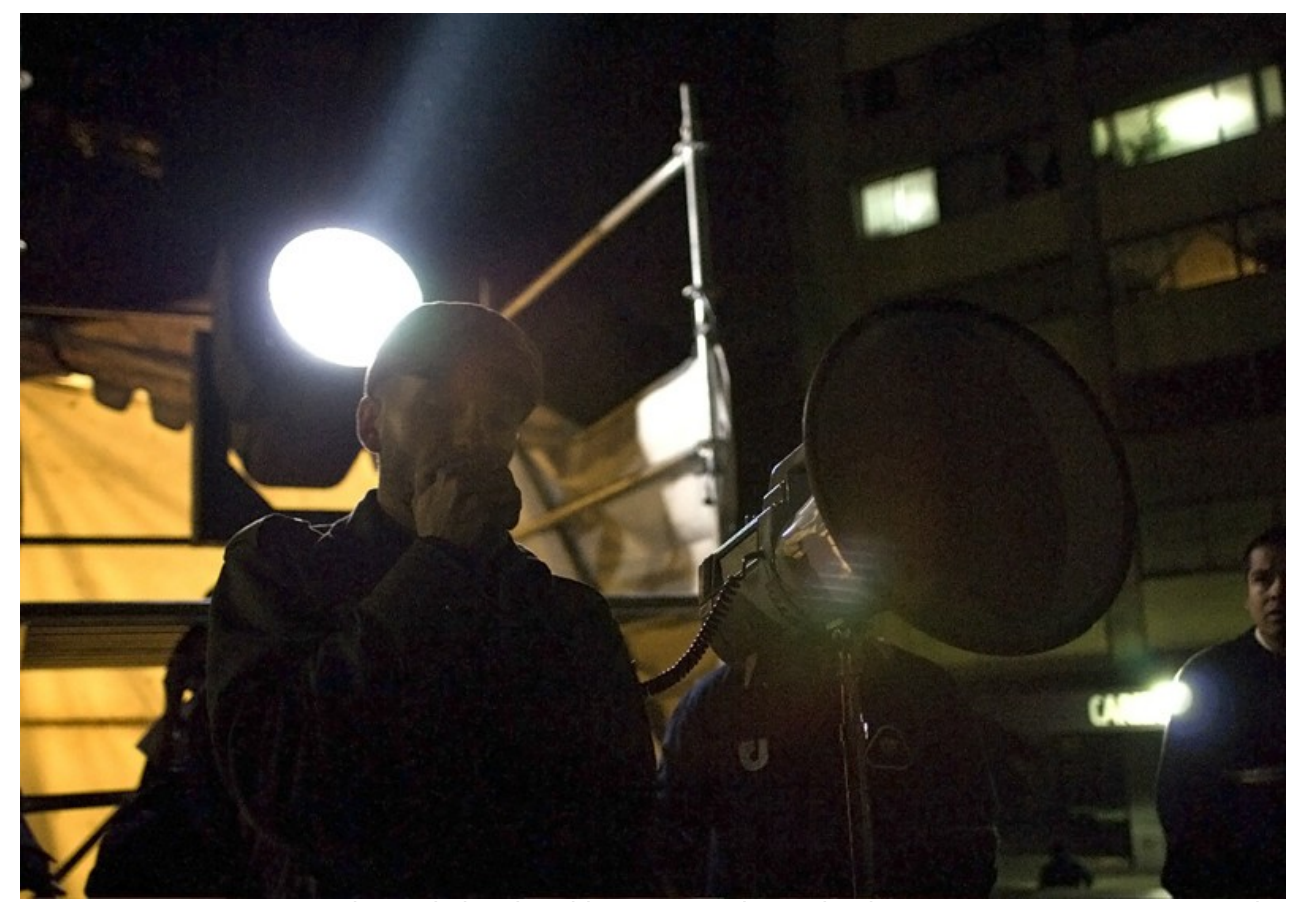

Imagem 11: "Voz Alta, Relational Architecture 15" de Raphael Lozano-Hemmer, 2008. Foto de Antimodular Research. Fonte: site de Lozano-Hemmer. Disponível em http://www.lozanohemmer.com/voz_alta.php

Em conjunto com a Universidad Autónoma del México, Raphael Lozano-Hemmer realizou essa intervenção como um memorial aos mortos no massacre de Tlateloco e ao movimento estudantil de 1968. Na Praça das Três Culturas, Cidade do México, um megafone modificado foi posto à disposição do público, que pode utilizá-lo para dizer o que quiser. As vozes são amplificadas pela própria ação do megafone, como também são veiculadas pela rádio da Universidad Autónoma Del México. Canhões de luz situados em variados locais na cidade foram acionados de acordo com as vozes, iluminando prédios de importância histórica. Quando o megafone não era utilizado, a estação de rádio transmitia reportagens, entrevistas e músicas relacionadas à época do massacre. 


\section{Direcionamento qualitativo dado pelas interfaces sonoras}

Lozano-Hemmer demonstra em suas obras como um todo o interesse de explorar os limites da arquitetura através diferentes interfaces, procurando fomentar outras percepções das pessoas que participam de suas intervenções sobre seu entorno, através da reavaliação de contextos (PONZINI, 2007). Em Voz Alta, a voz e o rádio têm papéis estruturais nessa reavaliação de contexto.

Segundo o site do artista (LOZANO-HEMMER, 2013), muitas pessoas participaram da intervenção, ouvindo ou participando através de comentários no megafone, que não teve censura ou moderação. Assim, os discursos apresentados no megafone pela população incluem tanto testemunhos de sobreviventes, gritos, poesia, propostas de matrimônio, convocações a protestos, dentre outros.

O megafone, através da amplificação que resulta em escuta coletiva, estende a abrangência da voz e estabelece a praça como um local de discussões. Trata-se de uma intervenção com abertura para a participação, no entanto que estimula reflexões para o participante fazer seu discurso. Por sua vez, o comentário estimula os outros participantes a refletirem sobre o assunto, formando um locus de comunicação.

Além de um objeto técnico, o megafone é uma interface que consolida a exposição pública, necessária para incitar um diálogo com interesses e valores compartilhados. É possível que a intervenção propicie a ligação do megafone a situações de protesto e inconformismo, ressaltando uma provável condição cultural e social dessa interface. As falas ditas no megafone, por sua vez, são estendidas à escala da cidade através da transmissão do rádio: esse aspecto dá acesso às pessoas presentes a difundirem suas ideias, canalizando o poder social para uma forma de comunicação em massa.

Lozano-Hemmer (ADRIAANSENS; BROUWER, 2002) determina seus trabalhos sob o escopo da arquitetura relacional, onde suas obras são intervenções efêmeras que procuram estabelecer relações arquitetônicas e sociais. Timothy Druckrey (2003) afirma que:

A interface é mais do que só um portal para uma ilusão; ela se posiciona contra ilusão a favor do desenvolvimento de uma relação única com o público distribuído sem perder a perspectiva de sua identidade e localidade, ou com os significados delicados de interatividade. [...] 
'escrever' o corpo dentro do 'texto social' do mundo físico, sugere colisões de significados que, por um lado, penetra esse trabalho em histórias específicas e, por outro, estende do confronto passivo do espaço para aquele do tempo (ambos históricos e experienciais) ${ }^{18}$

Para Druckrey (2003), a arquitetura relacional trata de evocar um espaço social no qual a participação é a força de criação de uma ágora dinâmica. Tais descrições se valem para Voz Alta, pois a praça possui um denso histórico de manifestações e de participação pública que é retomado através de interfaces sonoras. Através do som há uma construção comunicativa que se dá através de um canal aberto para contato com o outro através das interfaces, onde os participantes podem realizar comentários perante todos.

O rádio, por sua vez, expõe esse loci comunicativo fomentado na praça de maneira descontínua geograficamente. O papel do rádio em Voz Alta se aproxima da visão do dramaturgo Berthold Brecht (2007) exposta em texto originalmente escrito na década de 1930, que considera o rádio como um meio político com potencial democrático e interativo para a formação pública.

O rádio seria o mais admirável aparato de comunicação que se poderia conceber na vida pública, um enorme sistema de canais; quer dizer, seria, caso ele se propusesse não somente a emitir, mas também a receber; ou, não apenas deixar o ouvinte escutar, mas fazê-lo falar; e não isolá-lo, mas colocá-lo numa relação. O rádio deveria, portanto, sair da esfera do fornecimento e organizar o ouvinte como fornecedor. (BRECHT, 2007)

Para Brecht (2007), o ouvinte do rádio deveria ser produtor de conteúdo para assim promover "melhor emprego do aparato em razão do interesse público". Na intervenção, há essa subversão do caráter do rádio enquanto um aparato de distribuição, pois o público da praça tem acesso para expor suas ideias, sendo produtor de conteúdo, e também difundilas através da transmissão.

Sob esse escopo, as interfaces sonoras contribuem para reforçar o contexto histórico e político sobre o qual a intervenção age. Há oposição à repressão e censura,

\footnotetext{
${ }^{18}$ Tradução nossa. "the interface is more than Just a portal into na illusions; it stands against illusion in favour of developing a unique relationship with a distributed public without losing sight of either identity, locality or with the delicate meanings of interactivity. [...] to 'write the body' into the 'social text' of the physical world, suggests collisions of meaning that, on the one hand, embeds this work in specific histories, and, on the other, extendes from the passive confrontation of space into that of time (both historical and experiential)."
} 
providenciando formas de expressão que fomentam o discurso de assuntos públicos, que está presente tanto na praça quanto na cidade como um todo, através dos canhões de luz e da transmissão do rádio.

\section{Engajamento através da escuta e participação}

A participação e escuta se dão de maneira relacional. O megafone trata de estabelecer um canal para o participante propagar seus comentários e ideias, incentivando a reflexão através da fala e também se dispondo como um canal aberto para expor essas reflexões. Tanto o megafone quanto o rádio são interfaces que se relacionam profundamente com a fala e a propagação de ideias.

O papel do público é fundamental e impulsiona a realização da intervenção de tal forma que as interfaces somente tomam vida através do seu uso. Dessa maneira, percebe-se que a Voz Alta possui alto valor participativo, pois não é fechada em si.

Em outro aspecto, dado o contexto da praça, há também uma carga histórica do espaço físico e também da ocasião da homenagem aos mortos, o que auxilia a questão da memória ser abordada seja pela fala dos participantes ou pelas reflexões que podem originar dentro da intervenção.

A participação em Voz Alta, através de comentários relacionados ou não ao massacre ou à história, demonstram o que o autor chama de "memória alien" [alien memory]: alien é utilizada de maneira oposta à pretensão da palavra "nova (o)", denotando a algo que "não pertence", uma reposição, portanto referindo a reflexões que se dão de maneira diferente (PONZINI, 2007):

"memória alien" vem do desejo de olhar não à grande Memória (a memória com M maiúsculo) mas a esses pequenos comentários que podem surgir de micropolíticas, pessoas olhando para o trabalho, ou reclamando dele. É um nível muito íntimo, pequenos momentos significativos que mudam a forma que você se relacionaria com o lugar. ${ }^{19}$ (Ibid.)

\footnotetext{
${ }^{19}$ Tradução nossa: “'Alien memory' comes from the desire to look not at the big Memory (the capital M memory), but these small comments that may come up from micropolitcs, people looking at the work, 
Dessa maneira, Lozano-Hemmer deixa clara a relevância de pequenas ações ocorridas durante intervenções, direcionando a importância a esse âmbito micro. O artista denota assim a importância de uma transformação através de ponderações que podem ser trazidas pela intervenção.

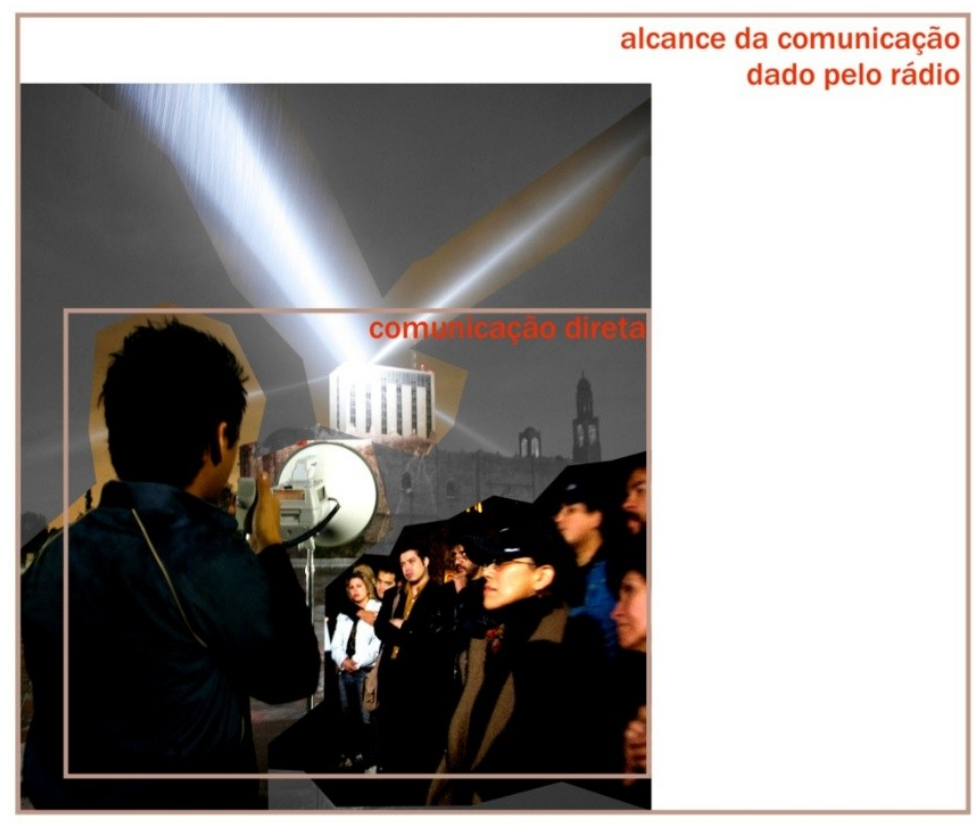

Imagem 12: comunicação em Voz Alta. Fonte: autora sobre fotos de Antimodular Research

\section{Transformações quanto aos entornos sonoros}

O rádio em Voz Alta, assim como em Sound Island, determina a abrangência do entorno sonoro de forma descontínua, porém realizando o processo inverso da intervenção de Bill Fontana. Enquanto Sound Island providencia um entorno sonoro que é convergente

or complaining about it. It's a very intimate level, little meaningful moments that make you change the way that you would relate to a place." 
através do rádio, aproximando o entorno sonoro de variadas localidades em um único ponto, no caso o Arco do Triunfo, Voz Alta amplia o espaço de atuação da voz que é localizada na praça, realizando uma difusão. Trata-se também de um radioframe e de uma rede de escuta ao vivo [live listening network], definida por Bill Fontana (RESOUNDINGS, 2013). A rede de escuta ao vivo em Voz Alta, por um lado, se difere da rede proposta por Bill Fontana em Sound Island, pois é de um ponto central (a fala do megafone) que se propaga a rede (quem sintoniza o rádio na estação); por outro, trata da questão de difusão da obra de maneira coerente com a sua proposta, pois subverte o papel do rádio, enquanto meio de comunicação bem estabelecido, possibilitando a difusão de ideias diversas que vêm do público, sem censura.

A intervenção instaura um local de reunião público, que não é contido no espaço físico, como também "no ar" através da transmissão, onde as discussões podem alcançar as casas de outras pessoas pelo rádio. O público da praça como participante, portanto, faz parte de um locus comunicativo que se estende a variadas outras localidades.

Na praça, através da participação junto com a ação do rádio, os limites entre público e participante, performer e ouvinte, são embaraçados diante do acesso à interface e também através das pequenas ações que ocorrem em torno dela. Assim, observa-se a formação de entornos híbridos, que são difundidos através de interfaces que promovem empoderamento à fala pública e às discussões.

\section{Sons do invisível}

Como exposto na introdução desse capítulo, há um amplo campo de intervenções em espaços públicos que utilizam interfaces e que realizam abordagem das relações entre som e espaço de maneiras muito diferenciadas. Através da seleção das intervenções para as leituras pode-se perceber, por um lado, a especificidade de suas abordagens e objetivos, e, por outro, correlações que podem ser feitas entre as intervenções.

A concepção dessas intervenções se dá sob o escopo de variadas áreas, do design à arte sonora e à arte performativa. Dentro de um panorama geral, é possível perceber que essas práticas misturam em si variadas temáticas. Intervenções sonoras possuem um elevado potencial multidisciplinar, além de serem formas de criar condições não só para 
outras formas de escuta, mas também levantando discussões, reflexões, formas de expressão, de participação e socialização com o outro, transformando dinâmicas dadas em determinado espaço, ocupação de espaços públicos no cotidiano. Além disso, é notável a importância do entorno sonoro junto ao espaço, bem como a ação recíproca existente nesses dois elementos.

As intervenções também demarcam transformações que são dadas pelas Tecnologias de Informação e Comunicação. No presente capítulo há o exemplo do rádio, utilizado em Voz Alta e Sound Island, que trata de estabelecer uma rede invisível de conexões que amplia abrangência entornos sonoros, auxiliando o adensamento do espaço arquitetônico e, por sua vez, estabelecendo relações intrínsecas entre instâncias virtuais e físicas.

É possível perceber a integração entre as propostas das intervenções ao uso de interfaces sonoras. Cada tipo de interface sonora facilita o direcionamento da intervenção rumo aos objetivos delineados em sua concepção.

As intervenções tratam, fundamentalmente, de alterar ordens pré-estabelecidas nas dinâmicas do espaço, e ao mesmo tempo as consideram, resultando em uma relação conversacional. Por essas leituras também é possível concluir que variados conceitos teóricos estão inscritos nas práticas, que se aproveitam das relações entre som e espaço de forma qualitativa para sua concepção, onde as interfaces desempenham papel estruturante na abordagem das intervenções. 


\section{Experimento:}

\section{outros sons, mesmo espaço?}

O experimento realizado na presente pesquisa é fruto de reflexões de estudos teóricos e também da compreensão de outras experiências com interfaces sonoras já realizadas. Assim, o experimento complementa de maneira fundamental os interesses da pesquisa, ou seja, fornecer aporte prático ao teórico. Seu objetivo é investigar combinações de entornos sonoro e físico e promover essas combinações através da utilização de uma interface que promova a escuta coletiva, explorando relações entre som e espaço sob a forma de intervenção. No contexto da pesquisa, o experimento possui uma dupla intenção: verificar questões abordadas pelo estudo teórico e produzir insumos para outras reflexões, dessa forma realimentando o estudo teórico. A contribuição do experimento à pesquisa tem o mérito de não só auxiliar compreensões acerca dos conceitos, através da formação de relações teóricas, como também levantar outras reflexões referentes à metodologia e ao próprio processo de pesquisa.

O experimento foi realizado em três etapas, as quais serão descritas detalhadamente neste capítulo: a primeira que se refere à concepção de uma intervenção sonora e investigação sobre os entornos sonoros dos locais abordados pela intervenção, com coleta de áudio e vídeo nos locais, praça do Mercado Municipal e o Conjunto Habitacional Waldomiro Lobbe Sobrinho, ambos na cidade de São Carlos, Estado de São Paulo; a segunda, atuação da interface sonora, ou seja, a intervenção propriamente dita amparada por determinados procedimentos metodológicos que serão descritos neste capítulo; e a terceira, análise do material coletado, que implica na elaboração de relações entre prática e conceitos teóricos.

O experimento utiliza-se de procedimentos metodológicos alternativos aos métodos mais comumente utilizados no meio acadêmico e tem como proposta aumentar seu alcance e a proporcionar diversidade de pessoas envolvidas, além de se configurar como uma alternativa para reconhecer participantes da intervenção como produtores de reflexões e criadores de conhecimento. Para tanto, dentre as etapas do experimento, alia-se a atuação da interface sob a forma de intervenção. 
A primeira etapa do experimento consta primeiramente em discussões entre pesquisadores do Nomads.usp para a concepção da intervenção, contemplando conceitos levantados pela pesquisa e também o contexto da cidade de São Carlos. Foi definido que o caráter da intervenção se estruturaria sobre a gravação de sons do trem no Conjunto Habitacional, cuja ferrovia também atravessa a cidade, para a reproduzi-los na praça do Mercado, configurando um relocamento sonoro. Assim, determinou-se a realização de coleta de áudio e vídeo sob o método soundwalk, descrito nesse capítulo, a fim de construir maiores entendimentos sobre os entornos sonoros dos dois locais.

A intervenção, ocorrida na segunda etapa, teve como métodos registros em fotos e vídeos e entrevistas semi-estruturadas, gravadas em consenso com os entrevistados para posterior análise. A intervenção, assim como trabalhos sonoros referidos no capítulo 2 , configura-se como uma mudança intencional sobre um contexto sonoro prévio, consequentemente das dinâmicas espaciais, oferecendo uma situação na qual se pode fomentar o surgimento de outros modos de sensibilização das pessoas, também de maneira interior e individual, quanto ao seu próprio contexto, espaço e entorno sonoro.

Inspirada por conceitos como relocamento sonoro, explorado por artistas como o americano Bill Fontana (RESOUNDINGS, 2013), a estrutura da intervenção se dá na transposição dos sons emitidos pelo trem quando ele perpassa o Conjunto Habitacional, o $\mathrm{CDHU}^{1}$, para a praça do Mercado Municipal de São Carlos, onde o som do trem é normalmente pouco audível e, mesmo assim, longinquamente e ocasionalmente. Os sons do trem, previamente coletados no CDHU, são reproduzidos na praça do Mercado.

O trem passa pela ferrovia próxima ao $\mathrm{CDHU}$ várias vezes por dia, inclusive à noite, em intervalos de aproximadamente duas horas, às vezes em intervalos de tempo menores. $O$ trem pode ser ouvido em vários bairros da cidade, porém tendo como base o estudo teórico admitiu-se, para a concepção da intervenção, que o conjunto de elementos sonoros do trem possuiria significados diferentes entre as pessoas; inclusive entre a população do CDHU e as pessoas que se utilizam da Praça do Mercado.

Para maior entendimento dos conceitos estudados, a intervenção tem o intuito de estimular diferentes percepções da praça do Mercado Municipal de São Carlos através da

\footnotetext{
${ }^{1}$ O Conjunto Habitacional Waldomiro Lobbe Sobrinho é popularmente chamado de CDHU, e será referenciado dessa forma na presente dissertação.
} 
justaposição de entornos sonoros, colocando a população do local em contato com o efeito do trem e da ferrovia na cidade, bem como no CDHU. A intervenção, de caráter exploratório, visou a utilização de interface sonora de forma que dialogasse com características dos locais do experimento: portanto foram realizadas referências ao contexto histórico e físico-territorial da cidade de São Carlos em relação à ferrovia e, mais especificamente, do CDHU. Abordar um conjunto de sons que se apresentam de maneira característica no entorno sonoro do $\mathrm{CDHU}$ confere à intervenção um caráter político: tratase de relocar não somente o conjunto sonoro, mas também o contexto de um bairro periférico para uma área central e comercial da cidade.

De acordo com Patricia Leavy (2009), práticas como a intervenção sonora proposta auxiliam o alcance da pesquisa a um público maior e mais diverso, facilitando a aproximação dos pesquisadores à pessoas de populações diferentes. Observou-se que a intervenção facilitou o acesso dos pesquisadores às pessoas que estavam na praça, realizando entrevistas com pessoas que estavam na praça ou que apenas estavam de passagem. Como resultado disso, obteve-se um espectro amplo de qualidades de respostas às entrevistas, que abrangeu pessoas de diversas faixas etárias e que moram em diferentes locais da cidade. Desse modo, a intervenção propiciou uma situação que não só se apresentou como uma forma diferenciada de se obter respostas de diferentes entrevistados, sendo possível identificar nuances em alguns discursos, como também propôs reflexões ao público.

Como exposto na introdução da presente dissertação, a concepção e elaboração do experimento provêm também de outras práticas inscritas no Nomads.usp desenvolvidas no Projeto de Políticas Públicas "Territórios Híbridos: meios digitais, comunidades e ações culturais", consideradas ações culturais. As ações, como um todo, procuraram fomentar construções coletivas do espaço público auxiliadas pelo uso de meios digitais, estabelecendo esferas de comunicação que convidavam à expressão e à coexistência de olhares distintos (NOMADS.USP, 2013). De forma direta, o experimento prático foi beneficiado pelas ações promovidas no $\mathrm{CDHU}$, que auxiliaram na aproximação da pesquisadora ao contexto da população; e também a ação Captas ${ }^{2}$.

\footnotetext{
2 Captas é uma intervenção concebida por Fábio FON e Soraya Braz, que performers se utilizam de capas amarelas com caixas de som nos cotovelos, que disparavam conversas telefônicas prégravadas quando encontravam pessoas falando ao celular, pois as capas possuem sensores que 
No projeto Territórios Híbridos, a ação Captas ocorreu na Praça do Mercado e contou com a participação de estudantes de teatro como performers. Para a realização dessa ação foi necessário compreender o entorno sonoro da região da Praça do Mercado, bem como entender suas dinâmicas sociais.

Além da ação Captas, o Territórios Híbridos promoveu também outras ações culturais no CDHU, que possuíam variadas formas de expressão por meios digitais. Foram ações que possibilitaram aproximação dos pesquisadores ao contexto dos habitantes do conjunto, sob a premissa de transformar o público de ações culturais em participantes. As ações envolveram graffiti, graffiti digital, vídeo, contato com moradores de Cidade Tiradentes ${ }^{3}$, dentre outras.

\section{Três elementos em “Reverberação Urbana”}

A intervenção "Reverberação Urbana", peça central do experimento realizado, constitui uma maneira para compreender a aplicação prática de conceitos apresentados durante essa dissertação, integrando prática e investigação teórica para formular análises, reflexões e conclusões. A intervenção foi uma prática proveitosa para se reavaliar conceitos previamente estudados, propor co-relações entre eles inserindo outras questões à pesquisa, além do auxílio à compreensão que a prática oferece.

"Reverberação Urbana" foi constituída através de discussões entre pesquisadores do Nomads.usp, cujos estudos também possuem experimentos, além de ter tido sua concepção também auxiliada pelos conceitos teóricos.

O trem e a ferrovia fazem parte do contexto histórico, econômico e social de São Carlos, porém seu uso atual é apenas de transporte de carga. Quando a linha férrea foi implantada, na virada do século XIX e XX, trechos urbanos foram reorganizados em

conseguem captar ondas eletromagnéticas que se dão com o uso de celulares (NUNES; BRAZ, 2011).

${ }_{3}^{3}$ Bairro periférico da zona leste de São Paulo, capital do Estado, onde há vários conjuntos habitacionais. 
função de seu trajeto. Ou seja, é secular o impacto do trem sobre São Carlos. O que mudou ao longo do tempo foi o significado que o trem tem para a cidade e seus moradores.

A ferrovia atravessa vários bairros da cidade, tanto de dia quanto à noite, e os sons promovidos pelo trem são de alta intensidade: buzinas, locomotivas, vagões nos trilhos, freios. O trem não está apenas sonoramente presente em seu trajeto; existem cruzamentos nos mesmos níveis das ruas, impondo seu ritmo ao tráfego de veículos e de pessoas, e a ferrovia possui proximidade de áreas residenciais cujas construções podem vibrar com a passagem do trem. No CDHU, o trem se faz presente nesses três aspectos: a proximidade dos condomínios e apartamentos à linha; cruzamento férreo na rua e o som, que se propaga por todo conjunto e por vezes promove consequências físicas devido à sua intensidade por meio de ressonância.

Imagem 13: Área centro-sul de São Carlos, com ponto vermelho indicando a localização do CDHU em São Carlos e ponto amarelo indicando a localização da Praça do Mercado. Fonte: Nomads.usp, imagem de satélite do Googlemaps.

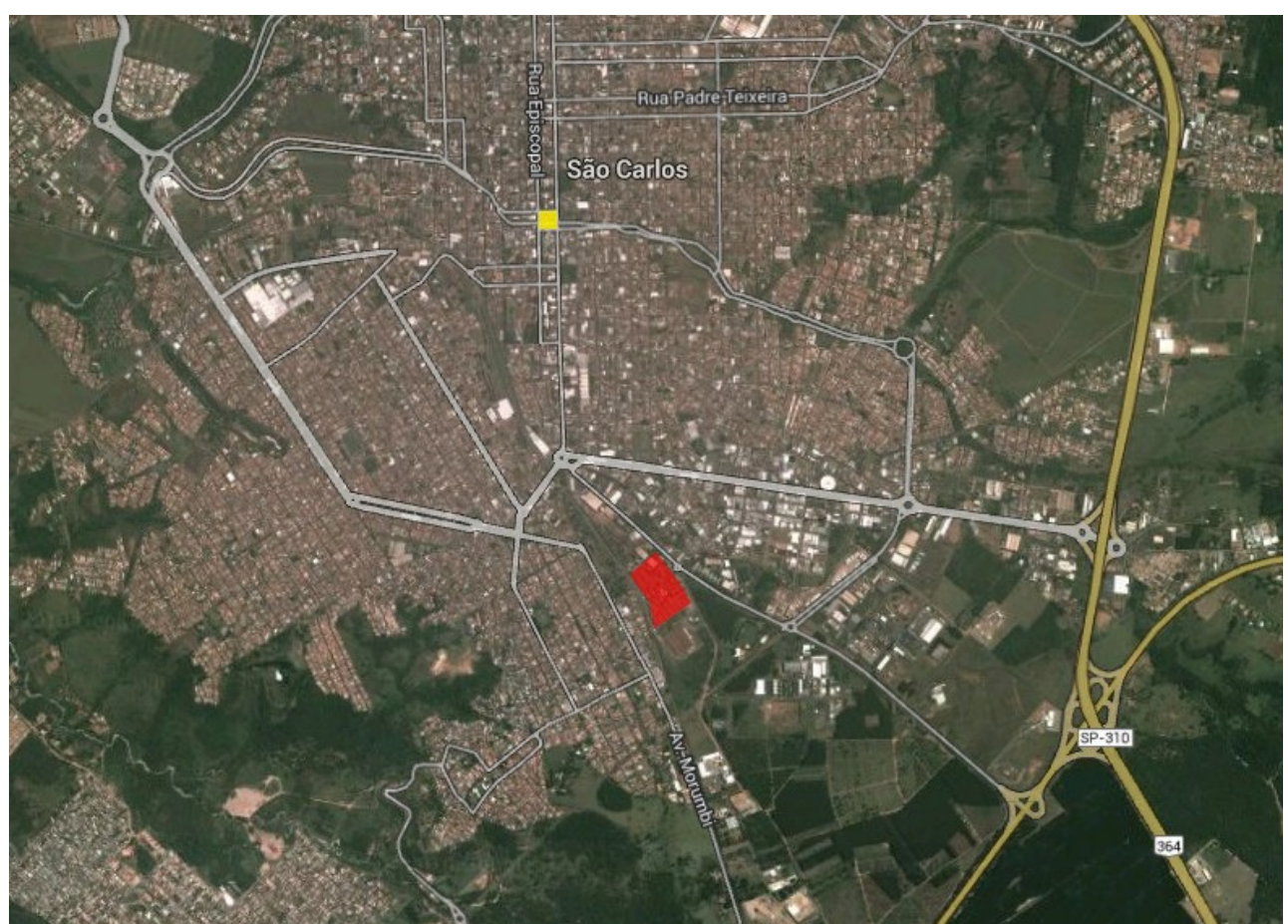

escolheram-se os sons propagados pelo trem em movimento quando ele passa pelo 
CDHU, como elemento a ser trabalhado na intervenção. Para tanto, os sons do trem são relocados à Praça do Mercado, no centro da cidade.

Teve-se também a intenção de reproduzir os sons de trem de forma intensa e distribuída em dois canais para dar a sugestão de que o trem estaria passando pela praça. Como a praça nunca foi atravessada pela linha férrea, os sons relocados na Praça do Mercado possuem falta de contexto não só referente ao local atual, como também histórico. A história da cidade de São Carlos tem a ferrovia como um fator importante, no entanto não existe mais o contexto que ferrovia teve no passado, como será discutido brevemente a seguir.

É possível observar três elementos, portanto, que compõem a intervenção: o CDHU e a Praça do Mercado, ambos com suas dinamicidades espaciais; e os sons do trem e, por fim, a ferrovia. O CDHU situa-se na periferia sul de São Carlos e foi construído no escopo do programa "Sonho Meu", destinado à população de baixa renda; possui 928 apartamentos divididos em 6 condomínios que são dispostos independentemente, onde cada condomínio possui 5 blocos, com exceção do condomínio 01 que possui 4 blocos (MIYASAKA; ANITELLI; PRADO, 2009; DIAS, 2013).

No âmbito do projeto Territórios Híbridos, através de ações no CDHU, alguns moradores citaram informalmente o "barulho" como um problema por alguns moradores: muitas vezes oriundo do trem, outras vezes dos vizinhos e, também, da rua. O contexto do CDHU foi escolhido também por se tratar de um bairro abordado pelo Projeto de Políticas Públicas "Territórios Híbridos", e pode ser considerado um bairro que é marginalizado socialmente em relação a alguns moradores da cidade. Dessa forma, é favorecido um caráter político e social por colocar a população que utiliza a Praça do Mercado em contato com questões desse Conjunto Habitacional. 


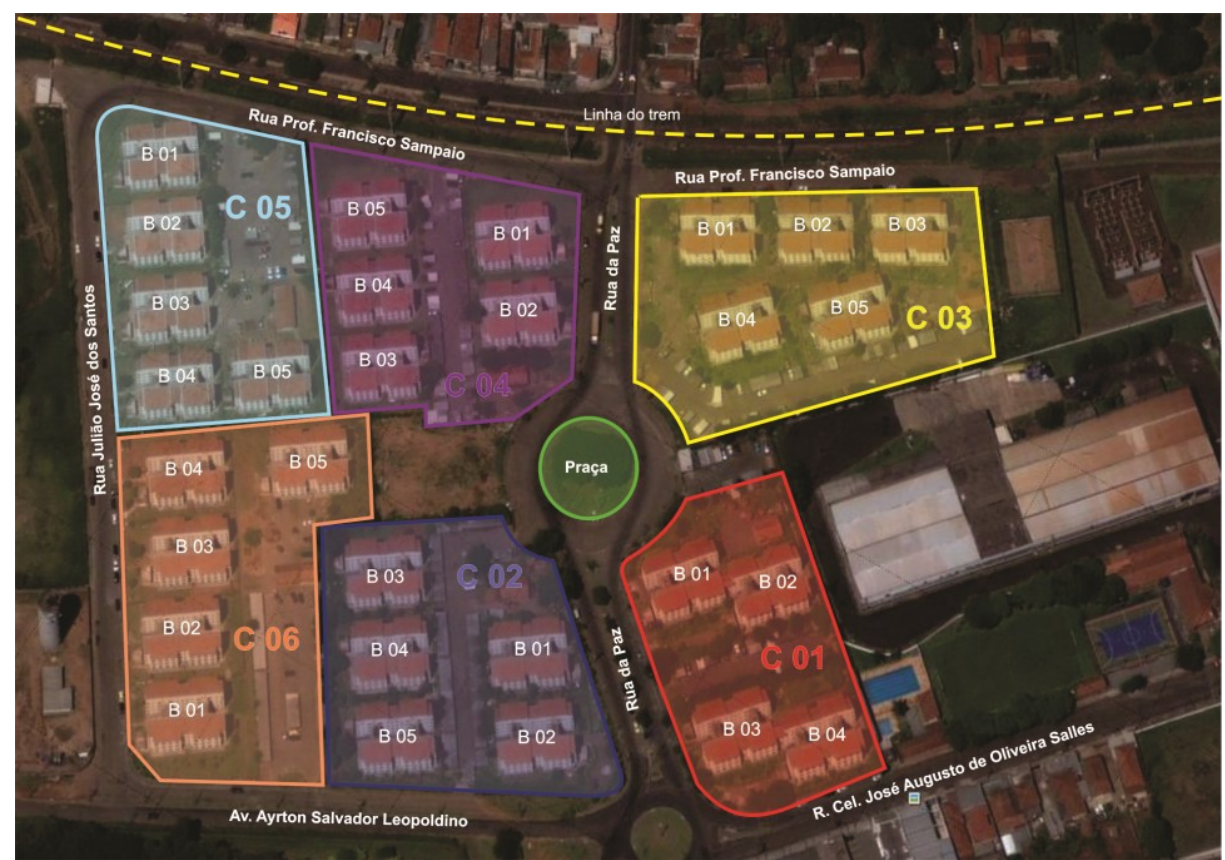

Imagem 14: o CDHU, dividido em condomínios e blocos.

Fonte: Nomads.usp, imagem de satélite do Googlemaps.

A Praça do Mercado está no centro comercial da cidade e dispõe de alta intensidade de tráfego de veículos nas ruas ao seu redor, especialmente durante o horário comercial. Pelo seu caráter de área comercial, também por ser próxima a uma das principais avenidas da cidade e possuir pontos de ônibus nos arredores, a praça é utilizada durante o horário comercial por pessoas de diferentes bairros da cidade. Supôs-se a utilização da praça por diversos grupos sociais, presentes diariamente, o que foi um fator que contribuiu para a escolha da praça como local da intervenção, pois essa diversidade enriqueceria os resultados. A ferrovia na cidade de São Carlos, atualmente, está sob gestão da América Latina Logística, ALL, com contrato previsto até 2028. A linha de São Carlos está incluída no trajeto ferroviário que conecta a Baixada Santista às cidades paulistas de Santa Fé do Sul e Colômbia, que possuem conexões a outros Estados (ALL-LOGISTICA, 2013). Portanto, o trajeto da ferrovia auxilia o escoamento de produtos para a região CentroOeste e, no sentido inverso, da produção agrária para o Porto de Santos. Com essas características, a ferrovia serve mais interesses regionais, de integração comercial de Estados brasileiros, do que interesses específicos da população de São Carlos. 


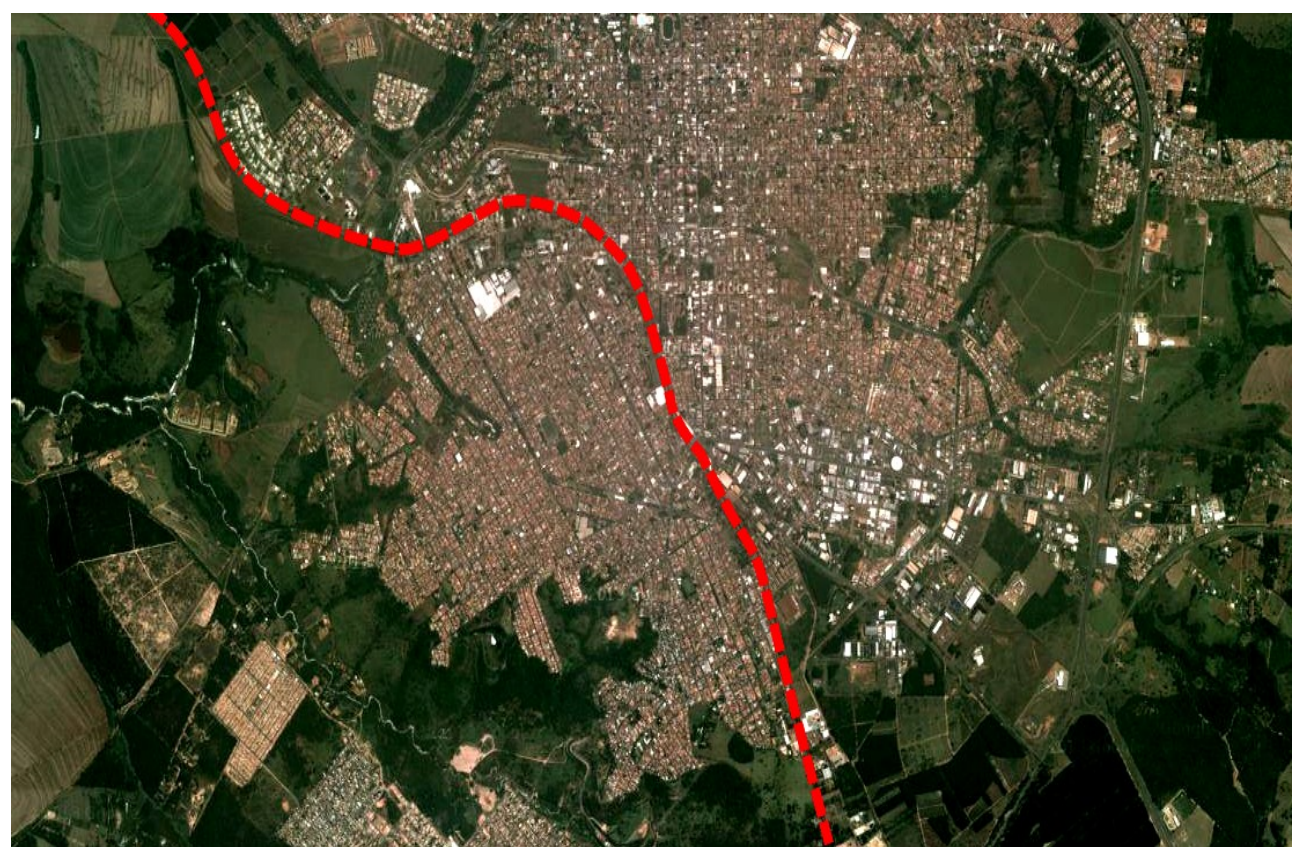

Imagem 15: área centro-sul de São Carlos, com tracejado indicando o trajeto da ferrovia.

Fonte: autora, imagem de satélite do Googlemaps.

A inauguração da ferrovia em São Carlos se deu em 1884, principalmente para satisfazer necessidades da oligarquia local, dedicada majoritariamente à cultura cafeeira (TRUZZI, 2000). A ferrovia historicamente é um marco tanto por se configurar como uma via de acesso, quanto por transportar variados produtos. Fornecendo suporte à economia cafeeira, ela também contribuiu para desenvolvimento da economia urbana, tanto direta como indiretamente: os fazendeiros mais bem sucedidos, de acordo com interesses econômicos implícitos, investiram em melhoramentos em redes de transporte, bonde, pavimentação, telefonia, construção de edificações, dentre outros (LIMA, 2007).

A ferrovia também direcionou a concentração da expansão urbana da cidade em área contígua à sua linha, com diversos loteamentos, favorecendo processos de segregação socioespacial, "onde o centro era habitado pela elite oligárquica e pela emergente classe de comerciantes e donos de fábricas, enquanto junto à ferrovia viviam operários, ferroviários e pequenos comerciantes" (LIMA, 2007, p. 45). Enquanto é possível observar crescentes investimentos na ferrovia nas décadas de 1910 e 1920, por outro lado a economia cafeeira encontrou-se em decadência na cidade durante o período de 1934 a 1950, acompanhando as transformações econômicas do estado e do país. Em São 
Carlos, a infraestrutura foi aproveitada pela indústria, que preferiu instalar galpões fabris em terrenos próximos à estação ferroviária (Ibid.).

Após isso, a história da ferrovia no Brasil é marcada pela concorrência, com o transporte rodoviário, ao invés da complementação. Nos anos 1950, a produção e consumo do automóvel foi incentivada por causa das opções políticas propostas durante o governo do então presidente Juscelino Kubitschek. Com isso, muitas rodovias foram construídas, alterando significativamente as características dos transportes em grandes regiões brasileiras. Em contraponto, as ferrovias foram desvalorizadas e a crise do petróleo na década de 1970 contribuiu para essa desvalorização. Concessões sobre o uso da ferrovia à iniciativa privada foram dadas na segunda metade da década de 1990. Hoje, o transporte ferroviário é demarcado por deficiências físicas e operacionais, operando no limite de sua capacidade de transporte de cargas, geralmente não perecíveis e de baixo valor agregado, como grãos e minérios (IPEA, 2013).

Sobre a dimensão política, é relacionada à própria questão do CDHU e também ao trajeto da ferrovia dentro da cidade. Atualmente, o transporte de carga por trem corresponde a todo o uso da ferrovia em São Carlos, não havendo mais transporte de passageiros. Notase periculosidade devido ao alto número de acidentes, envolvendo tanto veículos quanto pessoas. Supõe-se que grande número de pessoas na cidade gostaria de alterar esse trajeto, devido aos acidentes e por essa reivindicação ser feita em outras cidades da região e do país, algumas resultando em ações efetivas da mudança do trajeto dos trilhos pelo poder público ou das empresas concessionárias.

Observa-se através desse panorama que a ferrovia possui grande importância na história da cidade de São Carlos, contudo seu trajeto físico atual aparenta ser incompatível com a vida urbana em uma cidade que expandiu-se e transformou-se.

No caso da intervenção aqui proposta, que remete ao contexto do CDHU, através da troca de contextos é possível realizar uma aproximação de realidades distantes, em que os usuários da Praça do Mercado são colocados no contexto do outro através do relocamento sonoro; em alguns casos também promover relações de identificação por compartilharem o mesmo contexto.

Os sons do trem durante a intervenção fizeram surgir diferentes interpretações e percepções sobre o espaço da praça com o som do trem, como será demonstrado nesse capítulo. A intervenção também suscitou indagações e reflexões sobre o efeito que a 
ferrovia exerce sobre a cidade.Através da consideração dos dois locais, CDHU e Praça do Mercado, em conjunto com seus entornos sonoros respectivos, faz-se necessária uma investigação anterior à intervenção para maior entendimento dos entornos sonoros abordados, caracterizando o experimento como um processo em etapas.

\section{Caminhando para ouvir, ouvindo para entender}

Tratando a intenção de explorar justaposições entre entornos sonoro e físico, a coleta de áudio das duas localidades é estruturante para a análise do experimento como um todo. Para tanto, optou-se pelo método soundwalk, conhecido no campo disciplinar dos Estudos de Som e utilizado para o estudo do entorno sonoro, dialogando com urban design (ADAMS et AL., 2008; SEMIDOR, 2006; VENOT, SEMIDOR, 2006).

O método soundwalk consiste em gravar sons em um trajeto determinado, em diferentes momentos. Em conjunto com as coletas de áudio, também foram feitos registros de vídeo durante o trajeto para melhor caracterização do local, bem como para entender suas dinâmicas urbanas. Esses procedimentos nos locais são importantes para fornecer insumos para a comparação com o momento da intervenção, e servem como material de campo que auxilia o entendimento do entorno sonoro do local, relacionando-o com conceitos teóricos da pesquisa.

Como abordado no primeiro capítulo dessa dissertação, o entorno sonoro é reflexo das ações que ocorrem no espaço por ter relação direta com o movimento devido sua própria natureza física. Se o entorno sonoro de uma localidade é derivado também de ações físicas, ou de dispositivos tecnológicos sonoros utilizados pelas pessoas, cada entorno sonoro possui nuances e detalhes próprios correspondentes ao uso que se faz do espaço físico, podendo produzir identidades sonoras próprias em cada localidade. São produzidas co-relações intensas entre som e espaço físico e que não são fixas, dada a dinamicidade das ações que ocorrem no espaço físico. Dessa perspectiva, verifica-se a importância da investigação precedente à intervenção. 


\section{Soundwalk: construção de entendimentos sobre o entorno}

sonoro acústico

Catherine Semidor (2006) compreende o método soundwalk como uma forma de considerar a cidade além da abordagem visual. A autora identifica que o método é inspirado pelas noções de imaginabilidade e legibilidade de Kevin Lynch (1982), ${ }^{4}$ e que demonstram ser conceitos que auxiliam a observação e investigação da cidade e seus elementos (SEMIDOR, 2006). O método soundwalk, portanto, contribui aos Estudos de Som e também à Arquitetura e Urbanismo reunindo conceitos dos dois campos disciplinares e pode ser utilizado para investigações que envolvem espaço físico, urbanismo e entornos sonoros.

Diferentes autores (ADAMS et AL., 2008; SEMIDOR, 2006; VENOT; SEMIDOR, 2006) aproximam o método ao conceito de paisagem sonora, considerando-o uma forma que conduz à sua melhor identificação. Devido às questões expostas no primeiro capítulo dessa dissertação, não se associa o soundwalk à visão ecológica dada por Schafer (2001), a fim de não julgar de forma antagônica as qualidades do entorno sonoro e considerando ele reflete dinâmicas que ocorrem no espaço. Porém, entende-se que esse método auxilia a compreensão do entorno sonoro e contribui para o entendimento de sua dinamicidade.

Através da consideração de que sons são parte da identidade de uma cidade, o que é apoiado também por Michael Southworth (1969), Catherine Semidor (2006) aponta o método soundwalk como uma forma de se avaliar o som de espaços abertos, pois possui características específicas para a captação de áudio e também estrutura-se a partir da coleta de registro fotográfico e de vídeo. Tal método se revelou útil para registrar sons dos espaços públicos referenciados pelo experimento, atendendo à abrangência do local, além complementar a observação não-participante de tais locais.

De acordo com Semidor (2006), o som da cidade resulta de uma ampla variedade de fontes, a qual a gravação torna-se ferramenta para preservar a especificidade sonora de locais urbanos. Não somente as fontes sonoras são variadas, mas também dispersas e móveis.

\footnotetext{
${ }^{4}$ Conceitos abordados no primeiro capítulo desta dissertação.
}

Ouvir outros espaços: entornos híbridos, interfaces sonoras em espaços públicos :: 
Tratando-se de uma 'caminhada', o método soundwalk pode cobrir uma área ampla, onde o pesquisador percorre um trajeto definido gravando sons com equipamento de áudio apropriado. Além disso, o método também permitiu captar o áudio sob a subjetiva de um pedestre, coletando áudio de variadas fontes sonoras nos dois locais, CDHU e Mercado. O método soundwalk possui algumas demandas necessárias à sua realização. Estas são, de acordo com Semidor (2006):

- Definição de um trajeto específico a ser conduzido em variados horários e dias da semana, considerando dias úteis, fins de semana ou feriados. O trajeto deve ser definido de acordo com os objetivos da investigação;

- Gravação de áudio estéreo, em dois canais, para que possa ser identificada a localização da fonte sonora entre direita e esquerda e que seja preservada parte da difusão sonora. A gravação deve ser realizada na altura dos ouvidos do pesquisador, pois o áudio terá maiores correspondências ao que as pessoas que utilizam o local ouvem;

- Registro de fotos do trajeto, que promovem informação do espaço físico e das fontes sonoras presentes.

Semidor (2006) aponta também que, para a análise do material, é necessário ouvir cada canal repetidas vezes, anotando todos os componentes sonoros e sua recorrência, para então realizar uma tabulação de acordo com a intensidade sonora e distribuição das frequências.

O método soundwalk foi adaptado para corresponder aos interesses da pesquisa. O método foi realizado em ruas do CDHU e na praça do Mercado Municipal de São Carlos. O trajeto foi traçado privilegiando somente a área de pedestres do Mercado Municipal e as calçadas das ruas do $\mathrm{CDHU}$, principalmente nas ruas das proximidades da linha férrea. Evitando interferir muito para não chamar a atenção das pessoas, foi utilizado um gravador profissional portátil com dois microfones embutidos, realizando gravação estéreo, todas com o ganho (gain) na mesma intensidade, e uma câmera DSLR para gravar vídeo durante o trajeto. Os registros de vídeo e de foto dos locais colaboram para entender a configuração física e as atividades inscritas no local.

Como Semidor (2006) também define, o som é constante e flutuante, não podendo ser coletado de maneira completa e integral. Contudo, o método soundwalk é uma alternativa viável enquanto ferramenta de pesquisa para obter-se uma média distribuída de sons, limitando material coletado. 


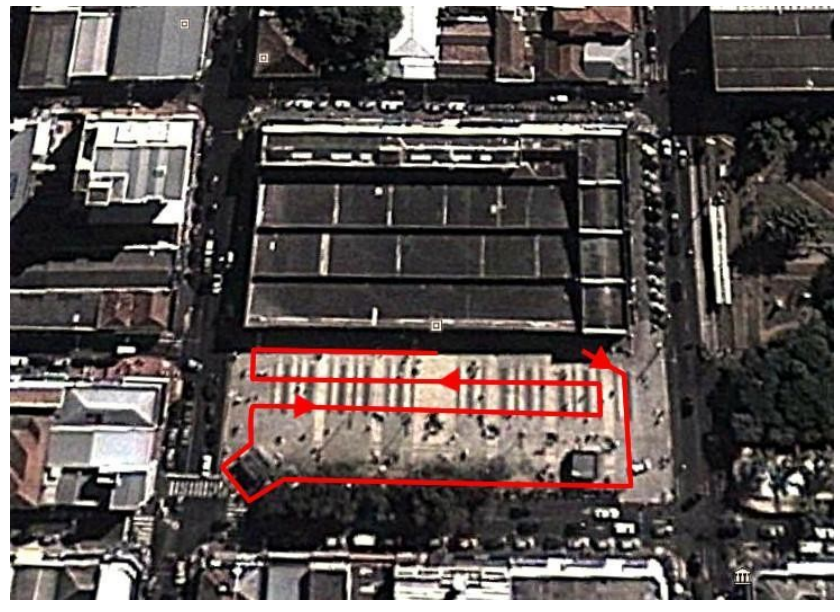

Imagem 16: Trajeto soundwalk na praça do Mercado, de aproximadamente $350 \mathrm{~m}$. Fonte: autora sobre imagens de satélite do Googlemaps

Imagem 17: Trajeto soundwalk no $\mathrm{CDHU}$, de aproximadamente $1100 \mathrm{~m}$. Fonte: autora sobre imagens de satélite do Google Earth.

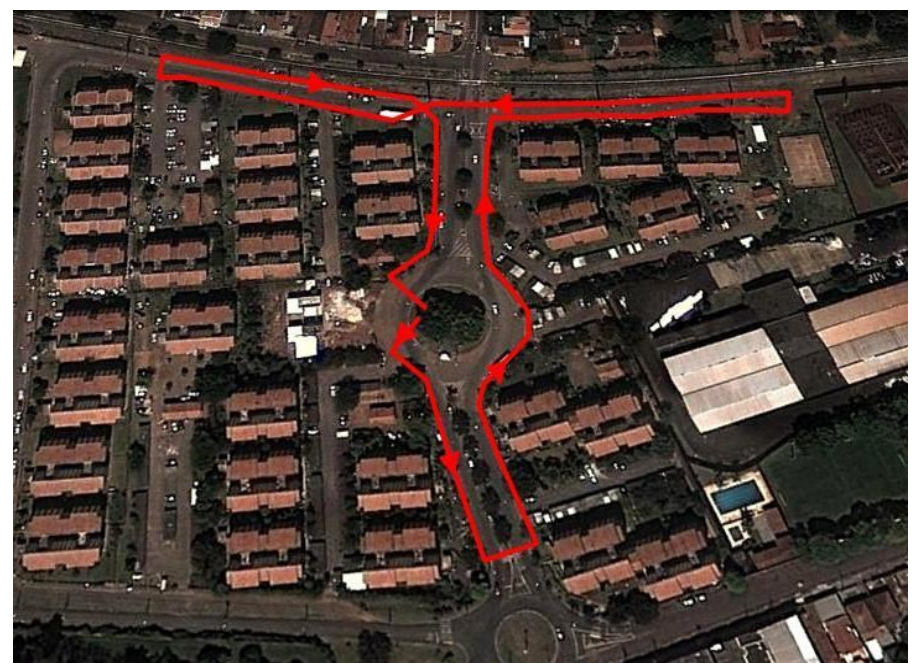


Através desse método foi possível identificar nuances sonoras contidas nos dois locais, decorrentes tanto de sua localização, a configuração física e quanto ao uso desses espaços, apesar de ambas possuírem uma quantidade de tráfego de veículos relevante que acoberta outras fontes sonoras. O tráfego de veículos é um elemento sonoro em comum, mas existem diferenças da diversidade de veículos e de sua regularidade de trânsito, bem como da dissipação do som em relação ao espaço físico.

O método soundwalk pode ser considerado um método de observação estruturada, o qual há gravação sistemática de áudio. Trata-se de coletar informações de base através da ida ao local estudado, o que contribui também para maior entendimento da configuração de elementos sonoros e do estabelecimento de relações entre audição e visão.

Para maior apreciação da análise de frequência dos áudios, consideraram-se:

- Frequências abaixo de $120 \mathrm{~Hz}$ provenientes principalmente do tráfego, podendo chegar até $300 \mathrm{~Hz}$;

106 - Frequência média da voz humana como 500 Hz;

- Pássaros com variação de 3150 Hz a 12500 Hz. 

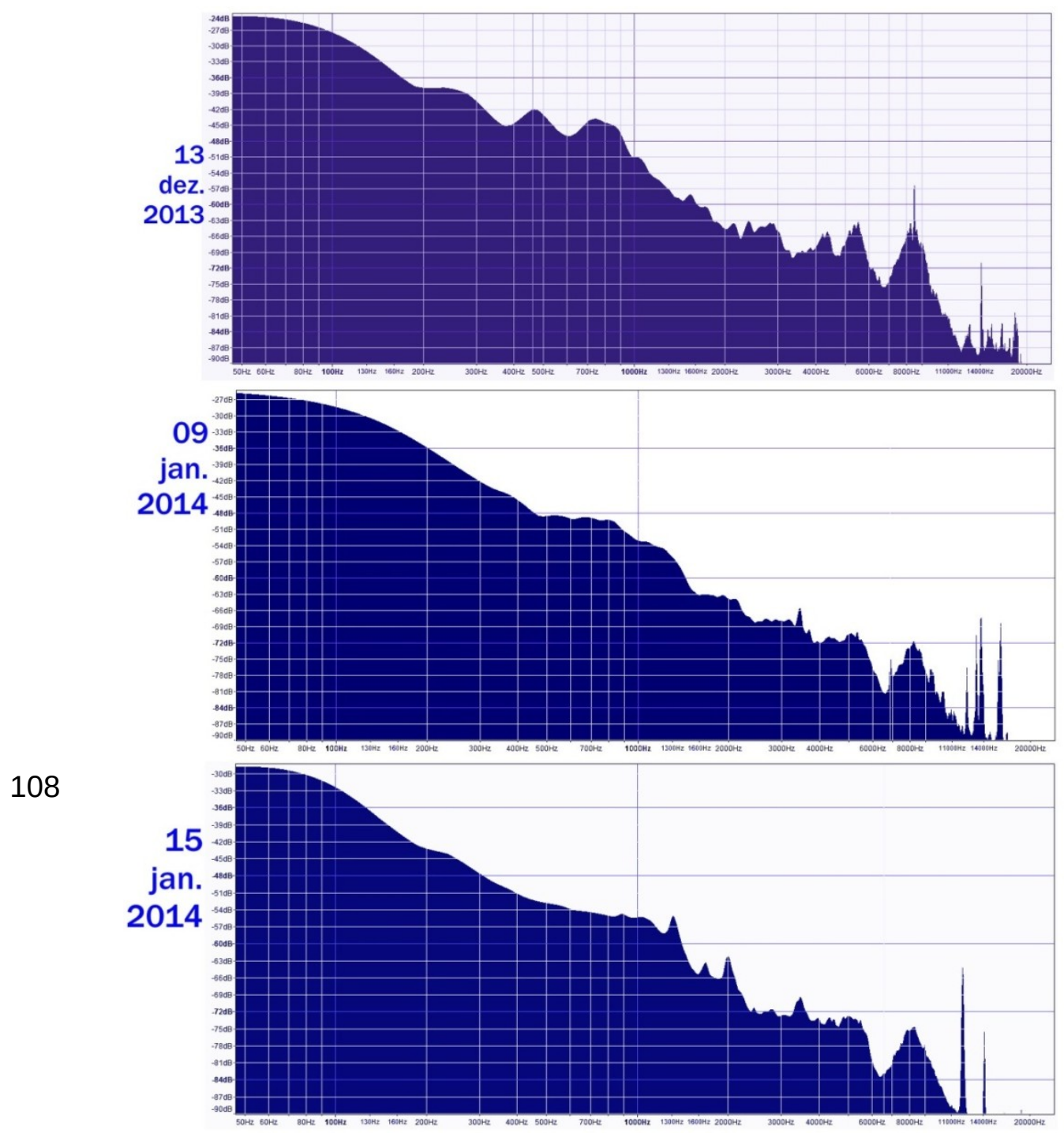

Imagem 19: Gráficos da análise de frequência de partes do áudio coletado na soundwalk na praça do Mercado, em eixo de frequência logarítmica (horizontal) e nível sonoro em dB (vertical), função Hanning Window. Fonte: autora.

De acordo com gravações de áudio realizadas em três dias distintos anteriores à intervenção, em diferentes horários, é possível identificar as seguintes fontes sonoras disponibilizadas aqui em ordem não hierárquica:

- Sons referentes ao deslocamento motorizado: motos, carros, ônibus, buzinas e freios;

- Sons oriundos de pessoas: pessoas conversando, crianças brincando, passos, sons de 
uso de ferramentas;

- Sons relativos ao comércio: sacolas, buzinas de sorveteiros, vendedores ambulantes vendendo mercadorias;

- Sons acusmáticos e mediatizados: carros de som com ofertas do comércio, carros tocando música, celulares;

- Sons oriundos de animais: bem-te-vi, maritaca (pontual, em apenas um áudio).

Tais fontes sonoras são cotidianas, contudo são reflexo dos usos dos locais. O deslocamento motorizado demonstra tanto o uso do local como conector de localidades importantes para a cidade quanto a concentração de veículos. Por ser dado pausadamente em ciclos e apresentar velocidade reduzida, é possível perceber através de seu conjunto sonoro a existência de reguladores de trânsito e consequente deslocamento de pedestres, além da alta concentração de tráfego. Essas características denotam o uso do local, concentrado ao comércio.

A presença de sons de ferramentas se refere ao trabalho, assim como o trabalho se apóia na atividade comercial e se relaciona a outros elementos sonoros, como por exemplo sacolas e passagem das pessoas que aparenta ser motivada pelo comércio.

Atribuindo uma dimensão histórica aos elementos sonoros, é possível perceber que alguns elementos estão presentes nas cidades há muito tempo, como apontam escritos de época e pesquisadores como Garrioch (2003). As feiras de bairro e o comércio se valiam, e ainda se valem, de vozes para fazer propaganda do produto; vendedores ambulantes anunciavam a sua passagem e seu serviço oferecido: a voz era, e ainda é, elemento importante para o comércio, e utilizava variação e repetição de ritmos e alturas, de grave a agudo, para melhor inteligibilidade (GARRIOCH, 2003). As falas de vendedores ambulantes, vozes fazendo propaganda de produtos, ou sons característicos como buzina de sorveteiro, podem remeter a sons que podem se encontrar também em outras épocas.

Os carros de som, contudo, aparentam ser uma releitura com sonoridade mais intensa da voz como forma de propaganda de produtos. Os carros de som possuem a particularidade de terem muita locução, colocando a voz falada em detrimento do jingle musical. A voz falada, sob a forma de locução, auxilia a inteligibilidade, contudo com pouca variação de 
alturas $^{5}$. A propaganda de produtos através da voz pode ser comprovada historicamente através de desenhos, pinturas, e escritos nas cidades européias desde a idade média, como aponta Garrioch (2003).

Os carros de som, contudo, algumas vezes se referem à lojas que não se encontram nos arredores, como por exemplo supermercados. Assim, os carros parecem aproveitar a concentração de pessoas que o local possui para anunciar as ofertas.

Em uma área não compreendida pelo método soundwalk, o "calçadão", rua dedicada a pedestres que é próxima do mercado municipal, é possível também encontrar caixas de som em frente às lojas, geralmente com o som de rádio ou com locutores falando ofertas ao microfone, contudo com voz com pouca variação de altura. É possível perceber nessa área comercial da cidade uma "disputa sonora" dos consumidores; que, no entanto, pode também resultar no afastamento dos mesmos pelo excesso e redundância de falas. A concorrência entre as lojas é colocada também através de informações sonoras, e esse fator se estende também às ruas ao redor do Mercado Municipal através da escuta acusmática, mediatizada, de carros de som.

Os carros de passagem, ouvindo música alta, podem refletir a leitura de que o motorista e os passageiros do carro queiram se isolar sonoramente do tráfego e dos arredores, apropriando-se do entorno sonoro à sua volta através da intensidade e limitando sua escuta à sua escolha. Conforme Raimbault e Dubois (2005), a intensidade sonora da música amplificada pode atribuir maiores danos fisiológicos aos ouvidos quando comparados aos sons relativos ao tráfego, contudo a música se refere a um entretenimento pretendido, uma escolha do ouvinte, e possui um valor social

Contudo essas músicas, quando em intensidade muito alta e por conseguinte abrangendo áreas além do veículo, podem se revelar como uma perturbação para as pessoas fora do veículo que não compartilham o mesmo gosto musical.

O som do tráfego, ainda que tendo como referência o centro da praça, se dá de maneira proeminente e tem suas frequências predominantemente graves, destoadas com o som de falas e burburinhos das pessoas. Há maior intensidade de frequências graves, abaixo de $100 \mathrm{~Hz}$. Essa gama de frequências é relacionada com o tráfego, que gera um entorno sonoro constantemente denso. Na gravação, há esse som constante de frequências

${ }^{5}$ As variações de alturas nas falas em carros de som são pequenas quando comparadas a alguns vendedores de feira, que não utilizam equipamentos de amplificação para a sua voz e costumam adicionar várias notas repetitivas em suas falas. 
graves, no qual não é possível perceber uma fonte sonora distinta.

Ainda que seja possível ouvir burburinhos e falas de pessoas em variadas cidades, a fala é um fator importante que reflete aspectos culturais e sociais através de sotaques, e também estados de espírito através de tom de voz. Nas gravações é possível ouvir risadas altas, algumas crianças brincando, pessoas conversando calmamente com sotaque característico.

É possível perceber que, na data de 13 de dezembro, quando a praça possuía alguns enfeites dada a ocasião do Natal, havia maior número de crianças brincando e correndo. Esse áudio corresponde a uma ocasião especial, dada a relação da praça com o comércio.

É possível reparar que o pico em intensidade das frequências graves durante o início da noite, quando o comércio está fechado e há menor tráfego de veículos, se dá na gravação como $-30 \mathrm{~dB}^{6}$; enquanto que em horário comercial corresponde a $-27 \mathrm{~dB}$ no dia 13 de dezembro e -24dB no dia 09 de janeiro.

A Praça do Mercado possui um entorno sonoro intenso, que não possibilita uma abrangência muito ampla de escuta. Os sons que podem ser ouvidos em maior distância são sons que são amplificados por interfaces sonoras. Detalhadamente, com nuances, é possível ouvir apenas as proximidades.

\footnotetext{
${ }^{6}$ É relevante lembrar que a escala em dB não é linear e sim logarítmica. Em áudio digital o pico máximo alcançado é $0 \mathrm{~dB}$, operando somente em valores negativos. 


\section{Entorno Sonoro: CDHU}

O CDHU, ao contrário da Praça do Mercado, não tem atividades comerciais suficientemente numerosas para determinar ciclos de atividades. Contudo, observando-se de maneira geral, as atividades parecem estar pautadas por horários escolares e de trabalho por ser um local residencial. Através da coleta de áudio e visitas ao local é possível perceber, de maneira geral, uma intensidade de tráfego relevante, proveniente de veículos diversos como carros, motos, ônibus e caminhões.

A Rua da Paz, onde se encontra uma praça que os moradores chamam de Praça da Mangueira, interliga dois bairros importantes que possuem acesso a uma rodovia vicinal, além de possuir várias empresas transportadoras nos arredores. Também foi possível perceber um som mecânico constante, de frequência média-grave, vindo de indústria ao lado do condomínio 3.

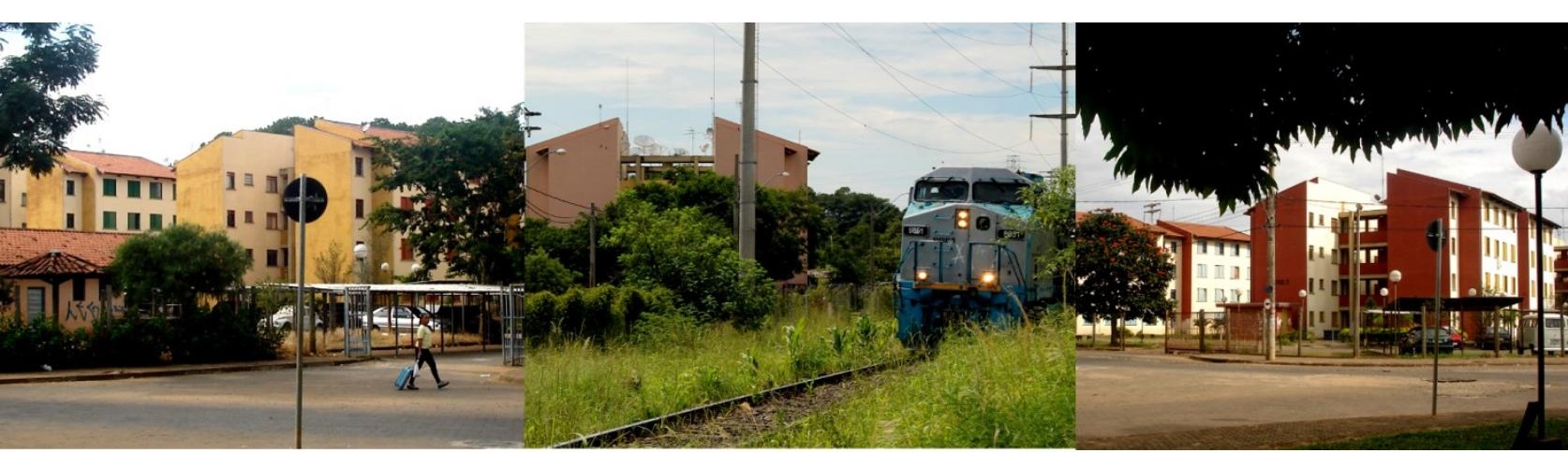

Imagem 20: fotos do CDHU. Fonte: autora.

Apesar do som proveniente do tráfego e da indústria, outras nuances sonoras se fazem presentes nas ruas como pássaros, pessoas conversando e crianças brincando. São identificadas as seguintes fontes sonoras, de forma não hierárquica:

- Sons relativos ao tráfego: motos, carros, ônibus, caminhões que, em muitos casos, fazem estrondos na carroceria devido à passagem de nível sobre os trilhos da ferrovia, freios, carros saindo da garagem, carroça (apenas em um áudio, pontual), bicicleta, trem.

- Sons oriundos de pessoas: pessoas conversando e crianças, concentradas na Praça central da mangueira e nas adjacências dos condomínios 3 e 4 . 
- Sons de equipamentos técnicos: zumbido de frequência média-grave constante, proveniente da indústria ao lado do condomínio 3, podendo ser ouvida principalmente nas adjacências desse condomínio.

- Sons mediatizados: sons de dispositivos como alarme sonoro do cruzamento, alarme de carro, alarme de manobra de caminhões; sons de música vinda dos apartamentos, carros tocando música.

- Sons de animais: pássaros diversos, de maneira constante na rua Prof Prof. Francisco Sampaio; cachorros.

Imagem 21: Gráficos da análise de frequência de partes do áudio coletado na soundwalk no $\mathrm{CDHU}$, em eixo de frequência logarítmica (horizontal) e nível sonoro em dB (vertical),

função Hanning Window. Fonte: autora.
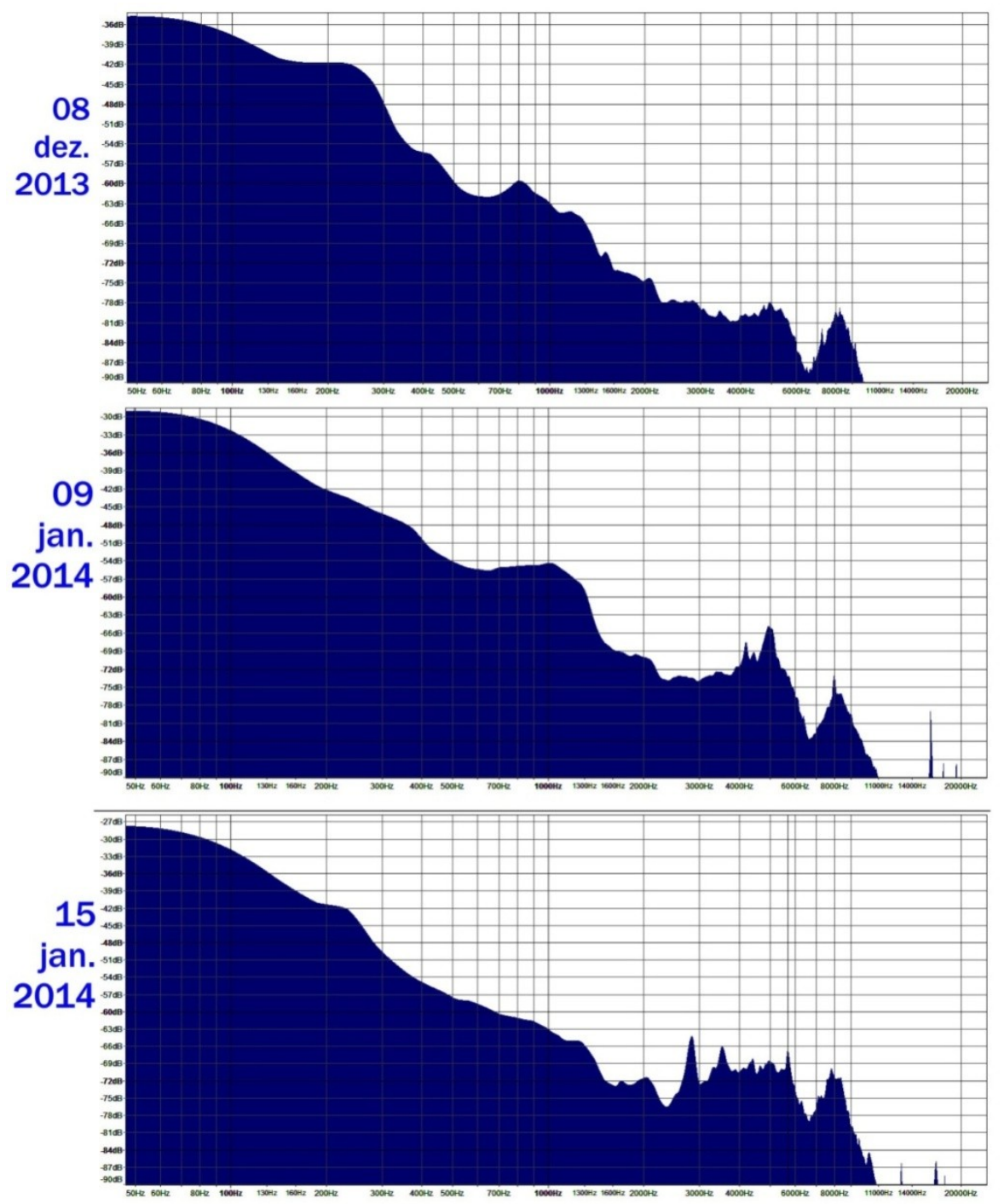
O trem realiza cruzamento em nível com a rua que interliga o condomínio com outros bairros, que dão acesso a uma rodovia vicinal. Esse cruzamento dispõe de um alarme sonoro que se caracteriza como a única forma de alerta de passagem do trem, não havendo cancelas para impedir passagem de veículos sobre a linha. Durante a soundwalk realizada em um momento de passagem do trem, o alarme pôde ser ouvido de forma clara, consideravelmente reverberante, até as adjacências dos condomínio 1 e 2. Nessa parte do trajeto havia um ponto de ônibus no qual as pessoas não direcionaram o olhar ao cruzamento, sugerindo familiaridade com o som.

Há uma diferença significativa entre a análise de frequências do áudio do CDHU durante a passagem de trem e sem ele, com o som coletado em locais semelhantes: ambos na Rua Prof. Francisco Sampaio, uma na direção do condomínio 3 e outra na direção do condomínio 4. Com a passagem do trem, as frequências graves se elevaram na gravação em até $10 \mathrm{~dB}$, bem como nas frequências entre $300 \mathrm{~Hz}$ e $1000 \mathrm{~Hz}$.

Os reflexos das ações sociais no entorno sonoro do CDHU se dá principalmente na Praça da Mangueira, no centro do CDHU entre os condomínios. Os condomínios são separados entre si por muros, o que concorre para dificultar o encontro casual e a interação social 114 entre moradores de condomínios diferentes. Devido esse fator, pode ser que a Praça da Mangueira se estabilize como um local neutro e de reunião entre esses moradores. A praça geralmente possui vans comerciais, uma por vez, às vezes vendendo bilhetes de "raspadinha", outras caldo de cana, ou cerveja.

O entorno sonoro também é mais intenso na Rua Prof. Francisco Sampaio, na altura do condomínio 3, onde crianças se reúnem em seu tempo livre para brincarem. Por consequência, alguns adultos se reúnem na área externa dedicada ao condomínio 3.

Os ciclos sociais de dinâmicas da localidade se pautam, muitas vezes, pela passagem dos ônibus no ponto. Contudo, ainda que em dias de semana, é possível observar moradores durante horários comerciais nos condomínios, conversando, e talvez fazendo companhia para as crianças, principalmente em horários próximos ao meio dia.

As músicas tocadas em carros também são em alta intensidade, porém mais pontuais. A configuração física do local pode cooperar para que esses sons se dissipem por uma área maior. Também é possível ouvir algumas músicas tocadas em apartamentos, o que sugere a aliança entre atividades domésticas variadas e o ato de ouvir música.

\footnotetext{
${ }^{7}$ Nome atribuído a jogos de azar em que se raspa um cartão para obter prêmios. 


\section{Praça do Mercado e CDHU: diferenças sonoras}

O CDHU, apesar da problemática sonora da passagem do trem, possui uma maior diversidade de elementos sonoros quando comparado à praça do Praça do Mercado. A área coberta pela soundwalk no CDHU é bem mais extensa, o que pode cooperar para esse fator. Contudo, reconhece-se que os usos dos dois locais são bem diferentes, principalmente pelo CDHU ser um local residencial, de moradia. As atividades sociais também aparecem de forma mais concentrada na Praça do Mercado, por ser um ponto convergente em que pessoas de várias regiões da cidade vão para fazer compras.

Há diferenças e, claro, similaridades entre os dois entornos sonoros. Tais diferenças se dão não somente pela sua configuração física, mas também seu uso.

A Praça do Mercado parece possuir abrangência sonora mais limitada quando comparada ao entorno sonoro do CDHU: no CDHU há menor concorrência de intensidade dos elementos sonoros, e o espaço físico colabora para a dissipação. Na Praça do Mercado, tanto na audição quanto na gravação dos sons, a perspectiva sonora parece mais restrita e, consequentemente, mais atrelada à visão: o entorno sonoro parece ser circundado e limitado pelas ruas, sendo possível ouvir além delas apenas elementos de alta intensidade sonora, como carros com alto-falantes. As vozes das pessoas também soam com menos detalhes, não sendo possível muitas vezes distinguir as palavras da fala, necessitando maior aproximação. Já no CDHU, é possível perceber maior abrangência, necessitando menor aproximação principalmente de fontes como o alarme do cruzamento, trem, e outros elementos de tráfego. Para a escuta de vozes e entendimento da fala não é necessária tanta aproximação quando comparada à Praça do Mercado.

Quanto ao espaço construído, que influi sobre o entorno sonoro através de fenômenos físicos, ambas localidades favorecem a difusão do som, porém de maneiras diferentes. No CDHU é possível perceber maior reverberação de sons de intensidade alta e maior abrangência da escuta, podendo ouvir-se mais longe. A Praça do Mercado, apesar de possuir um espaço físico que propicia a difusão sonora, notou-se que a abrangência da escuta é mais limitada. Esse fator se dá principalmente pela intensidade sonora de seus arredores, que acoberta nuances dos sons. Essa informação foi útil para o desenvolvimento da intervenção, pois se percebeu que seria necessária alta potência de 
som para que a reprodução dos sons do trem alcançasse a maior área possível.

Como ponto de convergência, é possível observar o tráfego nos dois entornos sonoros estudados, ainda que com diferenças qualitativas de elementos devido à variedade de fontes sonoras, bem como ciclos. O CDHU é um local relativamente plano, sem semáforos, o que colabora para que o som do tráfego seja mais fluido. Além disso, os dois espaços possuem usos e dinâmicas diferentes, assim como Lefebvre (2004) sugere que as vizinhanças e bairros possuem ritmos e ciclos diferentes, contribuindo para o reflexo dessas diferenças em seu entorno sonoro.

O som de fundo dos entornos sonoros, que se dá a partir de sons constantes que se configuram como uma base, também é fator decisivo na questão de como os outros elementos sonoros se sobressaem. Dessa maneira, no CDHU, o som do trem pode ser percebido com maior ênfase à frente do som de fundo.

Os sons de animais, pássaros e cachorros, podem ser mais ouvidos no CDHU. Por ser um local residencial, é onde se encontram os animais de estimação. Além disso, o som de pássaros também denota que o CDHU se encontra em um local mais periférico da cidade, com mais áreas verdes nos arredores.

Apesar dos entornos sonoros não aparentarem ser formados por sons singulares e únicos, pois esses sons podem ser encontrados de maneira similar em outras cidades, tanto a Praça do Mercado quanto o CDHU são providos de sons marcantes que juntos caracterizam seu entorno sonoro, refletindo os movimentos, dinâmicas e costumes. Além disso, o entorno sonoro também é influenciado pelas características físicas do local, contribuindo também para a sua singularidade. O entorno sonoro reflete, portanto, características que muitas vezes não podem ser percebidas somente no campo visual. Assim, a avaliação do entorno sonoro auxilia processos de análise e caracterizações tanto de espaços físicos quanto o seu uso, pois o entorno sonoro reflete qualidades do espaço.

Os mesmos sons podem se apresentar de maneira similar em outros locais da cidade, contudo similaridade não quer dizer igualdade. As características físicas dos locais influenciam muito, além de cada um dispor arranjos e organizações diferentes. É a partir dessas organizações dos elementos do entorno sonoro que é possível identificar os ciclos e repetições as quais Lefebvre (2004) se refere, refletindo a organização social inscrita ao espaço. 


\section{Reverberação Urbana: o trem intervém na praça}

Primeiramente, busca-se trazer à luz as atividades realizadas durante a intervenção, para então realizar considerações gerais sobre entrevistas e métodos de registro, para então realizar a análise. A atuação e tomadas de decisões realizadas pelos pesquisadores, influenciaram qualitativamente na intervenção como um todo.

A realização da intervenção se deu a partir das 9 horas até as 17 horas. Para proveito da intervenção como um processo de pesquisa, foi estipulado que o áudio com os sons do trem seria reproduzido a cada meia hora. Quatro caixas de som estavam em frente à fachada do Mercado Municipal, formando uma linha paralela à parede. Devido ao objetivo de reproduzir o som de forma que se assemelhasse à passagem de um trem, o áudio foi distribuído em dois canais, esquerda e direita, dando a impressão de chegada e saída do trem. Para esse objetivo ser alcançado, foi necessária a reprodução em alta intensidade sonora.

Durante a parte da manhã, foi realizado um teste no qual foi reproduzido um dos áudios coletados do trem no CDHU sem edições, da forma como foi captado. Observou-se, no entanto, dada a passagem pontual de várias pessoas no local que o áudio coletado não era suficientemente longo para atingir um maior número de pessoas. Além disso, durante o teste percebeu-se que o som da buzina do trem era o elemento sonoro mais ativo, que despertava maiores reações, como por exemplo as pessoas saindo dos locais que se encontravam para conseguir ver do que o som se tratava. Portanto, o áudio coletado do trem foi editado e combinado com outros áudios, dando ênfase para a buzina e para o som das rodas nos trilhos. Na edição, preferiu-se não sobrepor variados sons de trem, e sim criar uma ilusão de continuidade de um mesmo trem. Também não foi realizada uma edição que conferisse ritmo ou cadência musical, por entender que não se trataria de uma forma de edição que desenvolveria bem os fins da intervenção. Esses assuntos serão discutidos nas categorias que analisam a visibilidade da interface e as reações do público.

Foram feitos registros de vídeo durante dois minutos antes de cada reprodução até dois minutos depois. Logo após o início de cada ativação do som, os pesquisadores se dispersavam pela praça para realizar entrevistas semi-estruturadas com as pessoas presentes no local. Nos intervalos, os pesquisadores se reuniam para trocar suas 
impressões sobre os acontecimentos.

No período da tarde, o áudio editado foi reproduzido com a mesma regularidade. Observou-se que o áudio editado contribuiu para ser realizado um maior número de entrevistas, pois possibilitou também entrevistas com pessoas que estavam de passagem. Às 17 horas, a intervenção foi finalizada.

\section{Considerações sobre as entrevistas e os métodos de registro}

Através de um planejamento realizado em com os pesquisadores Nomads.usp participantes da intervenção, optou-se por realizar entrevistas semi-estruturadas com gravação de áudio, com devido consentimento dos entrevistados.

118 De acordo com Fraser e Gondim (2004), a entrevista em pesquisa qualitativa "favorece 0 acesso direto e indireto às opiniões, às crenças, aos valores e aos significados que as pessoas atribuem para si, aos outros e ao mundo circundante", onde o entrevistado compartilha reflexões acessíveis no momento de interação com o pesquisador, em um processo de influência mútua.

Esse formato foi escolhido por atender às demandas de pesquisa e por possibilitar a abrangência dos tópicos considerados necessários de serem abordados: interpretações e reflexões sobre a justaposição de um determinado entorno sonoro (o conjunto dos elementos sonoros do trem do CDHU) sobre outro, da Praça do Mercado, tomando em consideração seu entorno físico; considerações quanto à influência dos sons do trem e da ferrovia no CDHU. Além disso, esse modo de entrevista possibilita ao entrevistador solicitar mais respostas através de questões neutras como "o que você acha disso?", buscando respostas mais complexas quando necessário.

O objetivo dessas entrevistas converge com o objetivo da intervenção, que reside em buscar compreensões sobre as percepções do espaço que surgem a partir da justaposição de entornos sonoros e físicos, formando entornos híbridos através do uso de interfaces sonoras, possibilitando o surgimento de outras apreensões do espaço. Dessa 
forma, as entrevistas promovem maior entendimento sobre essas percepções, angariando diversas naturezas de compreensão e reflexão, sejam positivas ou negativas. Além disso, as entrevistas também aproximam o entrevistado ao contexto do $\mathrm{CDHU}$, inserindo essa questão para estimular reflexões a respeito.

Cada pesquisador procurou entrevistar pessoas que estavam em situações de permanência e de passagem no local. Foram entrevistadas pessoas diversas, de variadas faixas etárias e gênero, acompanhadas ou não. Foram realizadas 65 entrevistas, que tinham como eixo três perguntas, feitas na seguinte ordem:

1. Você ouviu o som do trem? : estratégia para aproximação do pesquisador ao entrevistado.

2. O que você acha da praça com esse som?: com a intenção de estimular reflexões sobre a quebra de contexto, bem como dar abertura para a pessoa dar sua opinião.

3. Esse som foi gravado no $\mathrm{CDHU}$, onde o trem passa várias vezes durante o dia e durante a noite, o ano todo, e moram quase mil famílias. O que você acha disso? : colocando em contato com a questão do CDHU.

A pergunta sobre o CDHU possui caráter informativo e se dá pelo objetivo de aproximar o contexto do CDHU às pessoas na praça do Mercado. Através da informação sobre o CDHU, o entrevistado entra em contato com outros contextos a serem apreendidos naquele momento, seja o contexto do $\mathrm{CDHU}$ em relação à ferrovia uma realidade próxima da sua ou distante.

As entrevistas tiveram durações diversas: algumas foram realizadas de maneira muito pontual, as quais os entrevistados apenas adjetivavam suas impressões; outras tiveram duração de mais de dez minutos, quando o entrevistado demonstrava abertura ao diálogo, construindo reflexões mais complexas. Apesar dessa dissiparidade de duração, a maioria da duração das entrevistas foi de aproximadamente dois minutos. No dia da intervenção, algumas entrevistas foram realizadas também no CDHU com caráter e perguntas diferentes, perguntando o que as pessoas achavam do trem passando. Nessa ocasião foram realizadas somente duas entrevistas, além das conversas informais da primeira etapa do experimento. Folhetos explicativos foram entregues às pessoas entrevistadas e também às que não concordaram em conceder entrevista. O registro da intervenção foi realizado a partir de vídeos e fotos. De modo geral, foram escolhidas duas instâncias a serem registradas: o público, a fim de registrar suas reações, e a atuação dos 
pesquisadores, para registro de sua forma de organização e participação na intervenção. Os registros de vídeo foram direcionados apenas ao público, um com a câmera estática e outro com a câmera móvel, enquanto que os registros fotográficos se dividiram entre o público e os pesquisadores.

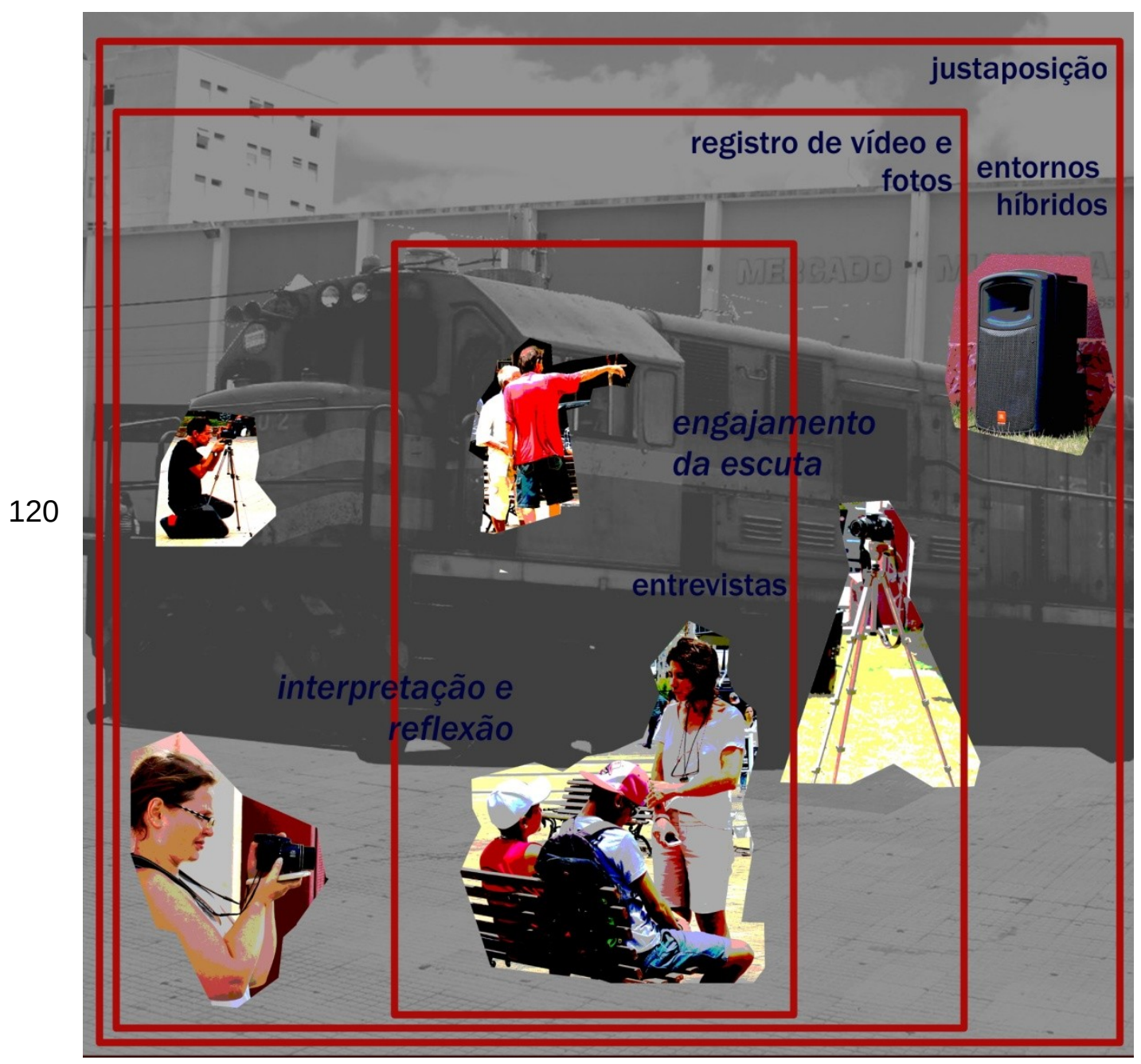

Imagem 22: diagrama da intervenção. Fonte: montagem de fotos do Nomads.usp pela autora. 
Divididos dessa forma, os registros auxiliam avaliação das reações do público considerando também o papel e a influência dos pesquisadores na intervenção. Os registros direcionados à atuação dos pesquisadores colaboram fornecendo insumos para futuras intervenções e também para a avaliação do processo da intervenção, refletindo sobre seu aspecto organizacional. Os registros colaboram também para divulgação científica, servindo como material bruto para a edição de um pequeno documentário ${ }^{8}$.

A partir dessas considerações gerais quanto ao desenvolvimento da intervenção, propomos aqui as seguintes categorias de análise: quanto ao direcionamento qualitativo dado pelas interfaces sonoras; quanto aos aspectos tecnológicos e, por fim, as reações do público. Entende-se que essas categorias se inter-relacionam sob escopo da intervenção, e se baseiam nos conceitos abordados na dissertação.

A categoria referente ao direcionamento qualitativo dado pelas interfaces sonoras, aplicada na leitura das intervenções sonoras no segundo capítulo, também se aplica a essa intervenção, por ser um espaço de reflexão quanto ao direcionamento que as interfaces sonoras, bem como seus processos de mediação, produzem sobre a intervenção como um todo.

Por estar inscrita em um experimento de pesquisa acadêmica, e por ter todas suas etapas acompanhadas, diferentemente das intervenções analisadas no segundo capítulo, viu-se a necessidade de aplicar categorias diferentes para melhor proveito da análise.

Diante disso, dado que as caixas de som estavam visíveis durante a intervenção, não sendo ocultadas, a categoria relacionada ao fator tecnológico analisa as consequências que a visibilidade da interface sonora promoveu sobre a intervenção.

A categoria das reações do público reflete sobre as atitudes das pessoas percebidas através dos registros de vídeo e de foto, bem como analisa o conteúdo das entrevistas. Para isso, essa categoria encontra-se subdividida em três itens: análise dos modos de escuta promovidos pela intervenção; interpretações e reflexões dos entrevistados, considerando o som como um elemento representativo; comentários feitos pelos entrevistados quanto ao CDHU, através das informações promovidas pelos

\footnotetext{
${ }^{8}$ https://www.youtube.com/watch?v=XUFV55-Ryhk
} 
entrevistadores na terceira pergunta.

\section{Direcionamento qualitativo dado pelas interfaces}

\section{sonoras}

Através da escolha dos sons do trem como um elemento representativo do CDHU, e também da própria cidade, dada sua importância histórica e o trajeto da ferrovia que torna o trem audível em vários bairros da cidade, o relocamento dos sons do trem no CDHU à praça do Mercado muda o contexto em que esses sons são ouvidos: cada local possui suas próprias dinâmicas espaciais e seu próprio entorno sonoro, ainda que possuidor de similaridades. Não há ferrovia na Praça do Mercado e os sons do trem não podem ser ouvidos com a mesma definição e a intensidade da forma que foram reproduzidos durante a intervenção.

Trata-se de uma troca de contextos, e não uma descontextualização total. Através da

122 transposição dos sons do trem à outra localidade, os sons adquirem outros significados de acordo com o contexto do local que é reproduzido. Isso é promovido através da característica conversacional da relação entre som e espaço.

Assim como em Sound Island, intervenção de Bill Fontana analisada no segundo capítulo, os sons têm seus significados transformados através de sua justaposição com o entorno sonoro acústico e espaço físico da praça, dialogando também com suas dinâmicas espaciais, sociais e históricas. Através dessas considerações, o termo "relocamento" representa melhor essa característica em detrimento do termo "deslocamento", que confere um sentido negativo, como afirma Emmerson (2012).

As interfaces sonoras implicam em processos tecnológicos nos quais se refletem intenções de pesquisa. Esses processos são: a captação de sons, que se deu na primeira etapa, resultando em seu armazenamento digital; escolha e edição do áudio, manipulado digitalmente; e reprodução, que envolve novamente processos de transdução envolvendo naturezas digital, eletrônica e som sob sua forma acústica. São envolvidas nesse processo instâncias virtuais, conferindo um entorno híbrido como resultado dado a partir de sua reprodução. 
Como desenvolvido durante essa pesquisa, esses processos não são neutros. A escolha dos sons do trem do CDHU, por si só, já implica em um direcionamento dado a partir da intenção do pesquisador. Esses processos se relacionam com intenções e objetivos, que no caso da intervenção se refere à justaposição dos sons do trem do CDHU, editados de forma a ressaltar seus aspectos considerados mais enfáticos, destacando sons da buzina e dos trilhos, dispostos em dois canais, realizando referências sobre a passagem de um trem.

Anteriormente à edição dos áudios, a captação feita com microfone direcional ${ }^{9}$, o que indica também opções da pesquisa. É possível, por exemplo, escolher captar com maior ênfase o som das rodas no trilho do trem, ou o motor da locomotiva, desde que sob as condições adequadas. Assim, verifica-se que esses processos não são neutros conforme aponta Sterne (2003) e demonstram intenções e objetivos desde sua captação.

Através de processos de gravação e reprodução é inscrito também o armazenamento do som em um estado estável, referente à questão da memória mecânica do som (EMMERSON, 2007), que implica em um afastamento espaço-temporal. Esses fatores também favorecem a escuta acusmática pautada pela cadeia de reprodução.

$\mathrm{Na}$ intervenção, essa ação de relocar os sons trata do direcionamento dado pelo pesquisador: consideram-se, nesse caso, os sons do trem como relevante para a escuta, podendo direcionar interpretações e reflexões das pessoas presentes em torno de um objeto compartilhado através da escuta coletiva, sugerido pela pesquisa. O conjunto de sons escolhidos e reproduzidos comporta-se como uma nova informação sobre espaço no qual é relocado. Estabeleceu-se a justaposição de um entorno sonoro o qual é manipulado digitalmente. Os processos de gravação, edição e reprodução reforçam características do entorno sonoro reproduzido como uma instância virtual.

A edição dos áudios coletados foi realizada para reforçar uma influência sonora de que um trem estivesse atravessando a praça. Contudo, em relação à passagem de um trem propriamente dito há outros fenômenos inscritos: a própria vibração que afeta tanto construções quanto o corpo das pessoas, a presença do trem que é impactante visualmente, a fumaça das locomotivas, o que pode colaborar para percepção mais prontamente. Tratando apenas do elemento sonoro do trem em movimento, foi necessário

\footnotetext{
${ }^{9}$ Nesse caso, foi utilizado um microfone shotgun, que possui abertura da área de captação restrita, captando com menor intensidade os sons fora dessa área.
} 
reproduzir os sons em intensidade e duração suficientes para conseguir maior efeito sobre as pessoas, bem como para se sobressair frente ao entorno sonoro prévio da praça. A reprodução em menor intensidade proporia outros efeitos sobre as pessoas, pois pareceria mais distante. Há também a possibilidade de que o som reproduzido teve que transpor determinado entorpecimento da escuta cotidiana das pessoas, e portanto deveuse ressaltar o seu elemento mais enfático: a buzina.

A buzina do trem trata de um elemento representativo, pois é utilizada quando o trem chega em áreas urbanas ou de maior concentração de pessoas, como por exemplo o trajeto intraurbano da ferrovia em São Carlos. Trata-se de um aviso, de que o trem está próximo, chegando na praça.

“Sinal de alerta, né?"10

O som reproduzido havia de se justapor com o entorno sonoro da praça em intensidade, não somente em méritos acústicos como também para tornar-se mais evidente em relação ao som do tráfego. Por esse fato, considera-se que para obter o efeito de relocamento pretendido pela intervenção, provocando um engajamento mínimo da audição através do direcionamento da escuta, o som reproduzido deveria ser acentuado e espacializado o suficiente para sugerir, através do som, que um trem estaria passando pela praça

Contudo, a intencionalidade sugerida através da visibilidade da interface, pode também indicar que o som reproduzido tem alguma proposta, sendo algo válido para escuta.

A amplificação, por sua vez, permite a escuta coletiva, estabelecendo uma composição de entornos sonoros compartilhada por várias pessoas na praça do Mercado. Trabalhou-se o som em dois canais, esquerdo e direito, com o cuidado de reproduzir o som de uma caixa à outra, acentuando a ilusão de uma fonte sonora em movimento.

Devido à troca de contexto, os sons do trem são elementos estranhos ao local e por esse aspecto toma a atenção do ouvinte e torna-se portador de uma mensagem, um elemento que estimula uma série de reflexões que normalmente não seriam feitas pelas pessoas naquele momento. Esse fator é catalisado através da atuação dos pesquisadores nas

\footnotetext{
${ }^{10}$ Nesse capítulo vários comentários anônimos são colocados nessa formatação e são provenientes das entrevistas semi-estruturadas. Quando necessária é realizada uma complementação da fala entre colchetes. Na transcrição, privilegiou-se a reprodução da linguagem coloquial não realizando revisões quanto concordâncias de verbos ou substantivos, no entanto são colocadas as pontuações necessárias presentes na fala para sua melhor reprodução e entendimento da escrita. Formas de expressões que são óbvias e claras na fala gravada, como por exemplo risadas, também são indicadas entre colchetes.
} 
entrevistas, fazendo perguntas que remetem a essa recontextualização e ao contexto do CDHU.

O alto-falante tem, com efeito, nos permitido criar um espaço acústico virtual no qual podemos projetar uma imagem de qualquer espaço acústico existente, e a existência desse espaço acústico nos apresenta novas possibilidades criativas ${ }^{11}$ (WISHART, 1996, p. 136).

Tomando em consideração tal perspectiva dada por Wishart ${ }_{2}$ percebe-se que há uma projeção de outro entorno sonoro. Os elementos sonoros do trem, gravados e editados, dão origem a um entorno sonoro gerado a partir de instâncias virtuais. O entorno sonoro da praça, que possui relação direta com ações que ocorrem no espaço, encontra-se com um entorno sonoro externo, estranho.

Esse entorno sonoro virtual, possibilitado por equipamentos tecnológicos de gravação, edição e reprodução, é por fim justaposto ao outro entorno, resultando em um entorno híbrido. Essa justaposição não se dá como um adereço ou complementaridade, pois faz surgir questões que normalmente o espaço da praça não suscitaria como, por exemplo, o efeito exercido pela ferrovia sobre a cidade.

Como Chion (1994) explica, o modo de escuta causal, em que o ouvinte procura a origem do som, também se refere a uma imaginação, pois o ouvinte pode imaginar aspectos físicos da fonte sonora quando não é possível vê-la, ou busca determinar uma natureza geral da fonte sonora. A escuta acusmática também reforça a atenção da escuta sobre si mesma. Dessa maneira, compreendendo o som como elemento que provoca imagens mentais, lembranças, e que produz emoções, os sons do trem em "Reverberação Urbana", por ser facilmente identificável, é capaz de oferecer um estímulo a associações feitas de maneira subjetiva de acordo com a experiência do ouvinte.

\footnotetext{
${ }^{11}$ Tradução nossa. "The loudspeaker has, in effect, allowed us to set up a virtual acoustic space into which we may Project an image of any real existing acoustic space, and the existence of this virtual acoustic space presents us with new creative possibilities." 


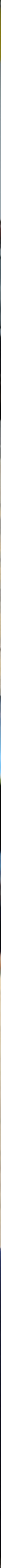


Em estudo direcionado à música eletroacústica, Denis Smalley (1996, p. 83) alega que

Os materiais sonoros inscritos em uma composição não podem ser somente ou mesmo principalmente auto-referenciais. A apreensão do conteúdo e estrutura musical está conectada ao mundo de experiência fora da composição, não só ao contexto mais amplo da experiência auditiva, mas também a experiência não-sonora. Abordados a partir das múltiplas perspectivas da vida além da música, os materiais e a estrutura de uma composição musical tornam-se o ponto de encontro da experiência sonora e não-sonora. ${ }^{12}$

Essa mesma perspectiva pode ser aplicada à estrutura da intervenção, dadas suas ressalvas, pois que a escuta direcionada à música se pode se dar de forma diferente; contudo, a troca de contextos do som favorece reflexões que interligam-se a um campo mais amplo de referências e experiências não necessariamente sonoras.

Gera-se, na intervenção, através dessa justaposição de entornos sonoros possibilitada pelo uso da interface, um locus propício para interpretações e reflexões diversas, não somente relacionadas ao som. Não se trata de um relativismo, onde cada um possui uma impressão própria que gera diversidades de interpretações que compromete o alcance de objetivos e conclusões, e sim se trata de singularidades de interpretações que podem ser abarcadas em um conjunto de temas.

\section{Quanto ao fator tecnológico: visibilidade da interface}

Intervenções como "Reverberação Urbana" são difíceis de serem realizadas pela necessidade do som reproduzido se justapor aos sons cotidianos, pois o som precisa ser reproduzido em alta intensidade.

\footnotetext{
12 Tradução nossa. "The sounding materials within a composition cannot be solely or even primarily self-referential. The apprehension of musical content and structure is linked to the world of experience outside the composition, not only to the wider context of auditory experience but also to non-sounding experience. Approached from the multiple perspectives of life outside music, the materials and structure of a musical composition become the meeting-place of sounding and non-sounding experience."
} 
A Praça do Mercado possui um espaço físico que favorece a difusão sonora, por ser um local aberto, ao mesmo tempo em que os sons de seus arredores são intensos. Para atendimento ao objetivo da intervenção de gerar a impressão de que um trem estaria passando pela praça, foram necessárias quatro caixas de som profissionais, cuja reprodução se deu em dois canais, estabelecendo espacialidade semelhante o quanto possível à passagem de um trem.

O fator tecnológico não reside somente no aspecto técnico de intensidade sonora. A visibilidade da interface se demonstrou um fator importante quanto à recepção da intervenção na praça e que também colabora para deixar aparente das intenções de pesquisa inscritas nos processos sonoros ${ }^{13}$. As caixas de som, dispostas paralelamente à fachada do Mercado Municipal, estavam sob alcance da visão de vários pontos da praça.

Não somente as caixas, como também o computador, placa de som, cabos e mesa de som. O processo tecnológico estava aparente a quem se interessasse.

A interface utilizada nessa intervenção não teve caráter transparente ou invisível. Isso remete à afirmação de Jay D. Bolter e Diane Gromala (2003), de que artefatos digitais são feitos para mudar o relacionamento do usuário em seu entorno físico e cultural; o design digital pode incentivar o usuário a revisitar seu contexto bem como responder a ele. Apesar da intervenção não pertencer ao âmbito do design digital, a transformação ocasionada pela intervenção responde ao contexto da praça e da cidade, configurando-se como um incentivo para o público a revisitar seu próprio contexto, além da experiência sonora. O som demarca claramente uma mudança e os equipamentos técnicos não estavam invisíveis: percebia-se claramente a presença das caixas de som e dos equipamentos, denotando também uma intenção em sua inserção.

Em oposição, a questão de invisibilidade da interface pode ser encontrada no conceito de ubiquidade. Mark Weiser (1991, p. 94) inicia seu artigo com a ideia de que "as tecnologias mais profundas são aquelas que desaparecem. Elas se entrelaçam no tecido da vida cotidiana, até que são indistinguíveis dela", sendo que esse "desaparecimento" se refere ao uso espontâneo e natural de tecnologia.

Contudo, a percepção da interface na intervenção não se dá de forma que o público deva

\footnotetext{
${ }^{13}$ Através da montagem dos equipamentos, bem como a visualização dos mesmos, pode-se deixar implícito que acontecerá algo e que possui alguma proposta, como será discutido brevemente a seguir.
} 
"ir" até a interface, por causa do caráter de ubiquidade que o som possui: o som reproduzido pelas caixas conforma uma arena sonora, nos termos de Smalley (2007), que abrange toda a praça através da escuta coletiva.

Amplificadores e outros equipamentos tecnológicos de reprodução sonora são inscritos na vida cotidiana de variadas formas, como por exemplo fones de ouvido, rádio, som de carro. Contudo, as caixas de som não são tão usuais quando consideradas junto ao contexto da praça e suas dinâmicas previamente estabelecidas. Apesar da obviedade da função das caixas de som, sua presença denota dois fatores que influem qualitativamente na intervenção: a intenção de inseri-las nesse contexto e a consideração das caixas de som enquanto fonte sonora.

Devido ao tamanho das caixas de som e às condições de instalação dos equipamentos na Praça do Mercado, a interface como um todo ficou exposta: as pessoas que conseguiam ver as caixas de som e demais equipamentos, sabiam que o som tinha sua origem ali, sendo que algumas demonstraram em entrevistas que deduziram que haveria algum propósito para as caixas instaladas. Vídeos de registro da intervenção mostram que algumas pessoas, movimentavam-se procurando a origem do som até poderem ver as caixas de som. Dessa forma, a presença das caixas de som proporciona uma relação de causa e efeito, onde o ouvinte procura a correspondência visual do que é ouvido ${ }^{14}$.

Alguns comentários obtidos pelas entrevistas deixam transparecer que as pessoas procuravam a fonte sonora com a visão; outras sentiram um estranhamento por saberem que não passa trem naquela região, de forma que desse para ouvir tão nitidamente. A visibilidade das caixas de som e dos demais equipamentos se deu como um fator que ameniza o estranhamento dado pelo som relocado, pois fornece um contexto sob o qual se justifica a origem do som.

As caixas de som tornaram-se pontos referenciais, que correspondiam à origem do som reproduzido, além de interferir na ordem cotidiana no local. Os equipamentos também denunciam na intervenção os processos da interface, da gravação e reprodução dos sons, e sugere intencionalidade no relocamento sonoro. Dessa forma, denotavam também não só a presença de sons recontextualizados, como também a presença das pessoas que os

\footnotetext{
${ }^{14}$ Essas questões serão discutidas mais profundamente no próximo item, porém esse aspecto exemplifica como o fator tecnológico influi qualitativamente na intervenção.
} 
promoviam: os pesquisadores. Em meio a um entorno sonoro típico e usual é claramente inserido um outro entorno, que pode gerar pensamentos não usuais, inclusive críticos ou negativos.

Podem-se interpretar as interfaces sonoras tanto como janelas quanto como espelhos, no sentido atribuído por Bolter e Gromala (2003). Em "Reverberação Urbana", a interface pode ser considerada uma janela, pois a interface permite que, através dela, as pessoas sejam colocadas em contato com uma outra realidade através da escuta de um som cuja origem está em outro espaço-tempo. Talvez a metáfora do enquadramento também seja válida: é delineada e escolhida uma questão que atinge vários moradores da cidade, delimitando um tema em comum entre as pessoas daquele local, o qual as pessoas podem comentar entre si. Enquanto espelho, a interface propõe um campo de reflexão relacionado ao trem, ferrovia e, em alguns casos demonstrados por entrevistas, moradia. Nesse caso, a interface auxilia o público a enxergar seu próprio contexto, promovendo relações com o som do trem.

De uma maneira mais superficial, as caixas de som podem ser interpretadas como um lembrete de que não é possível ouvir o som do trem naquela intensidade, naquele local. A reprodução fazia com que algumas pessoas inserissem o som no contexto sonoro da praça, considerando que o som poderia vir da estação ferroviária, a aproximadamente 700 metros.

Contudo, os sons do trem, como um forte elemento representativo, também aliados à história da cidade São Carlos, pôde refletir histórias de vida individuais, tanto positivas quanto negativas, que puderam ser externalizadas através das entrevistas. Histórias não somente no sentido de memória, mas também no sentido das experiências vividas que não são somente sonoras, e das relações realizadas pelas pessoas entre a situação e com seu próprio contexto.

Dessa forma, instaura-se uma dualidade entre o que é interpretado como poluição sonora e entretenimento com valor social agregado: enquanto o som do trem é considerado por vários entrevistados como um incômodo ou irritação, pode-se inferir que a visibilidade da interface denota uma proposição, uma intencionalidade: o fato de inserir sons em um dado contexto pode fazer pressupor que deve existir algum tipo de relacionamento entre eles. 


\section{Reações do público}

Para coleta de impressões do público foram escolhidos três procedimentos, já citados previamente: registro de vídeo com câmera estática e em movimento, registro fotográfico, e entrevistas semi-estruturadas. Tratando-se de uma intervenção, as entrevistas semiestruturadas convergem com os interesses do experimento e da pesquisa por ser uma forma de reunir diversas interpretações e compreensões dos entrevistados, ao mesmo tempo que permite ao entrevistador aprofundar descrições ou reflexões espontâneas do entrevistado e também inserir o contexto do CDHU para estimular reflexões a respeito.

Algumas pessoas aproximaram-se do local da praça onde os pesquisadores estavam reunidos procurando por maiores referências sobre a intervenção, fazendo perguntas e procurando informações se haveria algum caráter de reivindicação ou manifestação política por parte dos pesquisadores. Outras, após tomar conhecimento da intervenção, buscavam até mesmo elaborar alguma análise ou crítica sobre a intervenção e a presença dos pesquisadores, em conversas com os mesmos. Através da observação in loco e 132 análise do material de registro, foi possível observar pessoas em grupos se comunicando, e alterando suas atitudes umas com as outras por causa do som reproduzido.

Como já mencionado, na parte da manhã foi realizado um teste da intervenção, reproduzindo-se o som do trem sem edição, ou seja, tal qual ele foi captado, e à tarde, foi reproduzido o som do trem editado. 

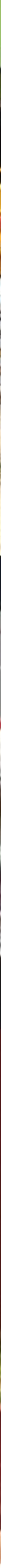


\section{Quanto às relações de escuta}

“Até estranhei né, tava vindo aqui eu olhei... aquele lá falou 'vem lá do mercadão', eu falei 'não, não vem do mercadão não, eu acho que era do trem pra lá [na estação]'."

A relação entre visão e audição aparece muito intrínseca nas reações, tanto nas entrevistas quanto na observação dos vídeos. Nas entrevistas, essa relação aparece de maneira verbalizada e muito espontânea, às vezes um lapso, como no comentário acima.

Retomando o conceito de escuta referencial formulado por Katharine Norman (1996) e discutido no primeiro capítulo dessa dissertação, esse modo de escuta se dá quando se procura a correspondência visual da escuta, e isso trata da tentativa de relacionar a experiência sonora à realidade temporal.

A escuta referencial busca a conexão entre som e fonte sonora, tratando de uma forma de suplementar a audição através da visão, buscando relações diretas entre causa e efeito. $\mathrm{Na}$ intervenção, contudo, a escuta referencial não encontra correspondência direta com a visão: ao invés do trem encontram-se as caixas de som, ao invés da ferrovia há a praça.

"É, fiquei procurando, porque não tem trem por aqui."

“Não acho ruim não, só fiquei procurando, eu falei ‘nossa, gente, barulho de trem, onde tem trem aqui?"'

Todavia, pela troca de contexto oferecida pela interface, alguns relatos, imagens e vídeos de registro denotam que a procura pela origem do som é também uma busca de referência espacial. Isso não ocorre no sentido da perda de referência do local onde se está, e sim na busca de dinâmicas que estão acontecendo no local para justificar o som, dada sua falta de contexto.

Muitas respostas à pergunta "O que você acha da praça com esse som?" foram vagas ou meramente adjetivas, estabelecendo dualidades. Foram utilizadas palavras que indicam opiniões diversas, por vezes derivadas: "barulhento", "legal", "incômodo", "interessante", "diferente", "ruim", "bom", "estranho". 
Percebeu-se dificuldade nos entrevistados em elaborar uma reflexão sobre a relação entre som e espaço, principalmente por se tratar de uma pergunta densa: ainda que simplificada, a pergunta teve caráter abstrato. Isso pode se reforçar a partir de uma dificuldade em descrever sons qualitativamente. Contudo, alguns entrevistados responderam à pergunta tanto com base no contexto imediato, da praça, quanto de seu próprio conhecimento e experiência anteriores.

“Achei legal. Na verdade, eu moro longe, moro em Santos, então pra mim tinha mesmo aqui um trem passando por aqui, eu não sabia que não era o som de um trem de verdade, daí eu vi a caixa de som, daí eu falei 'nossa!'."

"Meio... esquisito né? Parece que o trem realmente vai chegar. Estranho, muito estranho"

"É Diferente.
$P$ - O que você pensa disso?

Então, se fosse todo dia, deve ser bem chato. Eu não vejo muita diferença porque perto de casa, por exemplo, passa o trem e o som é pior todo dia. Só estranhei porque é aqui no centro."

É necessário ressaltar que não havia nenhum outro fator além das caixas de som que incitasse as pessoas a virarem a cabeça em direção à fachada do Mercado Municipal, onde se localizavam as caixas de som.

$\mathrm{Na}$ intervenção, o processo de escuta das pessoas possui o trem como um elemento que estimula o processo de troca de foco e atenção. O público se depara com uma outra situação sonora, e, para identificar que se ouve e o porquê de ouvir os sons do trem, incomuns àquele local, precisa dar início a um processo de escuta mais atenta e engajada. O som do trem, enquanto elemento representativo de algo, desperta a escuta como uma prática ativa, em que "perceber, ouvir, experienciar e pensar são ações altamente participativas e interativas ${ }^{15 "}$ (RUDI, 2005). Reações das pessoas são possíveis

\footnotetext{
15 Tradução nossa. "perception, listening, experiencing and thinking are highly interactive and participatory actions."
} 
de serem identificadas não somente através dos olhares direcionados às caixas de som, mas também na reação que grupos de pessoas tiveram entre si. Algumas pessoas realizaram brincadeiras, empurrando uns aos outros, fazendo referência à reprodução, como se tivessem próximos à uma linha de trem. Esses grupos, em especial, demonstram um caráter de imaginação em relação ao espaço, de que o trem estaria passando pela praça.

Em outros grupos, pôde-se perceber que as pessoas começaram a se entreolhar, rindo, para então direcionar o olhar às caixas de som; outros se entreolhavam e apontavam para as caixas de som. Essas atitudes demonstram que o processo de escuta ocasionado pela intervenção causou mudanças nas relações entre alguns grupos, também respondendo ao som com suas atitudes.

Alguns comentários demonstram uma associação entre o contexto da praça do mercado e a relação que as pessoas têm com sua moradia, o que caracteriza o papel da interface enquanto espelho (BOLTER; GROMALA, 2003): nesses casos, o entrevistado faz uma referência direta ao seu próprio contexto, pois mora próximo da ferrovia ou em algum local de onde é possível ouvir a passagem do trem.

Por outro lado, é notável, em algumas falas, o estranhamento, muitas vezes em função da diferença de contextos. Tratando os sons do trem de forma qualitativa e promovendo estranhamentos que denotam uma diferença em relação ao entorno sonoro acústico, a intervenção levou os ouvintes a questionarem esses contextos. Dessa forma, a reprodução traz à tona uma questão que é comum a vários habitantes da cidade: insere aspectos que se relacionam à rotina cotidiana de muitos através da diferenciação do entorno sonoro acústico do contexto da praça, oferecendo o som do trem como um ponto convergente que incita variadas discussões e reflexões, externalizadas ou não. 


\section{Além do som: o som como elemento representativo}

Nas entrevistas, é possível identificar correlação do som do trem com o local de moradia de entrevistados que moram próximos à linha férrea. Não somente aspectos sonoros são relacionados, como também conseqüências físicas dadas pela passagem do trem através de fenômenos como ressonância. Nas entrevistas, a casa foi referida como um local de onde se espera "paz", "sossego", associada por outros também a atividades como dormir e descanso. Os sons do trem por vezes foram postos como antítese à paz e sossego, como é aparente no relato:

"Meio irritante [riso contido] pra falar a verdade né. Eu não gosto de barulho não, eu gosto de um pouco mais de paz"

A vibração física também é colocada como uma forma de perturbação muito forte. Um dos entrevistados, que veio espontaneamente conversar com os pesquisadores, relata:

"Perto da minha casa, eles param. Quando ele pára, ele solta o freio, parece que o trem vai tombar em cima da casa. [...]

$P$ - E qual que é a distância entre sua casa e os trilhos? A rua e a casa, somente. Tem a calçada, a rua e já é a casa. [...] De noite assim, quando tô assistindo televisão, começa a chacoalhar a casa.

Chacoalha bem. E depois que dorme eu não sei."

Outros comentários também deixam transparecer a questão da influência do som no espaço físico sob a forma de ressonância, sugerindo que passagem do trem comprometesse a sensação de segurança e da proteção da casa.

“Barulho né, na cabeça. Falta de paz e sossego.[...] Eu moro perto [da linha férrea], o trem chacoalha minha janela, chacoalha todas as minhas janelas."

"É ruim né. Porque eu já morei num lugar também que o trem passava. A gente tava dormindo, nossa!, acordava, pensava que a casa ia cair. Lá em Pernambuco. [...] Eu nunca acostumei não, passei sete anos nesse 
lugar, não acostumei não."

“Locomotiva né... eu tremia... Gente mora lá, eu sei que é insuportável”

Comentários determinam que a ressonância associada à passagem do trem confere uma sensação de instabilidade devido ao tremor, por consequência, a sensação de insegurança.

Ao mesmo tempo, em contraponto, poucas pessoas acham que morar próximo à linha férrea é uma experiência prazerosa, transparecendo certa nostalgia. Esses depoimentos foram dados por um homem, de aproximadamente 30 anos e uma mulher de aproximadamente 65 anos, respectivamente:

$$
\text { "P - o que você achou da praça com o som do trem? }
$$

Cada um tem um modo né. Eu acho bacana, eu gosto. Inclusive eu morei ali na Vila Prado [bairro residencial próximo à ferrovia], ali, praticamente 19, 20 anos, nascido e criado ali. Então eu brincava na linha do trem. Então de casa dava pra ouvir perfeitamente o barulho desse trem. [...] Eu sempre gostei, sei lá."

$$
\text { "P - O que a senhora acha da praça com o som do trem? }
$$

Gosto. Me lembra eu. [...] Morei dez anos desse jeito, filho... dez anos.

$P$ - E como que era para a senhora?

Era muito bom. Bom demais."

Nesses dois casos, tem-se o som do trem como evocativo de um momento na vida dessas pessoas, as quais possuem afeto e memórias positivas, que transparecem no discurso. Contudo, quando não houve referência direta à ferrovia ou ao trem, resta a incerteza se a memória positiva tem uma correspondência direta com o trem ou com um momento bom na vida dessa pessoa, como por exemplo no segundo relato acima.

Salome Voegelin (2010) afirma que o som se apresenta como um "gatilho patético" [pathetic trigger]. "Patético" se refere ao termo "falácia patética", de Ruskin ${ }^{16}$. o "patético"

\footnotetext{
16 John Ruskin foi escritor e crítico de arte inglês do século XIX, e cunhou o referido termo para dizer respeito da falsidade das impressões sobre as coisas externas através da atribuição de qualidades humanas a coisas ou seres não humanos (RUSKIN, 1903, p.166183 apud VOEGELIN, 2010, p. 177)
} 
denota "sensação forte ou violenta" (Idem, p. 177), e o som como um "gatilho patético" refere-se à ação afetiva do som sobre o ouvinte. Para Voegelin (Ibid.), o som possui possibilidades imaginativas; é através dessas ações afetivas que o som desencadeia o engajamento.

Esse fator também pode ser relacionado à escuta contextual, nos termos de Katharine Norman (NORMAN, 1996), que une tanto a escuta referencial quanto a reflexiva, que se refere ao significado conceitual dos sons através de associações particulares e pessoais. A escuta contextual é a avaliação do som dada pelo ouvinte de acordo com seu contexto, onde som e contexto são inter-relacionados e avaliados. Pertencendo ao âmbito referencial e reflexivo, os contextos da história individual influenciam a imaginação sobre o som e seus significados.

O som, através da troca de contextos, abre possibilidades do ouvinte relacionar o som às experiências vividas, aos "símbolos apreendidos" (NORMAN, 1996) onde o material e o contexto são interrelacionados e avaliados.

Apesar de o som do trem reproduzido na intervenção não assemelhar-se a sons gravados em formatos fonográficos antigos, nem parecer ser um som de trem antigo, alguns entrevistados fizeram referências diretas a experiências passadas, como se o trem fizesse parte apenas desse contexto temporal. Reconhecendo a memória afetiva como parte do processo de escuta (VOEGELIN, 2010, p. 185), o som do trem se constituiu, para esses entrevistados, como um gatilho patético. Dessa forma, a qualidade subjetiva e afetiva da memória motiva o engajamento da escuta.

“- Sabe o que era bonito? A... A Maria Fumaça, antigamente né.

- Fazia esse som?

- Não, não fazia esse som. Ela, ela vinha de Dourado, passava em Trabijú, São Carlos, não passava em Araraquara, vinha por aqui. E a gente vinha, tinha uma serrinha pra gente passar. Nossa... a gente chorava de dar risada. E de medo também, né, que tinha a serra, você olhava pra baixo era a serra."

“Eu vim de Dourado, Ribeirão Bonito, eu tinha 16 anos. Eu tenho... amanhã eu vou fazer 69. Olha quantos anos que eu moro aqui em São Carlos! Aí foi uma novidade, meu filho falou assim pra mim 'será que é o trem que tá 
passando por aí?' [risos] Por isso que eu falei para você 'ô moço, cuidado com o trem!"'

"É uma novidade. Na hora que eu ouvi, eu parei e eu fiquei imaginando, daí deu aquela saudade."

Outras experiências e associações, diferentes das aqui citadas, foram mencionadas por entrevistados de forma muito pontual:

"Não sei se é porque eu gosto de música, toco bateria, tenho banda... Sei lá, mas eu gosto. Principalmente aquele barulho ta-tá ta-tá, aqueles toques que dá no trilho"

Nesse relato, pode-se observar que o entrevistado identifica o som como resultante de variadas ações e fontes sonoras, que dão origem à totalidade do conjunto dos sons do trem. Assim, o entrevistado dividiu esse conjunto de sons, considerando além da buzina, lembrada por outros entrevistados. Além disso, ele demonstra a propriedade rítmica do trem contida nessa fração de seu conjunto. Sua reflexão tange musicalização de sons, indicando o desenvolvimento de seu modo de escuta.

"Cara, coisa engraçada, né. Eu tive agora pouco aqui. E eu tava e vendo assim, toda a movimentação... eu falei, puxa, é engraçado que você fica procurando né. Acabou parecendo uma estação mesmo: a movimentação, o povo sentado, uma coisa meio engraçada, uma coisa meio diferente. Foi estranho, foi legal"

Nesse relato o entrevistado indica que tomou também a posição de observador para produzir uma reflexão. Além de notar aspectos da escuta referencial em outras pessoas, não se limitou em apenas pensar a ação do som na praça: o entrevistado criou um terceiro entorno imaginado a partir da justaposição de entornos sonoros, considerando também locomoção e a dinâmica das pessoas presentes. O entrevistado faz correlações entre esse entorno imaginado e o entorno sonoro e físico da praça. O entorno sonoro reproduzido, justaposto ao entorno físico, alterou o entendimento do entrevistado sobre aquele instante, acarretando em aproximações do que acontecia na praça ao seu processo imaginativo. 


\section{No ouvido do outro: a questão do CDHU}

O relocamento se caracteriza como uma tentativa de trazer as pessoas da Praça do Mercado à posição do outro através da aproximação de contextos, através do conjunto sonoro do trem. Há uma aproximação de olhares que, ainda sendo de uma só via, pode despertar maior empatia ou entendimento sobre o outro. Como discutido previamente, trata-se da conexão das pessoas presentes na praça com uma problemática remota, um campo promovido através da atuação da interface. Trata-se de transferir um ponto de escuta de uma população que mora próxima à ferrovia para uma outra que, às vezes, desconsiderava essa realidade por ser distinta.

Os sons do trem do CDHU, bem como a problemática trazida pela ferrovia estar muito próxima ao conjunto, foi colocada em pauta na intervenção através das entrevistas semiestruturadas. Considerou-se que a especificação do local seria difícil de ser trazida de maneira clara na intervenção somente pelos elementos sonoros do trem desse local, pois o trajeto da ferrovia perpassa variados bairros de São Carlos, além de haver também a consideração da possibilidade das pessoas desconhecerem o CDHU. Dessa forma, as entrevistas e os folhetos distribuídos durante a intervenção colaboraram para essa especificação, informando o público.

Em entrevistas realizadas no $\mathrm{CDHU}$, os entrevistados dizem que geralmente $\mathrm{o}$ trem buzina constantemente quando passa pelo CDHU e sua passagem ocasiona rachaduras nos apartamentos. Algumas vezes, o trem chega a parar e bloquear, durante longos períodos de tempo, a passagem do cruzamento, impedindo o acesso do CDHU a outros bairros, seja por veículos ou a pé. Segundo uma moradora, nesses casos alguns pedestres se arriscam. A circulação de trens tem fluxo intenso, como pôde ser observado durante a soundwalk, o que também reflete a conclusão do IPEA (2013) de que a ferrovia está operando no limite de sua capacidade, mencionada nesse capítulo. O cruzamento possui um histórico de vários acidentes, envolvendo carros, motos, inclusive de casos de suicídio.

Contudo, diante do panorama exposto pela pergunta "Esse som foi gravado no CDHU, onde o trem passa várias vezes durante o dia e durante a noite, o ano todo, e moram quase mil famílias. O que você acha disso?", a maioria das pessoas demonstravam certa empatia, alguns se imaginando na posição do outro, outros com comentários pontuais que 
se demonstravam superficiais: "é ruim", "deve incomodar", "deve ser meio perturbante". Outros comentários demonstravam preocupação relativa à segurança de crianças e ao conforto de idosos, identificando esses grupos como mais vulneráveis à ação do trem.

"Nossa, direto [dia e noite]? Se eu morasse lá não ia gostar, criança pequena, idosos, acho que não seria legal."

Houve a diferença de postura de alguns entrevistados quando era feita a pergunta sobre o $\mathrm{CDHU}$, pelo seu caráter informativo. Ao saberem desse contexto do CDHU em relação à ferrovia, a primeira reação dos entrevistados se refere também ao que acabaram de experienciar através do conjunto de elementos sonoros dos sons.

Enquanto que no CDHU o trem passa de duas em duas horas, aproximadamente, a intervenção promoveu uma regularidade mais intensa em intervalos de tempo menores. Assim, a intervenção condensa esse contexto, em um espaço de tempo muito menor, utilizando somente o som. Muitos entrevistados, após a pergunta sobre o CDHU, remeteram à uma experiência pessoal, fazendo relações e contando sobre seu local de moradia.

Outros comentários nas entrevistas podem também ser considerados indiferentes, ou seja, com o entrevistado excluindo-se desse contexto através de comentários como "mas é só quem mora lá perto". Outros entrevistados realizaram comentários com posicionamento político:

"Eu sou a favor totalmente de tirar o trem por questões de segurança, por questões de conforto. Por várias questões. Acho que o trem deveria passar por fora, ou deveria ter um uso na cidade, não tem nenhum uso pra gente. Acho bem errado o trem passar no conjunto habitacional"

"Não sei como te falar. Eu acho que pra começar não deviam ter feito o loteamento se eles sabiam que o trem passava lá, porque o trem tá lá faz quantos anos?" Os comentários sobre o trajeto da ferrovia questionam a sua pertinência, considerando os problemas que a ferrovia traz sem aparentemente oferecer à população nada em troca. Outros comentários discorrem sobre a necessidade de sua modernização, tanto da frota quanto da reconsideração do trajeto. Observa-se nesses comentários a reflexão sobre 
alternativas de desenvolvimento urbano, seja quanto à transposição da ferrovia ou através do questionamento da expansão urbana.

Segundo uma moradora do $\mathrm{CDHU}$, ao reclamarem à empresa de transportes sobre 0 disparo sucessivo de buzinas na região do $\mathrm{CDHU}$, a resposta da empresa foi que era a ordem dada aos maquinistas em virtude de vários acidentes relacionados ao cruzamento e também no trajeto da ferrovia como um todo. Contudo, a moradora diz que, após passarem pelo cruzamento, os trens continuam buzinando, por todo o trajeto.

O som demarcado da buzina, bem como os efeitos físicos que se dão pela passagem do trem, são colocados juntos com a interrupção da circulação de veículos e de pedestres como problemas maiores relacionados à ferrovia.

\section{Considerações}

O método soundwalk foi útil por facilitar uma rápida e, para os objetivos do experimento, suficientemente aprofundada compreensão do entorno sonoro dos dois locais. Essa estratégia, além de auxiliar também a observação das dinâmicas inscritas nos locais, adiciona processos de gravação sob os quais a interface se estrutura.

Na Praça do Mercado, foi importante apreender não somente o entorno sonoro, mas também algumas dinâmicas sociais inscritas nesse espaço. A apropriação da praça é principalmente pelo movimento.

O facto de se assinalarem esses locais com elementos de carácter permanente pode contribuir para indicar os tipos de ocupação que existem na cidade e criar um meio-ambiente que não seja fluido e monótono, mas sim estático e ocupado (CULLEN, 1983, p.25)

Pôde ser observado que a praça carece de equipamentos públicos que propiciem o uso daquele local pelas pessoas, seja protegendo-as do calor do sol através da criação de zonas sombreadas ou de mobiliário urbano que convide à permanência, propiciando outros usos do espaço para além da simples passagem. Os bancos que estão sob a copa de árvores, na maioria das vezes, são todos ocupados por pessoas em grupos, de 
variadas faixas etárias. Esses bancos, por estarem em locais de sombra, contudo, parecem locais de eleição, devido à falta de outras opções com sombra.

Observou-se que a praça possui potencial para sua utilização para sociabilidade e lazer, dada sua localização, uso da área comercial e comunicabilidade com lojas do comércio e outros serviços, ainda que seu entorno sonoro possua alta intensidade do som com origem, principalmente, no tráfego de veículos.

A consideração do entorno sonoro intenso da Praça do Mercado, tornando necessária proximidade com a fonte sonora, foi importante para o planejamento da intervenção. A influência do som sobre outro local seria diferente, dependendo das características do entorno. Na praça do Mercado, durante essa primeira etapa do experimento, concluiu-se que seria necessária alta potência de som para conseguir propagá-lo na praça, de maneira que remetesse à passagem de um trem.

As visitas ao CDHU foram úteis também para entender melhor o efeito da ferrovia sobre o conjunto através da observação. Assim, foi possível reiterar a afirmação de estudos anteriores realizados pelo Nomads.usp que a praça da Mangueira constitui um local de uso comum para os habitantes do conjunto, conferindo um local de encontro (DIAS, 2013). Apesar disso, foi possível também observar o uso da rua Prof. Francisco Sampaio por crianças brincando, defronte à linha do trem e com pouco tráfego.

Além disso, foi feito contato informal e espontâneo com alguns moradores e prestadores de serviço da região, curiosos com nossa presença portando equipamentos de gravação. Ao dizer-Ihes que se procurava entender como o trem afeta o local, surgiam relatos pessoais e espontâneos, principalmente sobre a interdição temporária pelo trem na passagem do cruzamento.

Uma dessas conversas informais foi com um menino de aproximadamente 12 anos, morador do condomínio 3. O menino, após ouvir com o fone de ouvido o som captado pelo microfone, teve interesse em ajudar a gravar o som do trem, além de sugerir outros sons para serem gravados, vocalizando-os para demonstrar quais aspectos dos sons sugeridos ele gostava. Esses sons eram provenientes de caminhões sem carga, que passavam pela linha do trem fazendo estrondo metálico, canto de pássaros, e as frequências agudas dadas pelos freios dos ônibus. Isso motivou reflexões para a pesquisa, pelo fato de 0 menino não fazer referência nenhuma à palavra "barulho" e por demonstrar alto interesse por sons de origem mecânica, que não são considerados agradáveis de maneira geral. 
Por outro lado, a marginalização do CDHU pelo restante da cidade também pôde ser observada durante essas visitas, demonstrada através de uma pessoa que, espontaneamente, parou para conversar e alertar que aquele local era perigoso, e que alguém poderia roubar os equipamentos.

Através dessa primeira etapa, tornou-se ainda mais claro que a presença do pesquisador não é neutra. Percebia-se que a presença do pesquisador como algo não corriqueiro. A interferência de outras pessoas foi maior no $\mathrm{CDHU}$, sendo que na Praça do Mercado apenas uma pessoa se aproximou para conversar. Contudo, essa interferência é entendida, dentro desse contexto, como altamente produtiva em termos de pesquisa, pois as conversas informais auxiliaram maior entendimento sobre o local.

A intervenção como um todo, além estar inscrita no experimento que promove o aporte prático à pesquisa, contribui também para surgimento de reflexões das pessoas que utilizam a praça do Mercado, pois promove um locus comunicativo. Sua importância reside no convite à reflexão que ela faz às pessoas que estavam na praça, obtendo impressões diferentes quanto ao som do trem relocado, e também estabelecendo contato dessas pessoas a um outro contexto que pode refletir o seu próprio.

Assim como as intervenções analisadas no capítulo anterior dessa dissertação, a interface estrutura e dialoga com a proposição da intervenção Reverberação Urbana. Os processos estabelecidos pela interface, junto à visibilidade dos equipamentos, denotam o relocamento, a transposição de sons de outra localidade junto a uma intenção.

Em intervenções em espaços públicos, de maneira geral, há menor controle na abordagem dos pesquisadores ao público e existem dificuldades quanto a formas de coleta por não haver restrição e controle de entrada e saída em espaços públicos, as pessoas podem ir e vir. O controle de entrada e saída é útil por possibilitar a organização das visitas do público e abordá-lo de forma mais estruturada, contudo não promove diversidade de entrevistados. Há também dificuldades de se obter informações qualitativas do público, o qual muitas vezes não é frequentador assíduo do local e se vê surpreendido quando é abordado pelo pesquisador. Da mesma forma, impressões ou reflexões subjetivas das pessoas que participaram da intervenção podem surgir após sua realização.

Tais dificuldades devem ser contornadas da melhor maneira possível para a realização de análises, bem como reflexão acadêmica. Para tanto, não se trata da invenção de novos 
métodos de pesquisa e sim da escolha e possível adaptação de métodos existentes para abordar melhor questões de pesquisa.

Verifica-se nos procedimentos metodológicos do experimento a utilidade tanto em uma pesquisa acadêmica quanto em atividades ligadas ao campo das intervenções e da arte. Avaliações dessa natureza sobre essas intervenções são extremamente necessárias, não somente para o aprimoramento de trabalhos futuros, como também para que se construam entendimentos sobre relações entre pessoas e sua maneira de utilizar espaços públicos urbanos, ou identificar opiniões e interpretações diversas sobre questões determinadas pelo pesquisador ou realizador. Verifica-se também, nesse tipo de experimento, uma potencialidade para que pesquisadores de variados campos disciplinares, tais como Urbanismo, Ciências Sociais, Serviço Social, Música, dentre outros, coletem informações qualitativas sobre variadas temáticas, alterando o uso da interface e dos elementos sonoros de acordo com os objetivos de pesquisa.

Na intervenção Reverberação Urbana os métodos de registros se mostraram de maneira eficaz. Apesar da cidade de São Carlos não costumar receber intervenções desse tipo em seus espaços públicos, a receptividade por parte da população participante foi considerada boa.

O uso de registros em câmera estática e móvel, com a câmera sendo operada por pesquisador, mostrou-se muito importante pelo fato de um registro complementar o outro. A câmera estática promove determinada imparcialidade, privilegiando um plano geral porém com menor aproximação das pessoas. Há, portanto, menos detalhes. Essa deficiência foi suprida através do uso da câmera móvel e dos registros fotográficos dos pesquisadores, com olhar mais direcionado mas que conseguia captar maiores detalhes.

É possível encontrar pontos em comum entre todos os depoimentos das pessoas, porém estabelecem adjetivos antagônicos quando se expressam em relação ao som do trem. Apesar dos entrevistadores se referirem ao "som" do trem, muitos entrevistados diziam "barulho". Esse fato é dúbio, pois "barulho" pode ser considerado uma forma coloquial de se chamar um som, porém possui em si um sentido de som desagradável, desorganizado, por vezes um ruído. Nenhum entrevistado, inclusive os que qualificaram negativamente o som na praça, nomeou diretamente o som como um ruído, mas muitos fizeram referências adjetivas, como "barulhento", ou dizendo que "ïncomoda". 
Referir-se a algum som como "barulho" pode denotar como algo que não é agradável, tido como inevitável. Contudo considera-se que, mesmo em depoimentos que conferiram aspectos negativos ao som do trem, houve a proposição de um campo de reflexão. Os sons do trem, adicionados a outro contexto e sendo recontextualizados, oferecem proposições de reflexão e retira a aleatoriedade.

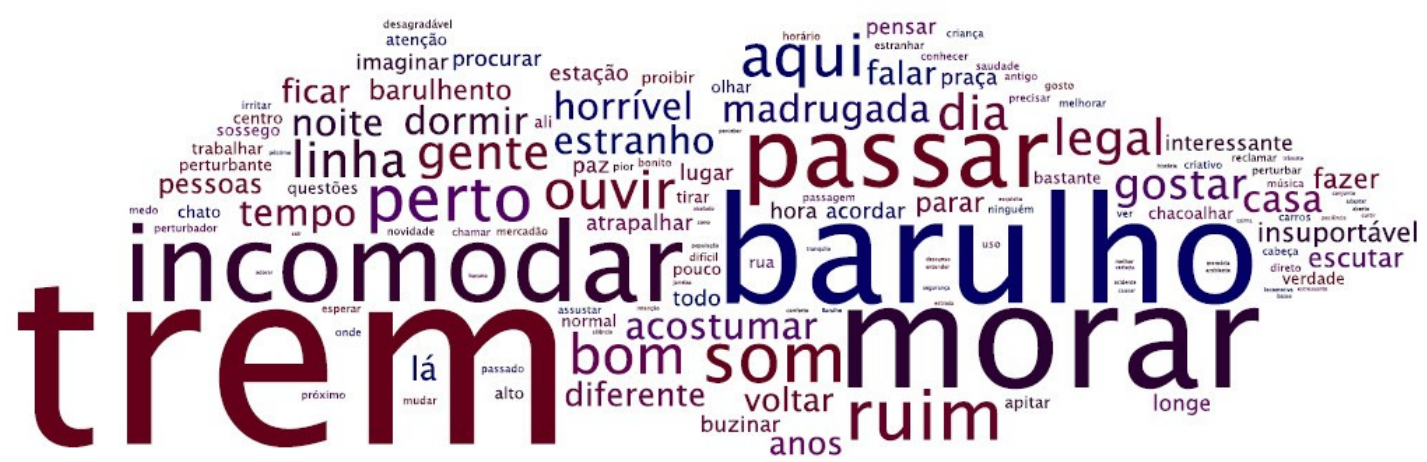

Trata-se de uma composição formada por som e espaço e, ainda que os sons relocados sejam considerados ruídos pelos entrevistados, esses adquirem valor representativo e se tornam significativos pela troca de contexto. Através da intervenção, estabelecem-se canais de comunicação, entre som e espaço, pessoas e contexto, seja o da intervenção ou proveniente de experiências pessoais. Pode-se reafirmar, então, que:

o aleatório, então, reencontra ordem. Qualquer ruído, quando duas pessoas decidem investir seu imaginário e desejo nele, torna-se uma relação potencial, futura ordem ${ }^{17}$ (ATTALI, 1985, p. 143).

Através do engajamento da escuta e também pela composição entre entornos sonoros, entorno físico e contexto das dinâmicas espaciais, é potencializado o efeito representativo do som, que se relaciona com experiências prévias do ouvinte, não necessariamente sonoras. A relação potencial é dada através do locus de comunicação estabelecido pela interface e das possibilidades de interpretação que, por sua vez, reafirma que a justaposição entre entorno sonoro e físico que oferece outro caráter sobre a apreensão do espaço.

\footnotetext{
${ }^{17}$ Tradução nossa. "The aleatory then rejoins order. Any noise, when two people decide to invest their imaginary and their desire in it, becomes a potential relationship, future order." 


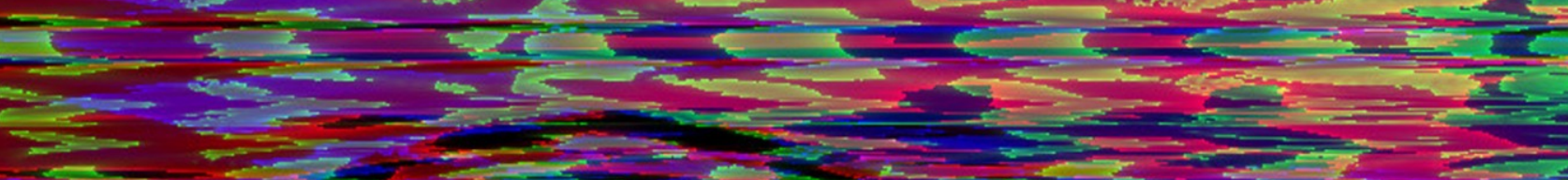

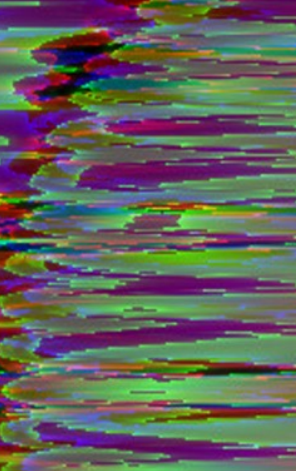

$=$

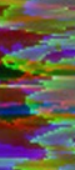

$$
=-\frac{1}{20}
$$

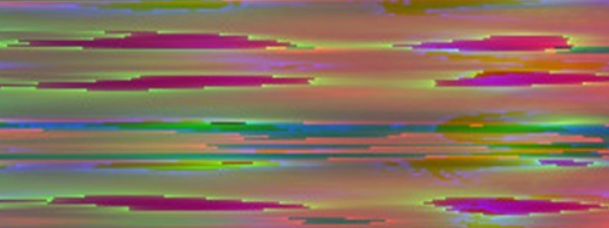

$\leq 5$

\section{$2+$}

$x_{x \rightarrow 2}$

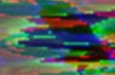

20

\section{Conclusões}

\section{Cong}

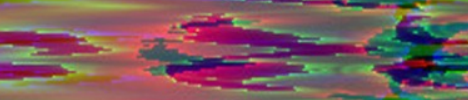




\section{Conclusões}

Através do aporte prático oferecido pelo experimento, há complementaridade dos conceitos teóricos, que auxilia o entendimento do som enquanto elemento do espaço: tanto por fenômenos físicos que estabelecem uma cadeia de influências entre som e espaço; quanto pela relação conversacional que esses dois elementos possuem, onde um influencia sobre a apreensão do outro. Assume-se que outros elementos, tais como os relacionados à visão, também modificam as apreensões do espaço, percepção assim como Pallasmaa (2005) e Edward Hall (1977) afirmam, ainda que sob perspectivas diferentes. Contudo, a investigação sobre o papel do som enquanto elemento do espaço parece pouco investigada, o que direcionou o presente estudo a procurar abordagens de diferentes campos disciplinares, realizando diálogos entre autores e diferentes áreas. Houve necessidade de realizar tais diálogos, devido esse campo específico ser pouco explorado. Esses diálogos são profícuos, contribuindo para o cumprimento dos objetivos. Contudo, durante o processo da pesquisa, houve dificuldade no estabelecimento de correlações entre essas áreas, ora por possuírem terminologias diferentes, ora por se referirem a assuntos específicos ou realizarem abordagens fora do escopo da pesquisa, ou por não incluir o som em sua abordagem.

Nessas considerações finais, busca-se destacar alguns resultados desta pesquisa, apresentando uma síntese reflexiva do conteúdo dessa dissertação e do aprendizado obtido por esse processo de investigação. Para tanto, essas considerações finais estão organizadas em quatro tópicos temáticos: som e entornos sonoros; interfaces sonoras; som, espaço público e intervenções; e perspectivas futuras.

\section{Som e entorno sonoro}

Conforme discutido no primeiro capítulo, o som de maneira geral possui uma natureza ubíqua; em toda parte, o tempo todo, há sons. Não é possível isolar-se completamente 
dos sons, como é possível fechar os olhos para não ver. É possível afirmar que o silêncio absoluto existe somente na surdez fisiológica e na ausência de matéria. Portanto, o som é um elemento invisível, porém sempre presente.

A relação entre som e espaço mais direta e aparente é estabelecida por fenômenos físicos, através de propriedades acústicas do espaço que influenciam os sons. Contudo, também de uma maneira direta, o som é resultado das ações ocorridas no espaço físico, refletindo também características de organização social e modos de vida, através do estabelecimento de ciclos e ritmos.

A audição também é um sentido que atua na apreensão do espaço, conforme discutido durante os capítulos dessa dissertação. A audição pode configurar-se além de uma complementaridade da visão, indo além de seu sentido fisiológico, através de modos de escuta em que a atenção do ouvinte é direcionada ao som.

O entorno sonoro é constituído por elementos sonoros em conjunto, que são tanto sons oriundos de fontes sonoras de forma direta, quanto sons obtidos através de processos estabelecidos por interfaces, tais como gravação, reprodução, síntese, dentre outros, que geram construções sonoras abstratas. O entorno sonoro é, portanto, resultante de variados processos não devendo ser abordado como um único objeto, e sim como um conjunto que influencia o espaço e é também influenciado por ele, gerando uma relação conversacional e interdependente.

A justaposição entre entornos sonoros e entornos físicos sempre é presente na configuração do espaço, dado o caráter de ubiquidade do som. Contudo, o uso de interfaces promove outras situações, as quais reconfiguram essas combinações. Podem ser criados entornos híbridos: os variados processos que o áudio, o som transduzido, pode sofrer, são misturados ao entorno sonoro quando reproduzidos, e esse resultado se justapõe com o entorno físico.

O espaço é formado da interação inseparável entre instâncias físicas, movimentos e dinâmicas inscritas; fixos e fluxos, conforme Milton Santos (2001) afirma. Dessa forma, a intervenção Reverberação Urbana auxilia a compreensão desses aspectos, e é possível inferir que a intervenção proporcionaria um efeito diferente se realizada em outro local, pois tanto o espaço físico e suas dinâmicas quanto o entorno sonoro modificam o todo. Assim como a mesma configuração do mesmo espaço físico em duas comunidades distintas concorre para obter dinâmicas e usos distintos, não parece ser improvável que 
isso possa ocorrer também quanto ao entorno sonoro. Essa sugestão não se origina de um subjetivismo puro, mas sim ressalta esse caráter de interdependência entre esses dois elementos.

Os múltiplos pontos de vista obtidos pelo aporte prático da pesquisa, através da intervenção realizada, sugerem que a justaposição de entornos sonoros e físicos promove reconfigurações: a promoção de experiências sonoras, sob a forma de intervenção, auxilia a promoção de outros modos de escuta, os quais se dá redação uma escuta mais atenta. Trata-se de uma justaposição pois a prática não anula os entornos sonoros existentes nem se trata se uma simples adição, e sim resulta em um entorno híbrido que sugere outras interpretações e reflexões dados pelo som naquele dado contexto.

Sugere-se que a apreensão do conteúdo sonoro não é auto-suficiente, e se relaciona a uma cadeia complexa de experiências de vida e contextos que dão aos sons valor representativo, sendo difícil obter total imparcialidade e objetividade nesse processo, conforme é proposto por Schaeffer (1988) em relação à escuta reduzida.

\section{Interfaces sonoras}

No presente estudo, as interfaces não são apenas instrumentos tecnológicos, são formadoras de loci de comunicação. Elas colaboram para a hibridização de instâncias virtuais e físicas, tão comuns no cotidiano. Por isso, deve-se visar uma noção de interface que corresponda ao seu importante papel.

Assim como Zielinski (1997) afirma, interface não é um limite. Ao contrário, ela constitui um campo onde é permitido o contato, a relação entre um e o outro. Sua natureza pode ser semântica, atuando como uma "tradutora", possibilitando a conexão entre as partes e possibilitando o entendimento entre elas. Interfaces não constituem uma forma de eliminação de camadas, e sim, um meio de estabelecer interlocuções. Tendo em vista esse aspecto, interfaces estabelecem condições para gerar um locus comunicativo, onde partes se comunicam e trazem à tona o que não era antes tão notável, estimulando também a construção de compreensões e entendimentos. 
Interfaces sonoras ampliam a diversidade de entornos sonoros acessíveis ao ouvinte. A interface sonora também inscreve variados processos sob os quais os sons são submetidos.

\section{Som, espaço público e intervenções}

Nesse estudo, espaço não é considerado um invólucro delimitador, no qual objetos físicos e palpáveis estão contidos. Considera-se que o espaço é possuidor de caráter reflexivo e heterogêneo, possui tanto instâncias físicas quanto dinâmicas sociais e culturais. Portanto, o uso de meios de comunicação e interfaces pode adensar o espaço arquitetônico através da hibridização entre instâncias virtuais e concretas (TRAMONTANO, 2007), o que concorre para sua reconfiguração. Sob essa perspectiva, trata-se de uma simbiose e não contraposição, adereço ou adição de instâncias virtuais e concretas. É nesse entorno híbrido que é possível se dispor diferentes loci comunicativos.

Através do uso de interfaces sonoras, intervenções podem trazer à tona características do espaço menos perceptíveis, estabelecendo um locus de comunicação e reflexão. O locus de comunicação promovido só se forma e é percebido através de seu uso. Contudo, suas ações estão limitadas à abrangência da escuta coletiva que elas oferecem.

As intervenções, do ponto de vista da pesquisa, possuem característica interdisciplinar e híbrida, tanto em relação aos tipos de interfaces que podem ser utilizadas, quanto às temáticas abordadas ou aos seus objetivos. Intervenções alteram ordens préestabelecidas nas dinâmicas de um dado espaço, sendo que a consideração das características anteriores à intervenção e de seu contexto podem ser produtivas, instaurando uma relação de correspondência. Trata-se de entender o espaço de sua atuação de uma forma ampla, para além de sua natureza física, considerando dinâmicas sociais, culturais, históricas, ambientais, dentre outras, estabelecendo relações conversacionais. As alterações que a intervenção promove sobre determinada situação do espaço podem também ser relevantes de um ponto de vista epistemológico; pois as intervenções podem auxiliar a criação de criando campos propícios para o 
questionamento dessas ordens pré-estabelecidas.

O espaço, dinâmico e heterogêneo, adensa em si instâncias virtuais, promovendo hibridização através do uso de meios de comunicação e interfaces. Dessa maneira, meios de comunicação e interfaces também influenciam o caráter público quando criam loci comunicativos.

Esses loci comunicativos possuem potencialidades de se abrigar assuntos compartilhados. O uso de interfaces em intervenções, que se utilizam de escuta coletiva em detrimento ao uso de fones de ouvido, tem potencialidade de oferecer algo em comum e compartilhado entre pessoas de grupos distintos, podendo formar também, para além da reflexão individual, canais de trocas e de expressões de ideias.

O público não se refere somente a locais físicos e sociais de interação, como afirma Castells (2008): o "público" também se refere à essência da comunicação que se dá em torno de um significado sócio-cultural em comum, de interesses e valores compartilhados, transcendendo o âmbito privado. O caráter público provém também das atividades, absorção e apropriação do espaço.

\section{Perspectivas futuras}

A presente pesquisa de mestrado aponta somente um caminho das possibilidades de abordagens do som enquanto elemento do espaço. Para futuras pesquisas, aponta-se a necessidade de se compreender mais sobre entornos sonoros segundo outras abordagens. Enfatiza-se a importância de se explorar diálogos possíveis entre teoria e prática em pesquisas sobre esse assunto em especial, pois é através desse processo que surgem outros problemas a serem elucidados pelo processo de investigação, os quais nem sempre são aparentes quando teoria e prática são tratados separadamente.

A importância de se produzir conhecimento a respeito de intervenções em espaços públicos e nas relações entre espaço e som reside em seu potencial de fomentar discussões e reflexões de assuntos de interesse público de determinada população, bem 
como incentivar apropriações do espaço público.

Contudo, é também necessária a utilização de métodos para coletar reflexões e interpretações dos participantes, seja em pesquisa acadêmica ou não, dado o valor social das intervenções. Dessa maneira, reforça-se o caráter da produção de conhecimento através dessas práticas.

Acredita-se que intervenções sonoras em espaços públicos não devem estar restritas somente ao âmbito da apreciação. De maneira geral, intervenções propõem, no espaço público, formas de reflexão sobre o próprio contexto do participante e sobre assuntos abordados por elas.

Por fim, uma das perspectivas de pesquisa também pode ser encontrada na investigação dos potenciais social e urbano das intervenções como um caminho que auxilia a manifestação e a apropriação do que é público, em oposição ao seu silenciamento. 


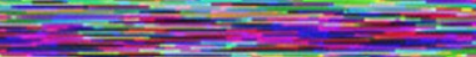

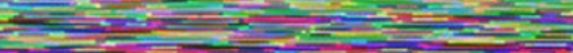

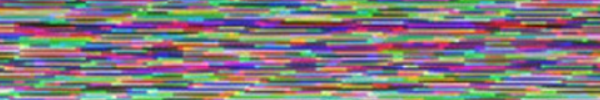

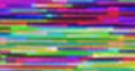

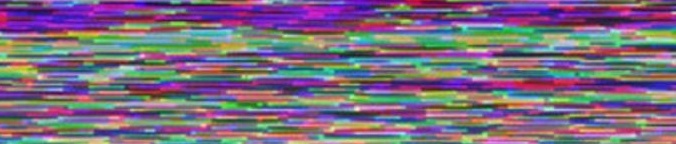

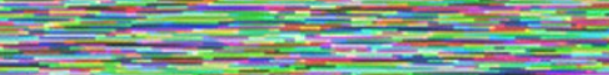

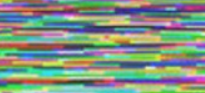

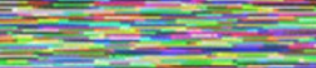

$2=$

$\frac{12}{2 ! 2}$

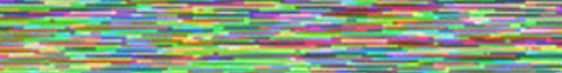

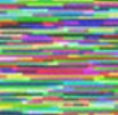

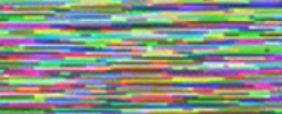

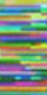
$=$

\section{$x^{2}$}

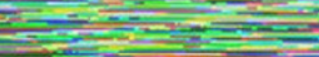

\section{들}

$5=$

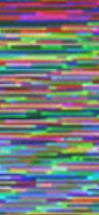

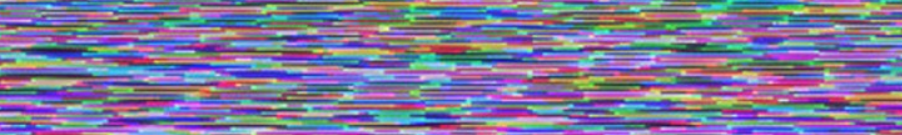

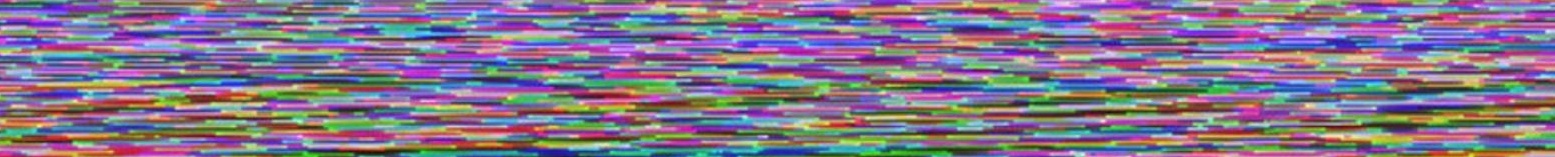
(n)

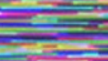

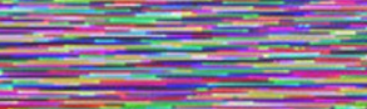
20

$\underline{2-20}$

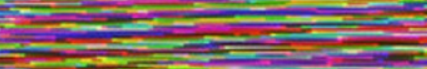

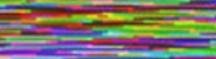

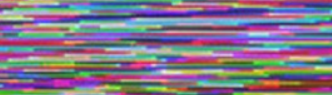

\section{Referénclas}

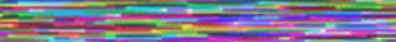

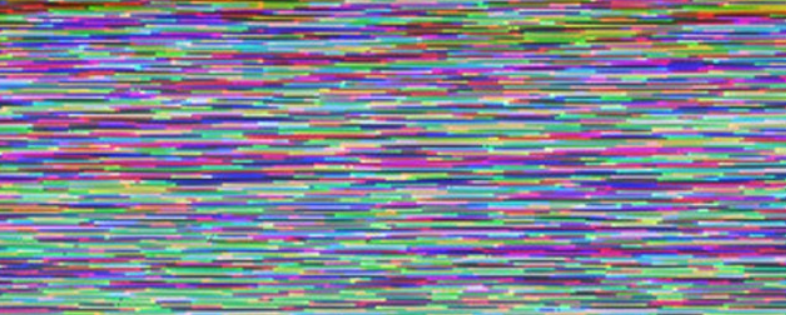

$=$

$=$

$x-2$

2

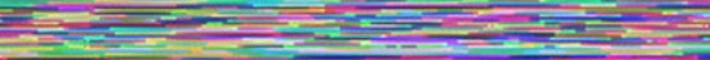

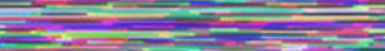

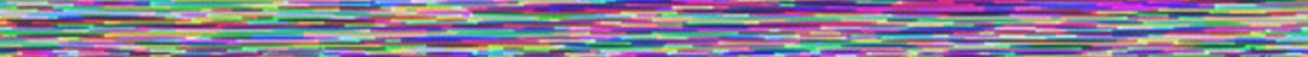




\section{Referências}

ADRIAANSENS, Alex; BROUWER, Joke. Alien Relationships from Public Space: A Winding Dialog with Rafael Lozano-Hemmer. Transurbanism, NAI Publishers, Rotterdam, 2002.

ALL-LOGISTICA. Site da transportadora. Disponível em <all-logistica.com>. Acesso em 22 dez. 2013.

ARANTES, Priscila. Arte e mídia. Perspectivas da estética digital. São Paulo: Senac, 2005.

ARENDT, Hannah. A Condição Humana. Rio de Janeiro: Forense Universitária, 2004

ARSELECTRONICA. Tiefdruckgebiet. A Heavylistening. Disponível em: <http://www.flickr.com/photos/arselectronica/7920434978/in/photostream/>. Acesso em 12 dez. 2013.

ATTALI, Jacques. Noise: the political economy of music. Minneapolis: University of Minnesota Press, 1985.

AUGOYARD, J.F.; TORGUE, H. Sonic Experience: a guide to everyday sounds. Montreal: McGill-Queen's University Press, 2006.

AUSTIN, Larry. Sound diffusion in composition and performance: an interview with Denis Smalley. Computer Music Journal, v. 24, n. 2, p. 10-21, 2000.

BULL, Michael. Sounding out the city: personal stereos and the management of everyday life. New York: Berg Oxford International Publishers, 2000.

BARTHES, Roland. Listening. In: BARTHES, Roland. Responsability of forms.Tradução Richard Howard. Berkeley, CA: University of Callifornia Press, 1985.

BRECHT, Bertolt. O rádio como aparato de comunicação. Discurso sobre a função do rádio. estudos avançados, v. 21, n. 60, p. 227-232, 2007. Disponível em < http://www.scielo.br/scielo.php?pid=S0103-40142007000200018\&script=sci_arttext>. Acesso em 13 jan. 2014. 
BOLTER, Jay David; GROMALA, Diane. Windows and mirrors: interaction design, digital art, and the myth of transparency. Cambridge: Massachusetts Institute of Technology Press, 2003.

CAGE, John. Silence. Middletown: Wesleyan University Press, 1961.

CASTELLS, Manuel. The New Public Sphere: Global Civil Society, Communication Networks, and Global Governance. The annals of American Academy, 616, Março 2008.

CHION, Michel. Audio-vision: sound on screen. New York Chichester: Columbia University Press, 1994.

COX, Chistopher. Sound Art and the Sonic Unconscious. Organised Sound, 14(1), 19-26, 2009.

CUFF, Dana. Immanent Domain: Pervasive computing and the public realm, Journal of Architectural Education, v. 57, n.1, 43-9, 2003.

CULLEN, Gordon. Paisagem urbana. São Paulo: Martins Fontes, 1983.

160 DAILY TOUS LES JOURS. Página sobre 21 balançoires no site do coletivo. Disponível em: < http://www.dailytouslesjours.com/project/21-balancoires/> . Acesso em: 28 out. 2012.

DANTO, A. Max Neuhaus: Sound Works, Nation. Março, 1991. Disponível em: <http://www.max-neuhaus.info/bibliography/Danto.pdf>. Acesso em 24 mai. 2013.

DIAS, Mayara S. Em Conjunto: ações culturais e meios digitais. 2013. 263p. Tese (Doutorado em Arquitetura e Urbanismo) - Instituto de Arquitetura e Urbanismo, Universidade de São Paulo, São Carlos, 2013.

DUARTE, Fábio. Crise das matrizes espaciais: arquitetura, cidades, geopolítica, tecnocultura. São Paulo: Fapesp, Editora Perspectiva, 2002.

DRUCKREY, Timothy. Relational Architecture: the Work of Rafael LozanoHemmer. Debates \& Credits. Media/Art/Public Domain. De Balie-Centre for Culture and Politics. Amsterdam, v. 2003, p. 69, 2003. Disponível em: < http://www.lozanohemmer.com/venice/pdFs/articles_panorama/02_Debates.pdf>. Acesso em 12 mai. 2013. 
EMMERSON, Simmon. Living Electronic Music.Hampshire: Ashgate Publishing Limited, 2007.

EMMERSON, Simmon. Location - Dislocation - Relocation ('Where is Live Electronic Music?'). In: IV Seminário de Música, Ciência e Tecnologia: Fronteiras e Rupturas, 2012, São Paulo Anais... São Paulo.

FERREIRA, Pedro Peixoto. Transe maquínico: quando som e movimento se encontram na música eletrônica de pista. Horiz. antropol., Porto Alegre, v. 14, n. 29, Junho 2008. Disponível em <http://www.scielo.br/scielo.php?script=sci_arttext\&pid=S010471832008000100008\&lng=en\&nrm=iso>. Acesso em 16 Abr. 2012. http://dx.doi.org/10.1590/S0104-71832008000100008.

FIRMINO, Rodrigo; DUARTE, Fábio. Manifestation and implications of an augmented urban life.International Review of Information Ethics, vol. 12, mar. 2010. Disponível em: <http://www.i-r-i-e.net/inhalt/012/012-full.pdf\#page=29 >. Acesso em 19 jul. 2012.

FIRMINO, Rodrigo; DUARTE, Fábio. Cidade infiltrada, espaço ampliado: as tecnologias de informação e comunicação e as representações das espacialidades contemporâneas. Arquitextos, ano 08 maio, 2008.2 Disponível em: <http://www.vitruvius.com.br/revistas/read/arquitextos/08.096/3408>. Acesso em 14 ago. 2013.

FIRMINO, R.; DUARTE, F.; ULTRAMARI, C. The Rising of the Ubiquitous City: Global Networks, Locative Media and Surveillance Technologies. In: FIRMINO, R.; DUARTE, F.; ULTRAMARI, C. (eds.). ICTs for mobile and ubiquitous urban infrastructures. Hershey: Information Science Reference, 2011.

FONTANA, Bill. Vídeo sobre Sound Island. ca. 1994. Disponível em: < http://echosounddesign.com/media/Paris.mov>. Acesso em 13 mai. 2013.

FOTH, M.; CHOI, J. H.; SATCHELL, C. Urban Informatics. In: Proceedings of the ACM 2011 conference on Computer supported cooperative work. ACM, 2011. p. 1-8.

FRASER, M. T. D.; GONDIM, S. M. G.. Da fala do outro ao texto negociado: discussões sobre a entrevista na pesquisa qualitativa. Paidéia, v. 14, n. 28, p. 139-152, 2004. Disponível em: <http://www.scielo.br/pdf/paideia/v14n28/04.pdf/>. Acesso em 14 jan. 2014. 
GARRIOCH, David. Sounds of the city: the soundscape of early modern European towns. Urban History, vol 30, pp 5-25, 2003.

HABERMAS, Jürgen. Mudança estrutural da esfera pública: investigações quanto a uma categoria da sociedade burguesa. Rio de Janeiro: Tempo Brasileiro, 1984.

HALL, Edward. A Dimensão Oculta. Tradução de Sônia Coutinho. Rio de Janeiro: Francisco Alves Editora, 1977.

HARGREAVES, D., MACDONALD, R. Designing Improvisation: Intercultural Collaboration and Musical Imagination, Procedia - Social and Behavioral Sciences, 45, p. 14-20, 2012. em: <http://www.sciencedirect.com/science/article/pii/S1877042812022744>. Acesso em: 22 abr. 2013.

HEAVYLISTENING. Site dos autores. Disponível em <heavylistening.com>. Acesso em 13 mai 2013a.

HEAVYLISTENING: Tiefdruckgebiet II (Linz Ars Electronica 2012). Tuftycom. Disponível em : https://www.youtube.com/watch?v=WmWYm7lhjWw> . Acesso em 13 mai 2013b.

HEINRICH, Jeff. 21-swing orchestra strikes a chord with user in Quartier des Spectacles. The Gazette, Montreal, 11 mai. 2011. Disponível em $<$ http://www.dailytouslesjours.com/wpcontent/uploads/2013/02/21B_Gazette_110511big2.jpg >. Acesso em 14 mai. 2013.

HOUAISS. Grande dicionário Houaiss da língua portuguesa. Disponível em: <houaiss.uol.com.br>. Acesso em 12 nov. 2013.

IAZZETTA, Fernando. Da escuta mediada à escuta criativa. Contemporânea Comunicação e Cultura, vol. 10, no. 1, jan-abr. 2012. Disponível em: <http://www.portalseer.ufba.br/index.php/contemporaneaposcom/article/view/5786>. Acesso em 24 set. 2012.

IPEA. Texto para discussão no. 1465: Gargalos e Demandas da Infraestrutura Ferroviária e os Investimentos do PAC: Mapeamento IPEA de Obras Ferroviárias. Disponível em: $<$ http://www.ipea.gov.br/agencia/images/stories/PDFs/TDs/td_1465.pdf>. Acesso em 12 dez. 2013. 
JACOBS, Jane. Morte e vida de grandes cidades. São Paulo: Martins Fontes, 2000.

JOHNSON, Steven. Cultura da interface: como o computador transforma nossa maneira de criar e comunicar. Rio de Janeiro: Zahar, 2001.

KAHN, Douglas. Noise, water, meat: a history of sound in the arts. Cambridge: MIT Press, 1999.

LABELLE, Brandon. Background noise: perspectives on sound art. New York: Continuum International Publishing, 2006.

LABELLE, Brandon. Acoustic Territories: Sound culture and everyday life. New York: Continuum Insternational Publishing, 2010.

LEAVY, Patricia. Method meets art: Arts-based research practice. Guilford Press, 2009.

LEFEBVRE, Henri. Rhythmanalisys: Space, time and everyday life. London: Continuum books, 2004.

LIMA, Renata Priore. O processo e o (des)controle da expansão urbana de São Carlos (1857-1977). 2007. 194p. Tese (Doutorado em Arquitetura e Urbanismo) - Escola de Engenharia de São Carlos, Universidade de São Paulo, São Carlos, 2007.

LYNCH, Kevin. A imagem da cidade. Tradução de Maria Cristina Tavares Afonso. São Paulo: Editora Martins Fontes, 1982.

LOZANO-HEMMER, Raphael. Voz Alta. Cidade do México, México, 2008. Disponível em <www. lozano-hemmer. com/english/projects/vozalta.htm>. Acesso 14 out. 2012.

MANOVICH, Lev. The language of new media. Cambridge: The MIT press, 2001.

MANOVICH, Lev. The poetics of urban media surfaces. First Monday, 2006. Disponível em <http://pear.accc.uic.edu/ojs/index.php/fm/article/view/1545/1460>. Acesso em 03 ago. 2013.

MENDES, C. F. Paisagem Urbana: uma mídia redescoberta. São Paulo: Editora Senac, 2006.

MEYROWITZ, Joshua. No sense of place: the impact of electronic media on social behavior. New York: Oxford University Press, 1985. 
MIYASAKA, Elza.; ANITELLI, Felipe.; PRADO, Mônica Faria de Almeida. Avaliação da qualidade do espaço interno em unidades habitacionais de interesse social. In: SIMPÓSIO BRASILEIRO DE QUALIDADE DO PROJETO NO AMBIENTE CONSTRUÍDO, 2009, São Carlos. Anais... São Carlos: Universidade de São Paulo, 2009. p . 666-677.

MITCHELL, William. Placing words: symbols, space, and the city. Cambridge, MA: Massachusetts Institute of Technology, 2005.

NEUHAUS, Max. Sound works, vol. I: Inscription. Ostfilldern: Cantz Verlag, 1994. Disponível em: <http://www.max-neuhaus.info/bibliography/WilliamDuckworth.htm>. Acesso em 24 mai. 2013.

NEUHAUS, Max. Excerpts from a conversation between Max Neuhaus and Gregory des Jardins. Disponível em: <http://www.maxneuhaus.info/soundworks/vectors/place/evocare/Evocare.pdf>. Acesso em 24 mai. 2013.

NIELSEN, Sabine. Níveis críticos da espacialidade: notas sobre uma intervenção artística na cidade de São Paulo. Revista do Instituto de Estudos Brasileiros, n. 56, p. 259-272, 2013.

NORMAN, Katherine. Real-world music as composed Listening. Contemporary Music Review, v.15, 1996. Disponível em: <http://www.novamara.com/KNpage/writingssound/NORMAN-CMR.pdf>. Acesso em 24 mai. 2013.

NOMADS.USP (Org.). Territórios Híbridos: Ações culturais, espaço public e meios digitais. São Carlos: IAUUSP, 2013.

NUNES, Fábio. O.; BRAZ, Soraya. Mobilidade, ausência e capas amarelas. V!RUS, São Carlos, $n$. 5, $2011 . \quad$ jun. Disponível em: <http://www.nomads.usp.br/virus/virus05/?sec=5\&item=1\&lang=pt>. Acesso em: 20 mar. 2012.

OBICl, Giuliano. A condição da escuta.São Paulo: Editora 7 letras e Fundação de Amparo à Pesquisa do Estado de São Paulo, 2008.

PALLASMAA, Juhani. Os olhos da pele: A arquitetura e os sentidos. $2^{\mathrm{a}}$ Ed. Porto Alegre: ArtMed Editora, 2005. 
PONZINI, M. Lozano-Hemmer: Relational Architecture. Digimag (Milano), n. 28, 2007. Disponível em <http://www.digicult.it/digimag/issue-028/rafael-lozano-hemmer-relationalarchitecture/>. Acesso em 04 jan. 2014.

PEIXOTO, Nelson Brissac. Intervenções Urbanas. In: PEIXOTO, N. B. (org.). Intervenções urbanas: Arte/cidade. São Paulo: Editora Senac, 1998.

RAIMBAULT, M.; DUBOIS, D. Urban Soundscapes: Experiences and Knowledge. Cities, v. 22, n. 5, p. 339-350, 2005.

RESOUNDINGS. The sound scultures and ideas of Bill Fontana. Site oficial de Bill Fontana. Disponível em: <resoundings.org>. Acesso em 12 mai. 2013.

ROEDERER, Juan. Introdução à Física e Psicofísica da Música. São Paulo: Editora da Universidade de São Paulo, 1998.

RUDI, Jøran. From a musical point of view, the world is musical at any given moment': an interview with Bill Fontana. Organised Sound, v. 10, n. 2, p. 97, 2005.

RUSSO, M.; WARNER, D. Rough Music, Futurism and Postpunk Industrial Noise Bands.

Discourse, v.10, n.1, p. 55-76, 1987. Disponível em:

<http://www.jstor.org/stable/41389097>. Acesso 12 jun. 2013.

SANTOS, Denise M. Espaços híbridos na cidade: interfaces computacionais para comunidades locais. 2008. 452p. Tese (Doutorado em Arquitetura e Urbanismo) Escola de Engenharia de São Carlos, Universidade de São Paulo, São Carlos, 2008.

SANTOS, Milton. A natureza do espaço. São Paulo: Hucitec, v. 1, 1996.

SASSEN, Saskia. Public Interventions: the shifting meaning of the urban condition. Open, no. 11, 2006. Disponível em: <http://classic.skor.nl/download.php?id=3232 >. Acesso em 26 out. 2012.

SCHAEFFER, Pierre. Tratado de los objetos musicales. Madrid: Alianza Música, 1988.

SCHAFER, Murray. A Afinação do mundo - uma exploração pioneira pela história passada e pelo atual estado do mais negligenciado aspecto do nosso ambiente: a paisagem sonora. São Paulo: Editora UNESP, 2001. 
SEMIDOR, Catherine. Listening to a city with the soundwalk method. Acta acustica united with acustica, v. 92, n. 6, p. 959-964, 2006.

SILVA, Adriana. From Cyber to Hybrid: Mobile technologies as interfaces of hybrid spaces. Space and Culture, 9(3), ago. 2006.

SMALLEY, Dennis. Space-form and the acousmatic image. Organized Sound, 12(1), 3558, 2007.

SOUTHWORTH, Michael. The sonic environment of cities. Environment and behavior, 1969.

STERNE, Jonathan. The audible past: Cultural Origins of Sound Reproduction. Duke University Press, 2003.

STERNE, Jonathan. Urban Media and the politics of Sound Space. Open, no. 9, $2005 \mathrm{~b}$. Disponível em: <http://www.skor.nl/_files/Files/OPEN!\%20Key\%20Texts_Sterne.pdf>. Acesso em 26 out. 2012.

TRAMONTANO, Marcelo. Interactive living spaces: 12 preliminary notes. In: Troyano (ed.) Installing: art and digital culture. Santiago, Chile: Lom, 2007.

TRAMONTANO, Marcelo; SANTOS, Denise M.; SOUZA, Mayara. Territórios Híbridos: 34 pontos para uma agenda de discusses. In: NOMADS.USP (Org.). Territórios Híbridos: Ações culturais, espaço public e meios digitais. São Carlos: IAUUSP, 2013.

TRUAX, Barry. Acoustic Communication. Westport: Ablex Publishing, 2001.

TRUZZI, Oswaldo Mário Serra. Café e indústria: São Carlos 1850-1950. São Carlos: EDUFSCar, 2000.

VENOT, Flora; SÉMIDOR, Catherine. The 'soundwalk' as an operational component for urban design. In: PLEA2006-The 23rd Conference on Passive and Low Energy Architecture. 2006. p. 6-8.

VOEGELIN, Salomé. Listening to noise and silence: towards a philosophy of sound art. New York: Continuum, 2010. 
VORONKOVA, Lilia; PACHENKOV, Oleg. Public Spaces in Modern Cities. Berkeley Planning Journal, $\quad$ v. 24, n. 1, 2011. Disponível em: <http://escholarship.org/uc/item/9jq565pw\#page-8>. Acesso em 27 ago. 2013.

WEIBEL, Peter. El mundo como interfaz. Elementos: Ciencia y Cultura, v. 7, n. 40, p. 2333, 2000. Disponível em <http://www.redalyc.org/articulo.oa?id=29404005>. Acesso em 15 fev. 2013.

WEIBEL, Peter. Architecture: from location to non-location, from presence to absence. In: FLACHBART, G.; WEIBEL, P. (ed). Disappearing Architecture:From Real to Virtual to Quantum. Birkhäuser Verlag, 2005. p. 264-271.

WEISER, Mark. The Computer for the $21^{\text {st }}$ century. Scientific American, September, 1991, p.94-110.

ZIELINSKI, Siegfried. Towards a dramaturgy of differences. V2_Institute for Unstable Media, Rotterdam, Holanda, $1997 . \quad$ Disponível em <http://www.v2.nl/archive/articles/towards-a-dramaturgy-of-differences >. Acesso em 27 out. 2012. 
$m=x+2 y=2$

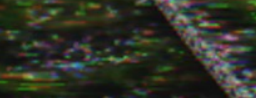

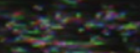

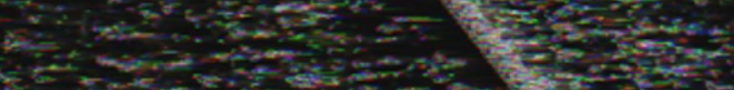

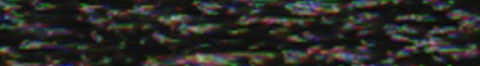

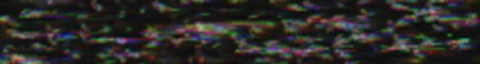
No:

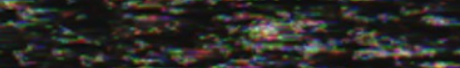

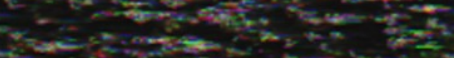
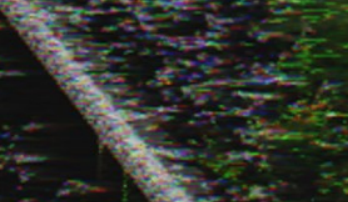

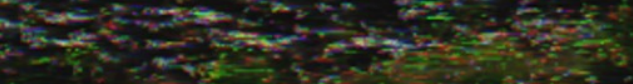
$\Rightarrow 2 x^{2}=2 x$

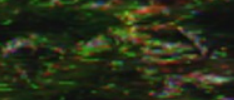

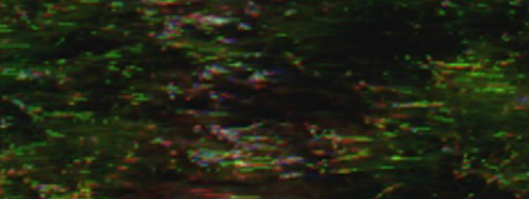

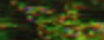

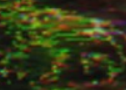

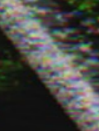

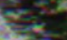

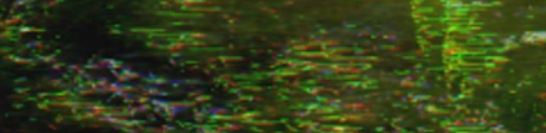
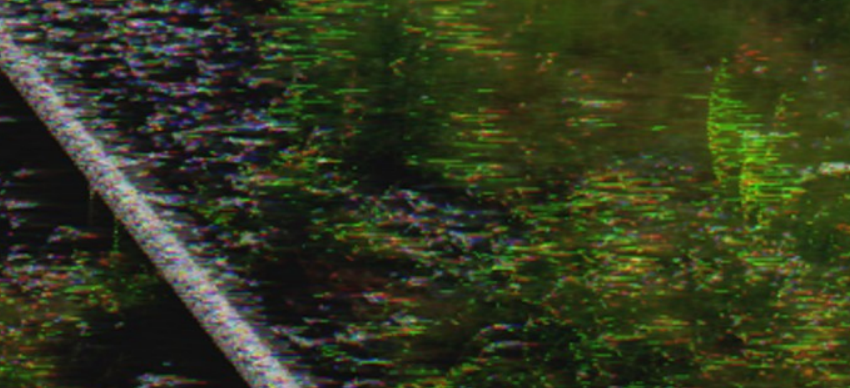

$$
\text { s.t. }
$$

\section{Anexos}





\section{Anexo 01: Créditos do experimento}

\section{Intervenção Reverberação Urbana}

Produção

Luciana Roça

Folheto

Arte: Priscilla Marchetto e Marcelo Tramontano

Texto: Marcelo Tramontano

Pesquisadores Participantes

Cynthia Nojimoto

Denise Mônaco dos Santos

Luciana Santos Roça

Marcelo Tramontano

Mário Henrique Silveira Bueno

Mayara Souza Dias

Priscilla Marchetto

Sandra Soster

Theodoro Monteleone

Varlete Benevente 
Equipe de apoio

Bruno Ribeiro de Oliveira

Emerson Santos

Lucas Leite Raposo

Equipamentos Soundwalk e Captação dos sons do trem

Gravador Marantz PMD 661

Microfone Sennheiser MKH 416

Câmera Canon 1100D 


\section{Anexo 02: Notas sobre imagens}

As imagens dos títulos dos capítulos e a capa da dissertação foram feitas através de recurso conhecido como glitch ou databending.

As imagens foram transformadas em dados brutos e editadas na forma de áudio, também inserindo faixas de áudio referentes aos sons do trem gravados para a intervenção, para serem novamente transformadas em imagem. Em especial, a capa da dissertação consta em uma foto de um prédio do CDHU sobreposta aos sons do trem e a imagem relativa às referências trata-se da representação imagética dos sons do trem.

Trata-se de uma maneira de representar o tema da dissertação, sobrepondo e justapondo som e imagem, além de manipular a imagem como um áudio, editando-o e inserindo efeitos. Dessa forma, espera-se inspirar o leitor em relação ao tema da dissertação através dessas imagens submetidas a esse processo 


\section{Anexo 03: Áudios online}

Os áudios referentes ao experimento podem ser acessados online através do endereço eletrônico

https://soundcloud.com/reverbera-o-urbana 